\title{
Um sistema híbrido inteligente para previsão de posição de átomos de hidrogênio em proteínas
}


Data de Depósito:

Assinatura:

\title{
Um sistema híbrido inteligente para previsão de posição de átomos de hidrogênio em proteínas
}

\author{
Adauto Luiz Mancini
}

Orientadora: Profa. Dra. Roseli Aparecida Francelin Romero

Dissertação apresentada ao Instituto de Ciências Matemáticas e de Computação - ICMC-USP, como parte dos requisitos para obtenção do título de Mestre em Ciências - Ciências de Computação e Matemática Computacional.

USP - São Carlos

Fevereiro/2008 


\section{Agradecimentos}

à minha orientadora, Profa. Dra. Roseli A. Francelin Romero, que sempre me recebeu como a um amigo, contribuiu com muitas sugestões para a pesquisa de técnicas computacionais para serem aplicadas ao problema proposto e pelos incentivos nos momentos dificeis, quando os resultados obtidos estão muito longe do desejado.

à minha mãe, Assumpta, e à minha irmã Tânia, pelo amor incondicional e compreensão dos momentos de ausência dedicados à dissertação.

em memória de meu pai, Laerte. 


\section{Resumo}

Os métodos existentes para a previsão da posição de átomos de hidrogênio em proteínas são todos baseados na simulação computacional de modelos construídos a partir de características físicas e (ou) químicas das moléculas. A abordagem proposta neste trabalho faz uso de técnicas inteligentes para a predição da posição de átomos de hidrogênio contidos em grupos hidroxilas $(\mathrm{OH})$ pertencentes à cadeias laterais dos aminoácidos serina, treonina e tirosina. Estas técnicas inteligentes são utilizadas em duas fases para a solução do problema proposto: o preprocessamento dos dados e a predição da posição do átomo de hidrogênio. $\mathrm{Na}$ fase de preprocessamento, informações sobre os padrões de ligações hidrogênio existentes em moléculas de proteínas são extraídas da base PDB (Protein Data Bank) e reunidas em agrupamentos. A base de dados PDB é a principal base internacional que disponibiliza publicamente a estrutura espacial de biomoléculas, principalmente proteínas e ácidos nucléicos, cujas estruturas espacias foram determinadas através de métodos experimentais. Os padrões de ligações hidrogênio obtidos da base de dados são agrupados por similaridade através de um novo algoritimo proposto, o algoritmo de agrupamento por fusão. Este novo algoritmo de agrupamento foi criado com o propósito de tratar dados com distribuição não uniforme, isolando padrões de entrada muito diferentes da média em agrupamento separados. Após o agrupamento, os padrões de ligações hidrogênio contidos em um grupo têm suas estruturas espaciais superpostas (alinhamento das geometrias dos padrões) através de operações espaciais de translação e rotações, coordenadas pelo uso de um algoritmo genético. Na fase de predição, os padrões já superpostos contidos em cada agrupamento gerado, são utilizados para o treinamento de uma rede neural de arquitetura MLP (multi layer perceptron) para a predição da posição do átomo de hidrogênio contido no padrão. Uma parte dos padrões contidos no agrupamento não são usados para o treinamento da rede e reservados para o teste da capacidade da rede neural inferir a posição do hidrogênio após o treinamento. Para cada agrupamento é treinada uma rede individual, de forma que os parâmetros livres da rede neural sejam calibrados para os dados específicos do agrupamento para o qual a rede neural foi treinada. Após diversas alterações de metodogia ao longo dos experimentos computacionais realizados, a nova abordagem proposta mostrou-se eficaz, com um bom índice de acerto na predição da posição do hidrogênio após o treino da rede neural, para padrões de ligações hidrogênio previamente superpostos em agrupamentos. 


\section{Abstract}

The existing methods for the prediction of the position of hydrogen atoms in proteins are all based on computer simulation models constructed from physical and(or) chemical properties of molecules. The approach proposed in this paper makes use of intelligent techniques for clustering the patterns of hydrogen bonds by similarity, these patterns extracted from the spatial structure of protein molecules, recorded in the files of the PDB (Protein Data Bank). A new algorithm, which allows clustering of data with non-uniform distribution was developed for this purpose. To align spatialy these patterns already grouped in a cluster is used a genetic algorithm that rotates the patterns each other in a way to obtain the aligment of them. The prediction of the position of atoms of hydrogen is done by the training of a MLP (multi layer perceptron) neural network that uses as input the data of the patterns of hydrogen bond contained in a given cluster, previously aligned. The new approach proved to be effective, with a good rate of success in the prediction of the position of hydrogen atoms contained in a cluster after training the neural network. 


\section{Sumário}

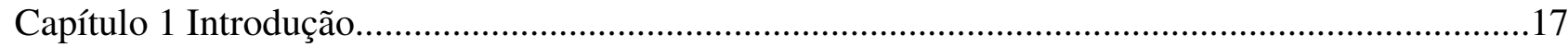

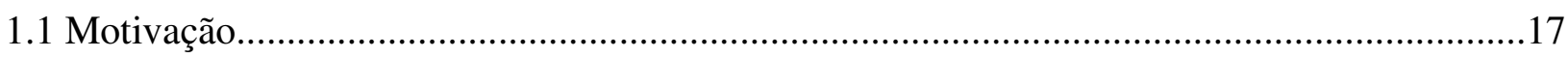

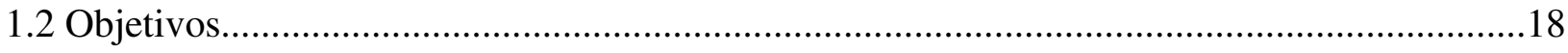

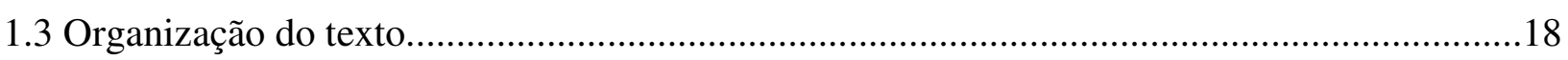

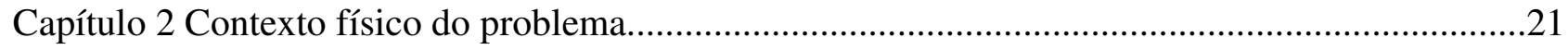

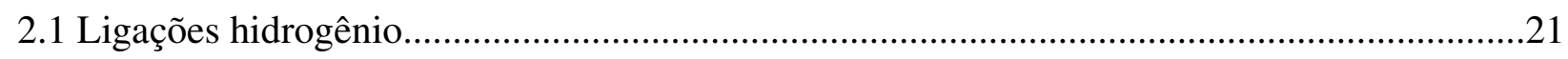

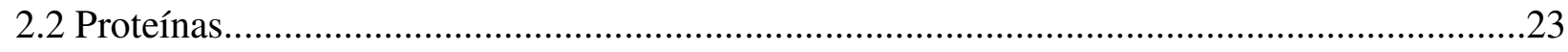

2.3 Determinação da estrutura espacial de biomoléculas.......................................................26

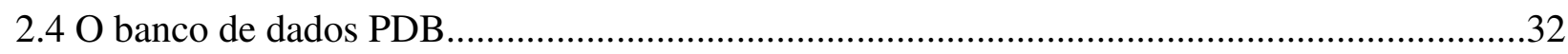

2.5 Métodos existentes para previsão da posição de hidrogênios.................................................32

Capítulo 3 Técnicas inteligentes para reconhecimento de padrões..................................................37

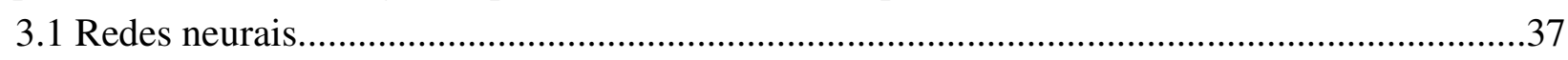

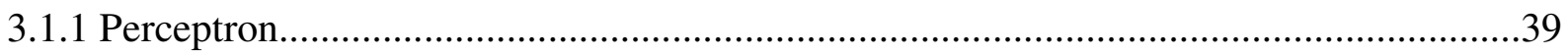

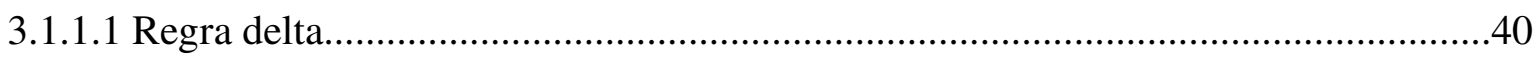

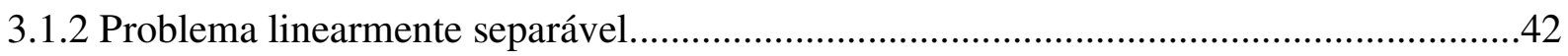

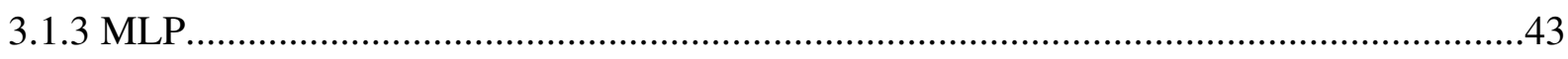

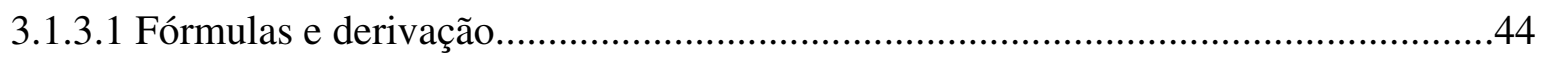

3.1.3.2 Heurísticas para melhorar a convergência........................................................46

3.1.3.3 Generalização e validação.............................................................................. 48

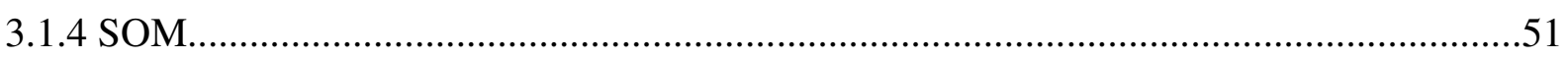

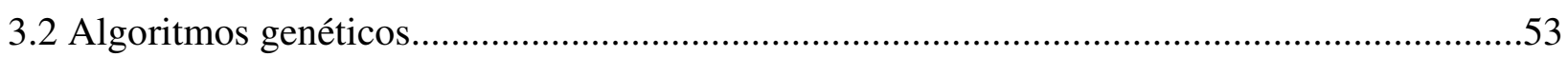

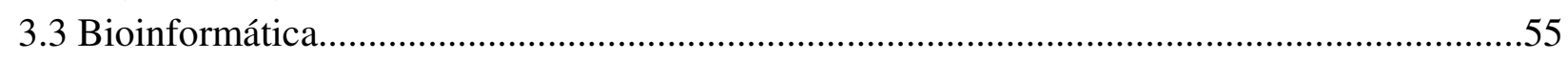

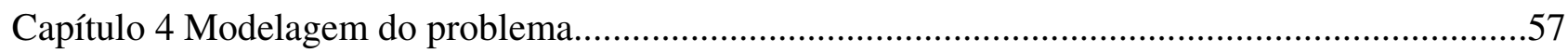

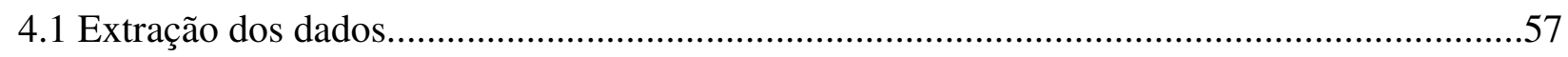

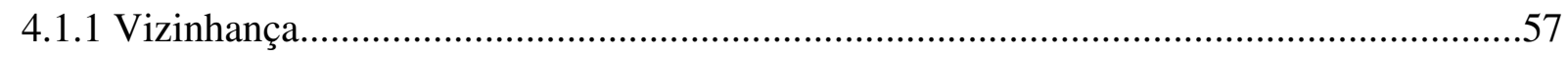

4.1.2 Leitura de dados e geração de padrões de ligações hidrogênio......................................59

4.1.2.1 Grid para mapeamento de átomos próximos.....................................................62

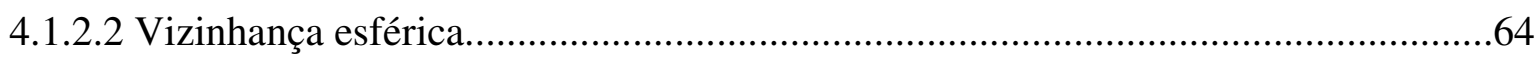

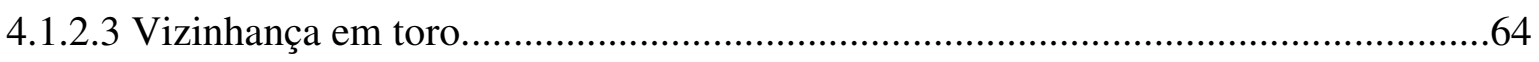

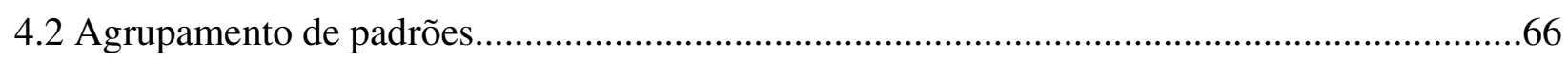

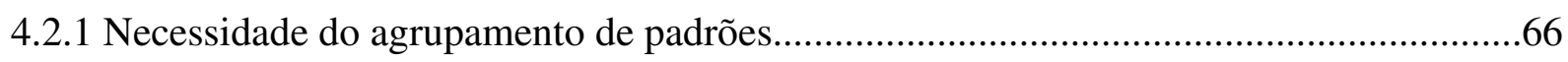

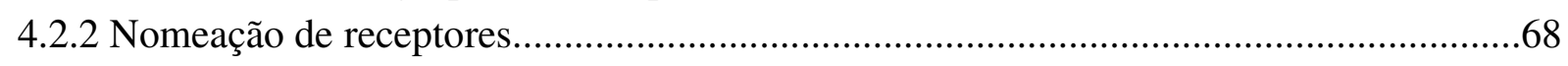

4.2.2.1 Nomeação por projeção escalar........................................................................68

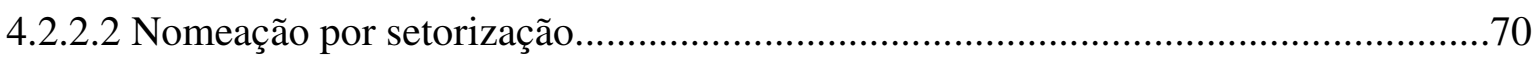

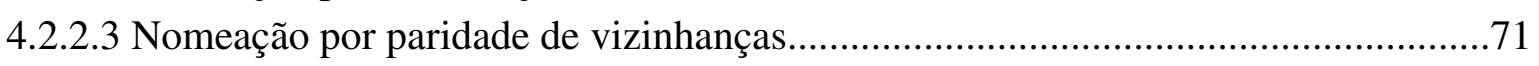

4.2.3 Uso de distância para busca de similaridade entre vizinhanças....................................73 
4.2.4 Agrupamento de vizinhanças com rede neural SOM.................................................75

4.2.5 Agrupamento de vizinhanças por fusão de grupos...................................................76

4.2.5.1 Fusão de grupos em duas fases........................................................................... 79

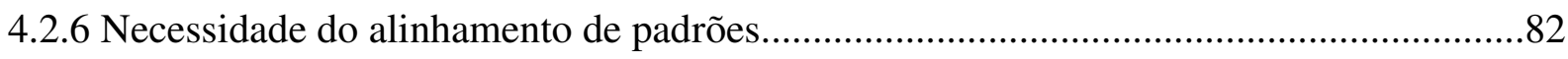

4.2.7 Alinhamento inicial de vizinhanças por translação e rotações........................................82

4.2.8 Ajuste do alinhamento de vizinhanças por AG ........................................................83

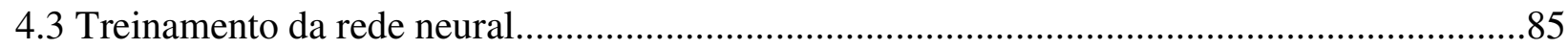

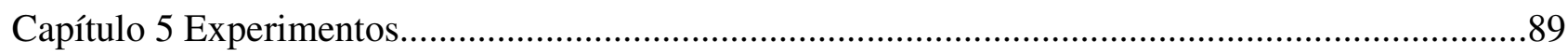

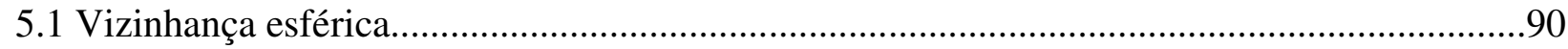

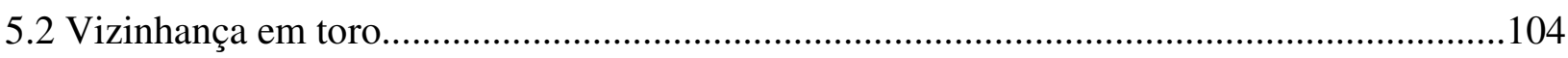

5.3 Vizinhança em toro com fusão de grupos em 2 fases.......................................................114

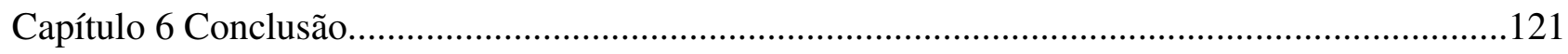

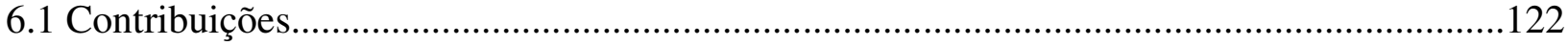

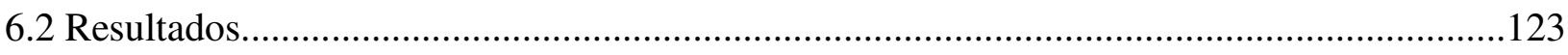

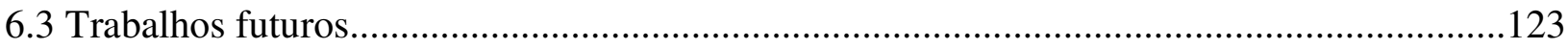




\section{Relação de figuras}

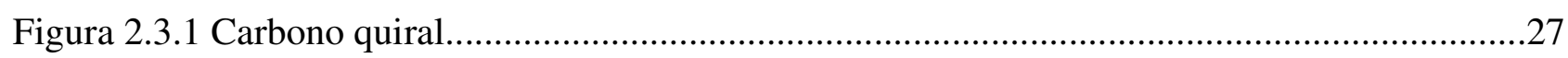

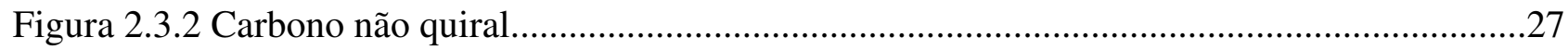

Figura 3.1.1 Dois exemplos de vizinhanças topológicas em duas dimensões, quadrada e hexagonal, para o mapa de Kohonen. O neurônio vencedor, representado no centro, obtém a maior atualização dos pesos enquanto as unidades mais distantes recebem atualizações menores..............................52

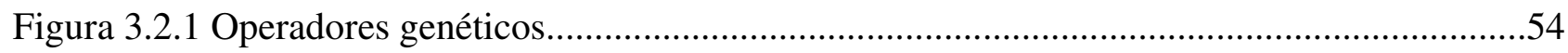

Figura 4.1.1 Vizinhanças nos formatos esfera e toro................................................................59

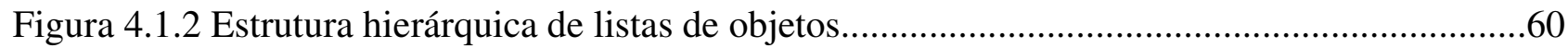

Figura 4.1.3 Grid para indexação espacial de átomos..............................................................63

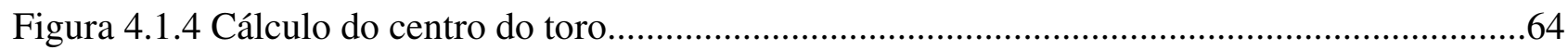

Figura 4.1.5 Plano contendo antecessor, doador e receptor que intercepta o orbital de hidrogênio..65

Figura 4.2.1 Problemas de classificação e aproximação............................................................66

Figura 4.2.2 Regiões da função que possuem amostras de dados a serem aproximadas por redes

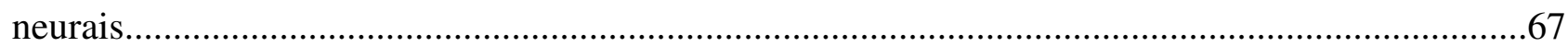

Figura 4.2.3 Nomeação por projeção escalar.........................................................................69

Figura 4.2.4 Nomeação errada de receptores correspondentes por projeção escalar.......................69

Figura 4.2.5 Receptores em um mesmo disco de duas vizinhanças sem correspondência................70

Figura 4.2.6 Divisão do toro em anéis, e de cada anel em setores..............................................70

Figura 4.2.7 Na vizinhança à esquerda o receptor R1 está na trilha 1, setor 3 e o receptor R2 na trilha 2, setor 3. Na vizinhança à direita o receptor R1 está na trilha 2, setor 3 e o receptor R2 na trilha 2, setor 8. Mas fisicamente, os receptor R1 e R2 da vizinhança à esquerda correspondem aos receptores R2 e R1 da vizinhança à direita, respectivamente. Assim houve perda de correspondência da proximidade física entre receptores após a etiquetação..................................71

Figura 4.2.8 Posicionamento de vizinhança para alinhamento simples.......................................72

Figura 4.2.9 Conexão entre os átomos de uma vizinhança representando as distâncias e formando

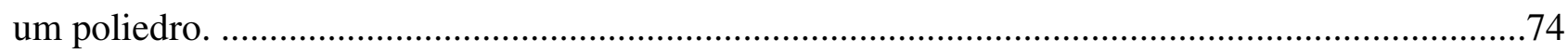

Figura 4.2.10 Duas vizinhanças simétricas com as mesmas distâncias do átomo receptor aos átomos

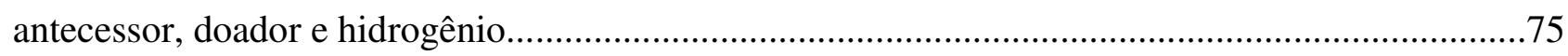

Figura 4.2.11 Alteração na percepção de imagem por movimentos.............................................82 


\section{Relação de tabelas}

Tabela 4.1.1 Relação de aminoácidos com grupo $\mathrm{OH}$ na cadeia lateral (definição de átomos antecessor, doador e hidrogênio seguindo formato PDB).........................................................58

Tabela 4.2.1 Incrementos de rotação para criação de população inicial...........................................84

Tabela 5.1.1 Porcentagem de padrões para treinamento da rede neural........................................91

Tabela 5.1.2 Arquiteturas de rede MLP usadas nos experimentos...............................................91

Tabela 5.1.3 Parâmetros de configuração comuns aos experimentos..............................................92

Tabela 5.1.4 Classificacão de resultados dos experimentos.......................................................93

Tabela 5.1.5 Experimento com vizinhança esférica, um receptor oxigênio, arquitetura 12X12, não

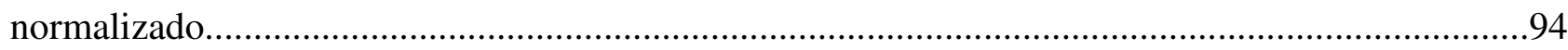

Tabela 5.1.6 Experimento com vizinhança esférica, um receptor oxigênio, arquitetura 12X12, normalizado.

Tabela 5.1.7 Experimento com vizinhança esférica, um receptor oxigênio, arquitetura 24X24, não normalizado.

Tabela 5.1.8 Experimento com vizinhança esférica, um receptor oxigênio, arquitetura 24X24, normalizado.

Tabela 5.1.9 Experimento com vizinhança esférica, um receptor oxigênio, arquitetura 48X12, não normalizado.

Tabela 5.1.10 Experimento com vizinhança esférica, um receptor oxigênio, arquitetura 48X12, normalizado.

Tabela 5.1.11 Experimento com vizinhança esférica, um receptor oxigênio, arquitetura 48X24, não normalizado.

Tabela 5.1.12 Experimento com vizinhança esférica, um receptor oxigênio, arquitetura 48X24, normalizado.

Tabela 5.2.1 Experimento com vizinhança em toro, um receptor oxigênio, arquitetura 12X12, não normalizado.

Tabela 5.2.2 Experimento com vizinhança em toro, um receptor oxigênio, arquitetura 12X12, normalizado.

Tabela 5.2.3 Experimento com vizinhança em toro, um receptor oxigênio, arquitetura 24X24, não normalizado.

Tabela 5.2.4 Experimento com vizinhança em toro, um receptor oxigênio, arquitetura 24X24, normalizado.

Tabela 5.2.5 Experimento com vizinhança em toro, um receptor oxigênio, arquitetura 48X12, não normalizado.

Tabela 5.2.6 Experimento com vizinhança em toro, um receptor oxigênio, arquitetura 48X12, normalizado

Tabela 5.2.7 Experimento com vizinhança em toro, um receptor oxigênio, arquitetura 48X24, não normalizado.

Tabela 5.2.8 Experimento com vizinhança em toro, um receptor oxigênio, arquitetura 48X24, 
normalizado.

Tabela 5.3.1 Experimentos com algorimo de fusão de grupo, com 15 grupos na primeira fase e 50 na segunda fase.

Tabela 5.3.2 Experimentos com algorimo de fusão de grupo, com 30 grupos na primeira fase e 75 na segunda fase. 


\section{Capítulo 1 Introdução}

Os diversos métodos atualmente existentes para a previsão da posição de átomos de hidrogênio em proteínas são majoritariamente baseados na simulação computacional de modelos construídos a partir de regras e restrições obtidos do conhecimento de moléculas. Esta dissertação apresenta uma visão inovadora para o problema de previsão da posição de hidrogênios em proteínas - uma abordagem computacional baseada no agrupamento e reconhecimento de padrões de ligações hidrogênio.

Padrões de ligações hidrogênio podem ser obtidos a partir de dados experimentais, disponíveis em bases de dados de domínio público como o PDB (Protein Data Bank) e o CSD (Cambridge Structural Database) que registram a estrutura espacial de biomoléculas e pequenas moléculas, respectivamente. A abordagem proposta neste trabalho investiga o uso de técnicas inteligentes para:

i. agrupamento dos padrões por similaridade;

ii. superposição espacial dos padrões de ligações hidrogênio (alinhamento das geometrias dos padrões) contidos em um agrupamento;

iii. fazer o reconhecimento de padrões de ligações hidrogênio (de geometrias similares contidas em um agrupamento, previamente superpostas) e predizer a posição dos átomos de hidrogênio em proteínas, através do uso de redes neurais artificiais.

\subsection{Motivação}

A motivação deste trabalho foi o estudo de redes neurais para utilizá-las em aplicações de bioinformática, mais precisamente em aplicações envolvendo o estudo de características espaciais de estruturas protéicas.

Inicialmente desejava-se estudar a região de interface (superfície de contato) de proteínas ligadas a outras proteínas, com o objetivo de dada uma proteína, poder-se prever com quais outras proteínas ela poderia ligar-se. Este problema é complexo e requer muito conhecimento da área de domínio da aplicação para ser modelado, podendo demandar mais tempo que o previsto para a duração de um projeto de mestrado.

Um problema mais simples foi procurado, que não abrangesse um número muito grande de propriedades fisicoquímicas e que fosse passível de ser modelado por alguém que não fosse um especialista na área de domínio da aplicação. O problema encontrado atendendo a estas condições foi o posicionamento de hidrogênios através do 
reconhecimento de padrões de ligações hidrogênio.

A importância de conhecer-se a posição dos átomos de hidrogênio em proteínas é permitir o cálculo, análise e quantificação de propriedades que envolvam componentes espaciais como potencial eletrostático, campos de força, complementariedade de superfícies, volume, determinação da superfície de cavidades e protuberâncias, forças hidrofílicas (e hidrofóbicas) e ligações hidrogênio. Em proteínas, aproximadamente metade dos átomos são do tipo hidrogênio, assim é de grande importância ter-se métodos que permitam posicioná-los quando não houver registro experimental de suas posições.

\subsection{Objetivos}

Os objetivos deste trabalho são:

- pesquisar quais modelos de redes neurais são adequados para agrupar e fazer o reconhecimento de padrões de ligações hidrogênio;

- encontrar um método para fazer a superposição espacial de padrões de ligações hidrogênio;

- implementação de programas para executar os métodos escolhidos;

- realização de experimentos;

- comparação dos resultados obtidos pela nova abordagem com métodos tradicionais.

\subsection{Organização do texto}

No capítulo 2 é apresentada a área de domínio do problema, sendo feita uma revisão dos conceitos fundamentais sobre ligações hidrogênio, estrutura de proteínas e métodos existentes para sua determinação. É apresentada a base de dados PDB, que é a principal base pública contendo informações estruturais sobre proteínas e é feita uma revisão sucinta de alguns métodos existentes para o posicionamento de hidrogênios.

No capítulo 3 são revistos os conceitos sobre redes neurais, com enfoque nos modelos que se acredita serem os mais úteis para o problema proposto: MLP (multi layer perceptron) para reconhecimento de padrões e SOM (self organizing map) para agrupamento de dados. Algoritmos genéticos também são mostrados, porque são uma técnica inteligente que permite a busca paralela em problemas de otimização, percorrendo vários pontos do espaço de solução, geralmente não se prendendo a um único mínimo (máximo) local. Uma breve apresentação da área de bioinformática é feita e do uso de redes neurais em aplicações desta área. 
No capítulo 4 é detalhado como o problema foi modelado em suas várias fases, desde a extração de dados até o treinamento de redes neurais para fazer-se a previsão da posição dos átomos de hidrogênio. É apresentado o conceito de vizinhança, criado para a representação de padrões de ligações hidrogênio. Um algoritmo de grid é proposto para indexar os dados espacialmente e acelerar a recuperação de dados espaciais próximos. Vários métodos para a nomeação de átomos receptores de ligações hidrogênio dentro de uma vizinhança são propostos, com a finalidade de estabelecer a correspondência entre os receptores de uma vizinhança com os receptores de outra vizinhança, as quais estão sendo comparadas por similaridade para posterior agrupamento. $\mathrm{O}$ uso da rede neural SOM para o agrupamento dos dados e os problemas encontrados são apresentados, e como consequência um novo algoritmo de agrupamento é proposto. É mostrado o processo adotado para fazer-se a superposição dos padrões através de algoritmos genéticos e finalmente como a rede neural MLP foi utilizada para fazer-se a previsão dos átomos de hidrogênio.

No capítulo 5 os experimentos realizados são relatados e como os resultados obtidos influenciaram na evolução da modelagem do problema.

No capítulo 6 conclui-se o trabalho com os resultados obtidos e propostas de trabalhos futuros. 
Capítulo 1 Introdução 


\section{Capítulo 2 Contexto físico do problema}

Este capítulo apresenta os principais conceitos físicos (e/ou químicos) relativos ao problema investigado nesta dissertação - a previsão da posição de átomos de hidrogênio em proteínas. Inicialmente, a ligação ${ }^{1}$ hidrogênio e a estrutura básica da composição das proteínas são revistos. A seguir são mostrados sucintamente os métodos existentes para a determinação da estrutura espacial de proteínas. Uma breve citação ao banco de dados PDB é feita, que será utilizado como fonte das informações espacias sobre proteínas para os experimentos a serem apresentados ao longo desta dissertação. No encerramento do capítulo são apresentados os métodos existentes para a previsão da posição de átomos de hidrogênio em estruturas protéicas.

\subsection{Ligações hidrogênio}

Átomos de hidrogênio constituem aproximadamente metade dos átomos encontrados em proteínas [Engler \& Parak, 2003]. As ligações hidrogênio são fundamentais para a formação das estruturas alfa hélice e folha beta, que são padrões conformacionais bem definidos do enovelamento protéico. Alfa hélice e folha beta são dois dos principais elementos que constituem a estrutura secundária das proteínas, junto com os turns. Para uma análise adequada das ligações hidrogênio é desejável saber-se a posição dos átomos constituintes da ponte, porque são aplicados critérios geométricos sobre as posições dos átomos envolvidos na formação da ponte. Assim, saber-se as posições dos átomos de hidrogênio permite um estudo mais completo das forças que mantém a estabilidade protéica.

$\mathrm{Na}$ literatura científica, encontram-se vários artigos publicados sobre ligações hidrogênio nas áreas da química, física e biologia molecular. A ligação hidrogênio, definida em sua forma tradicional, é uma interação entre dois átomos eletronegativos, doador e receptor, através de um átomo de hidrogênio intermediário que é covalentemente ligado ao doador. A densidade eletrônica da ligação átomo doador-hidrogênio é deslocada para o átomo doador, assim uma carga positiva é induzida no átomo de hidrogênio. Esta carga parcial interage com a nuvem eletrônica do átomo receptor. Diferente da ligação covalente, a ligação hidrogênio é uma interação multipolar envolvendo pelo menos três átomos (doador D, receptor R, hidrogênio H) [Torshin et al., 2002].

1 Nesta dissertação será usado o termo ligação hidrogênio (do inglês hydrogen bond), mais moderno, no lugar de ponte de hidrogênio, que é uma expressão que vem entrando em desuso. 
A ligação hidrogênio é uma das mais importantes interações interatômicas no dobramento (folding) de proteínas. Apesar da energia de uma interação média de uma ligação hidrogênio ser pequena $(20 \mathrm{~kJ} / \mathrm{mol})$ quando comparada a uma ligação covalente $(200 \mathrm{~kJ} / \mathrm{mol})$, o fato de haver uma grande ocorrência de ligações hidrogênio tem uma forte influência no dobramento das proteínas. Algumas vezes ela é descrita como a interação que domina o processo de dobramento, apesar que este papel é mais frequentemente atribuído à interação hidrofóbica. Os elementos da estrutura secundária de proteínas são formados essencialmente por padrões de ligações hidrogênio. Consequentemente, ligações hidrogênio têm sido extensivamente estudadas estatisticamente, experimentalmente e teoricamente [McDonald \& Thornton, 1994].

Ligações hidrogênio são classificadas como interações iônicas. Entretanto, diferente de uma ligação covalente, ligações hidrogênio não são caracterizadas por valores específicos de comprimentos de ligação e ângulos, mas pelo uso de intervalos maiores de valores. Em um dos estudos recentes sobre critérios de ligações hidrogênio em proteínas, McDonald e Thornton apresentaram resultados da análise estatística de um conjunto de aproximadamente 50 proteínas [McDonald \& Thornton, 1994]. As seguintes regras empíricas para identificação de ligação hidrogênio foram propostas:

1. $|\mathrm{DR}|<3,9 \AA$

2. $|\mathrm{HR}|<2,5 \AA$

3. $\Varangle(\mathrm{DHR})>90,0^{\circ}$

4. $\Varangle\left(R^{\prime} R D\right)>90,0^{\circ}$

5. $\Varangle\left(R^{\prime} R H\right)>90,0^{\circ}$

onde

$\mathrm{R}$ 'é o átomo antecessor ligado covalentemente ao receptor R;

H é o átomo hidrogênio;

$|X Y|$ é a distância entre os átomos $X$ e $Y$;

$\Varangle(X Y Z)$ é o ângulo em graus entre os átomos $X, Y$ e $Z$;

̊̊ (ångström ou angstrom) é uma unidade de distância correspondente a $10^{-10} \mathrm{~m}$.

Torshin et al. publicaram um trabalho subsequente em que concluem que as regras $2 \mathrm{e}$ 3 são realmente critérios. Nesse artigo é mostrado que a condição da regra 1 é coberta pela regra 2 e portanto redundante, e que as regras 4 e 5 são necessárias apenas em casos de formação anormal da cadeia protéica [Torshin et al., 2002]. 
Um método comumente empregado para modelar ligações hidrogênio é a definição de um campo de força. A definição do campo de força é construída com a aplicação de restrições geométricas às posições dos átomos envolvidos na interação, como ângulos e distâncias, e as fórmulas desenvolvidas para o campo de força produzem como resultado um valor representando a intensidade da ligação hidrogênio. Os trabalhos [Fabiola et al., 2002] e [Kortemme et al., 2002] são exemplos da caracterização de ligações hidrogênio através de campo de força.

\subsection{Proteínas}

Proteínas são as principais móleculas responsáveis pelo funcionamento da maquinaria celular. Uma breve introdução sobre proteínas é apresentada nesta seção provendo o contexto biológico do domínio de aplicação do problema pesquisado.

A bioquímica procura comprender o funcionamento da vida no nível molecular através do estudo da forma e função biológica em termos químicos. Uma das abordagens melhor sucedida para entender os fenômenos biológicos tem sido purificar um componente químico individual, como uma proteína de um organismo vivo e caracterizar sua estrutura química ou atividade catalítica. Entre as perguntas a serem respondidas estão qual a estrutura destas moléculas e quais as forças que estabilizam esta estrutura [Nelson \& Cox, 1982].

Proteínas são as macromoléculas biológicas mais abundantes, ocorrendo em todas as células e em todas as partes das células. Proteínas também apresentam enorme diversidade, mesmo se considerarmos uma única célula: milhares de tipos diferentes, com tamanho variando de relativamente poucos peptídeos até grandes polímeros com massa molecular na casa dos milhões. As proteínas exercem uma enorme variedade de funções biológicas e são o mais importante produto final das vias metabólicas dos seres vivos. A arquitetura celular contém muitos complexos grandes formados das diferentes classes de macromoléculas consigo mesmas ou umas com as outras. Complexos protéicos constituem a maioria dos principais elementos estruturais e locomotores da célula [Turner et al., 2000]. As proteínas exercem as funções de:

- Enzimas - as enzimas são proteínas, excetuando-se umas poucas moléculas de RNA ativas cataliticamente. Enzimas aumentam a velocidade de reações químicas nos seres vivos em várias ordens de magnitude. A ligação (binding) da enzima ao substrato (molécula com que a enzima irá interagir) envolve várias ligações não covalentes da cadeia lateral de aminoácidos específicos incluindo forças de van der Waals, ligações hidrogênio, pontes salinas e forças hidrofóbicas. A especificidade da ligação pode ser extremamente alta, com um único substrato ligante (ex: glucose 
oxidase liga-se apenas à glucose) ou pode ser específica por grupo(ex: hexoquinase liga-se a uma variedade de açucares hexose);

- Sinalização - proteínas receptoras em membranas celulares podem unir-se a ligantes (ex: hormônios) do meio extracelular e por causa da mudança conformacional resultante da ligação, disparar reações na célula em resposta àquele ligante. A ligação ao ligante é similar à ligação ao substrato, mas o ligante usualmente permanece inalterado. Alguns hormônios também são pequenas proteínas, como a insulina e o hormônio do crescimento;

- Transporte e armazenamento - a hemoglobina transporta oxigênio nas células sanguíneas enquanto a transferina transporta ferro ao fígado. Chegando ao fígado, o ferro é armazenado ligando-se à proteína ferritina. Gorduras são carregadas no sangue por lipoproteínas. Através de ligação com proteína muitas outras moléculas e íons são transportadas e armazenadas nos seres vivos. Isto melhora a solubilidade e reduz a reatividade, até que o uso das substâncias armazenadas seja necessário;

- Estrutura e movimento - o colágeno é a principal proteína na pele, ossos e tecido conectivo, enquanto o cabelo é formado principalmente de queratina. Há também muitas proteínas estruturais dentro da célula, como por exemplo no citoesqueleto. As principais proteínas musculares, actina e miosina, formam filamentos deslizantes que são a base da contração muscular;

- Nutrição - a caseína e a albumina são as principais proteínas do leite e ovos, respectivamente, e são usadas para prover os aminoácidos para o crescimento das crias dos animais. Proteínas das sementes também provêm nutrição para os embriões de plantas em germinação;

- Imunidade - anticorpos, os quais reconhecem e ligam-se a bactérias, vírus e outros materiais estranhos ao organismo (o antígeno) são proteínas;

- Regulação - fatores de transcrição ligam-se ao DNA e controlam sua função. Muitas outras proteínas modificam a função de outras moléculas ligando-se a essas moléculas.

Proteínas são os instrumentos moleculares através dos quais a informação genética é expressa de forma funcional. Subunidades monoméricas relativamente simples, os aminoácidos, provêm a chave para a estrutura de milhares de proteínas diferentes. Todas as proteínas são compostas de um mesmo conjunto de 20 aminoácidos, ligados covalentemente em sequências lineares características. Este grupo de 20 moléculas precursoras pode ser considerado como o alfabeto no qual a linguagem das estruturas protéicas é escrita. 
A estrutura da proteína tem a seguinte hierarquia de composição: cadeia, aminoácidos e átomos. A proteína é composta de uma ou mais cadeias de aminoácidos, e cada cadeia é nomeada por um caracter, geralmente uma letra maiúscula, ou por um espaço branco quando houver apenas uma cadeia. A cadeia é uma sequência de aminoácidos unidos consecutivamente um a um através de ligações peptídicas. Os aminoácidos encontrados na natureza são de vinte tipos e compostos por uma parte comum a todos os tipos, a cadeia principal, e por outra parte que os diferencia, a cadeia lateral.

Cada tipo de aminoácido é formado por um conjunto invariante de átomos com ligações covalentes bem determinadas entre os átomos. Assim a estrutura de um aminoácido é relativamente rígida, flexível apenas em alguns pontos em que blocos de átomos ou átomos podem sofrer rotações, como por exemplo alguns hidrogênios da cadeia lateral.

Muitas estruturas macromoleculares são mantidas unidas por um grande número de diferentes interações não covalentes. Interações carga-carga (pontes salinas) atuam entre grupos ionizáveis de carga oposta em um meio com $\mathrm{pH}$ fisiológico, por exemplo entre os fosfatos negativos do DNA e as cadeias laterais positivas lisina e arginina de proteínas de ligação ao DNA, como as histonas. Interações do tipo carga-dipolo e dipolo-dipolo são mais fracas e formam-se quando algum ou ambos os participantes é um dipolo devido à distribuição assimétrica de cargas na molécula. Mesmo grupos sem carga como metil podem atrair-se fracamente através de dipolos transientes resultantes do movimento de seus elétrons (forças de dispersão). Associações não covalentes entre moléculas eletricamente neutras são conhecidas coletivamente como forças de van der Waals. Ligações hidrogênio são de grande importância. Ligações hidrogênio e outras interações envolvendo dipolos têm natureza direcional e assim ajudam a definir a forma macromolecular e a especificidade das interações moleculares. A presença de substâncias sem carga e não polares como os lipídios, em ambiente aquoso, tende a forçar uma estrutura altamente arrumada nas moléculas de água em volta. Isto é energeticamente desfavorável porque reduz a entropia do sistema. Assim, moléculas não polares tendem a agrupar-se, reduzindo a área da superfície exposta à água. Esta atração é denominada interação hidrofóbica e é uma força estabilizante importante em interações proteína-proteína, proteína-lipídio e em ácidos nucléicos [Turner et al., 2000].

Um dos aspectos mais importantes para o estudo de ligações hidrogênio é a geometria dos átomos envolvidos, assim é necessário conhecer-se a posição dos átomos componentes da ponte. Hidrogênios podem ser localizados em proteínas principalmente através dos métodos NMR (ressonância nuclear magnética) e cristalografia de neutrons [Shu et al., 2000], mas atualmente comparativamente poucas estruturas foram resolvidas por neutron. Resolver uma estrutura significa determinar os átomos constituintes da 
estrutura e suas posições espaciais, através de métodos laboratoriais. A principal base de dados pública de estruturas biomoleculares, o PDB (Protein Data Bank) [Berman et al., 2000], acessível via web no endereço http://www.rcsb.org/pdb (acessado em 18/12/2007), registra o valor de 6008 estruturas protéicas resolvidas pelo método NMR e 37814 pelo método difração de raio-x, estatísticas válidas para a data de 11 de dezembro de 2007. Conforme podemos observar por estes números, o método de difração por raio-x é o mais empregado, mas as posições dos átomos de hidrogênio são determinadas por este método apenas quando a resolução é muito alta (abaixo de 1,5 $\AA$, quanto menor o valor mais alta a resolução). Do total das estruturas resolvidas por cristalografia de raios-X ou microscopia de elétrons, apenas $298(0,73 \%)$ estruturas têm resolução entre 0,5 e 1,0 Å; e $3219(7,93 \%)$ estruturas têm resolução entre 1,0 e $1,5 \AA$.

\subsection{Determinação da estrutura espacial de biomoléculas}

O surgimento de tecnologias, a partir da década de 1950, capazes de identificar a composição e o formato de proteínas permitiu aos cientistas estudar o funcionamento celular no nível molecular. O conhecimento da estrutura espacial de uma biomolécula é necessário para a compreensão das interações físicas e químicas da biomolécula com outros átomos e moléculas (orgânicas ou não) nos seres vivos. Para estas interações ocorrerem, além da complementariedade das características fisicoquímicas, é necessária também uma complementariedade espacial das estruturas na interface das moléculas. A interface é a área de contato das superfícies das moléculas envolvidas. A complementariedade espacial permite a aproximação adequada dos grupos químicos de cada molécula de forma a permitir a interação. Esta complementariedade química e espacial confere especificidade ao funcionamento da biomolécula, isto é, restringe a quantidade de outras substâncias com as quais a biomolécula consegue interagir.

Podemos pensar na estrutura espacial de uma biomolécula em termos de configuração e conformação. Configuração refere-se às limitações de possibilidades do arranjo espacial dos átomos de uma biomolécula em função da presença de ligações covalentes duplas, que não permitem rotação entre os átomos que compõem a ligação no eixo contido pela ligação, ou da presença de centros quirais (chiral center) em torno dos quais grupos químicos são posicionados em uma sequência específica. Um centro quiral é um átomo de carbono que é ligado a quatro grupos químicos distintos, um em cada uma das quatro ligações covalentes do átomo. Neste caso, as quatro ligações covalentes são simples e distribuem-se espacialmente do centro para as pontas de um tetraedro, sendo que o átomo de carbono fica no centro do tetraedro. Em um centro quiral, quando se fixa uma das ligações e escolhe-se um dos outros três grupos associados como referência, a identificação 
dos grupos no sentido horário é distinta da identificação no sentido anti-horário, não permitindo simetria espacial (porque não há grupos repetidos) quando fixada uma das ligações. As figuras 2.3.1 e 2.3.2 ilustram a diferença entre um carbono quiral e um não quiral (com o grupo G2 repetido) considerando como fixa a ligação entre C e G4 [Nelson \& Cox, 1982].
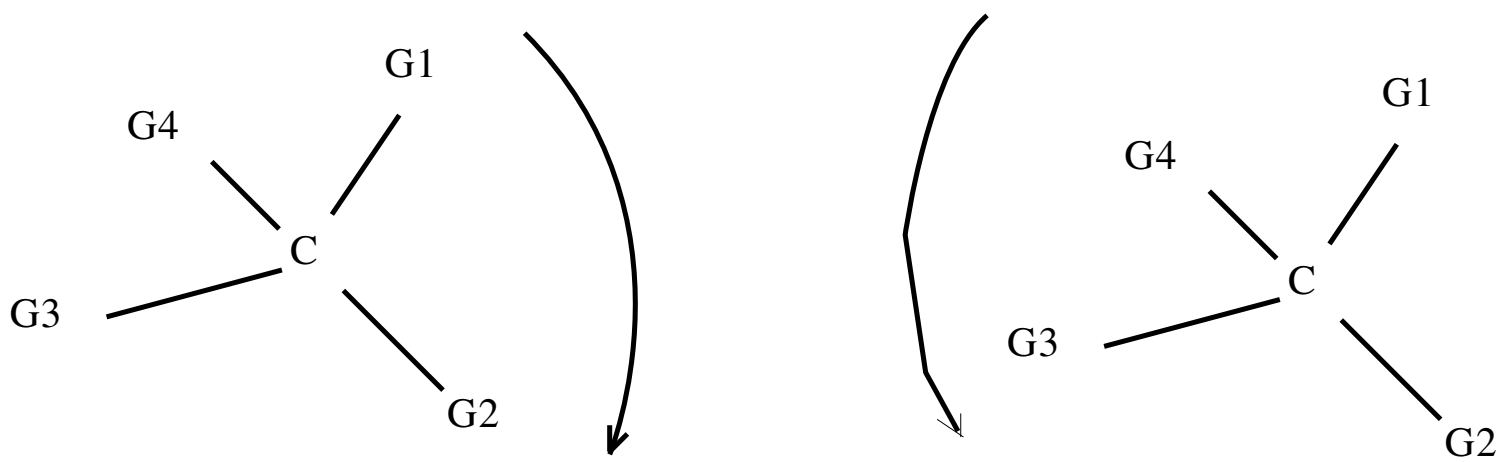

Carbono quiral(assimétrico)

sentido horário: $\mathrm{g} 1, \mathrm{~g} 2, \mathrm{~g} 3$

sentido antihorário: $\mathrm{g} 1, \mathrm{~g} 3, \mathrm{~g} 2$

Figura 2.3.1 Carbono quiral.
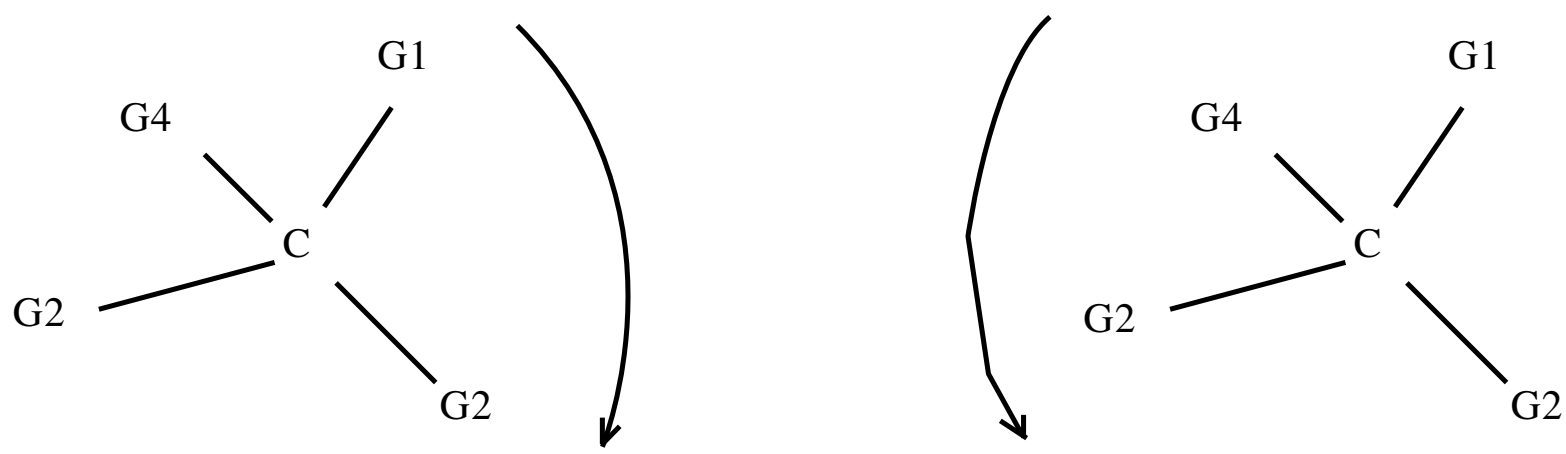

Carbono não quiral(simétrico)

sentido horário: g1,g2,g2

sentido antihorário: g1,g2,g2

Figura 2.3.2 Carbono não quiral.

Conformação molecular refere-se aos vários formatos que uma molécula pode assumir em vários pontos permitidos pela liberdade de rotação dos grupos químicos 
componentes em redor do eixo de uma ligação atômica simples [Glusker et al., 1994]. Teoricamente existem muitas possibilidade para estas rotações, dado que uma proteína contém centenas de ligações simples, mas umas poucas configurações predominam sob as condições biológicas no mundo real. Esta(s) conformação(ões) resultante(s) é(são) a(s) que apresenta $(\mathrm{m})$ maior estabilidade termodinamicamente, tendo a menor energia livre de Gibbs (G). Proteínas em suas conformações funcionais são chamadas proteínas nativas [Nelson \& Cox, 1982].

Pasteur foi um dos primeiros cientistas a percerber a importância da forma tridimensional das moléculas biológicas. Ele manualmente separou cristais com formatos diferentes de ácido tartárico racêmico e observou que as diferenças na forma refletiam diferenças da constituição química. Posteriormente Pasteur observou que durante a fermentação do ácido tartárico as enzimas reagiam de modo seletivo, em função da forma, com apenas um dos dois formatos do ácido tartárico que ele havia obtido [Lesk, 2001].

Fischer mostrou que proteínas eram compostas por aminoácidos ligados consecutivamente em uma cadeia linear e também percebeu a importância da estrutura para a seletividade de enzimas, a habilidade de discriminar entre moléculas muito similares, descrevendo o comportamento como uma relação de chave e fechadura, em que apenas a chave certa abre determinada fechadura [Lesk, 2001].

Durante o século XIX, alguns cientistas tentaram deduzir a estrutura molecular de algumas substâncias formulando teorias desenvolvidas a partir do estudo visual do formato obtido de alguns cristais. Porém, as dimensões envolvidas no mundo molecular, na ordem de grandeza do Ångström $\left(1 \AA=10^{-10} \mathrm{~m}=10^{-8} \mathrm{~cm}\right)$, estavam além das tecnologias disponíveis na época, não podendo sequer serem sensibilizadas através da luz visível em microscópios. Em 1912, von Laue descobriu a difração de raio-X por cristal. W.L. Bragg teve a idéia de que a difração poderia ser usada para a determinação do arranjo atômico em cristais [Glusker et al., 1994]. Em 1913, Braggs resolvia a estrutura de minerais simples como sal de rocha. No mesmo ano, Nishikawa e Ono obtiveram fotografias de difração de raio-X da seda e concluiram que o material apresentava algum tipo de estrutura ordenada no nível molecular. $\mathrm{O}$ estudo subsequente de fibras protéicas por padrões de difração de raio-X despertou grande interesse. Materiais fibrosos como cabelo e seda apresentam em sua estrutura formas simplificadas arquétipas dos principais elementos estruturais das proteínas globulares: folhas e hélices. A solução de estruturas fibrosas por difração era um trabalho relativamente simples para a obtenção de modelos estruturais destas moléculas. Mudanças foram necessárias com a solução das primeiras proteínas globulares por cristalografia de raio-X - mioglobina e hemoglobina, seguidas por lisozima e quimotripsina 
- que apresentaram dificuldades muito maiores [Lesk, 2001].

Uma das principais dificuldades encontradas foi o problema da fase, que consistia na inabilidade de medir-se diretamente as fases das ondas da radiação. Durante anos, Perutz pacientemente tentou resolver este problema de diferentes modos, alguns dos quais excessivamente trabalhosos para poderem tornar-se úteis. De certa forma, nascia a biologia estrutural com a descoberta de Perutz de um método para faseamento: o método de substituição isomórfica múltipla - MIR (Multiple Isomorphous Replacement). Neste método, a informação para determinação da fase é conseguida observando-se o efeito da adição de átomos pesados em posições bem definidas do cristal da estrutura. O termo isomorfo refere-se ao fato de que cristais nativos e cristais adicionados com átomos pesados, apresentam a propriedade de terem as mesmas dimensões para a célula unitária. A célula unitária é a estrutura repetitiva da molécula no cristal, empilhada em grade. O tamanho da célula unitária e a orientação da molécula na proteína não podem variar ao longo do cristal para que não haja ruído nos dados obtidos para a determinação da estrutura. Com o método MIR, os cristais da estrutura nativa e da estrutura aditivada de metais pesados diferem somente pela presença dos metais pesados. Trabalhando juntos, Perutz e Jonh Kendrew conseguiram resolver a estrutura da mioglobina $(\mathrm{Mb})$ na década de 1950. Com os dados obtidos da difração de raio-X e o método MIR, as estruturas cristalinas da hemoglobina e mioglobina foram resolvidas com resolução de 5.5 e $2.8 \AA$, respectivamente. Perutz e Kendrew ganharam o prêmio Nobel em 1962 por seus trabalhos pioneiros [Banaszak, 2000].

O desenvolvimento da cristalografia, iniciada com o uso de raios- $X$, permitiu o estudo do fenômeno físico da difração usando outras formas de radiação como elétrons e neutrons. Estes métodos foram aplicados a materiais cristalinos, fibras e outros vetores bidimensionais. $\mathrm{O}$ ramo envolvendo raios-X e cristais é o mais importante porque tais experimentos geralmente conduzem à determinação da estrutura tridimensional das proteínas. Materiais paracristalinos como fibras também podem ser usados para obter-se informação estrutural. Análises envolvendo estes materiais são mais difíceis do que os que formam um cristal único. Mesmo assim, métodos de difração foram usados com sucesso para o estudo de proteínas fibrosas, vírus afinados longos com formato de haste e DNA [Banaszak, 2000].

A cristalografia de raio- $X$ foi por muitos anos a única fonte detalhada para obtenção de estruturas macromoleculares (moléculas de grande porte) até que nos anos $1980 \mathrm{~K}$. Wuthrich e R. R. Ernst desenvolveram métodos para solucionar estruturas protéicas pela espectroscopia de ressonância nuclear magnética - NMR (Nuclear Magnetic Resonance spectroscopy). Cristalografia de raio-X e NMR são as duas técnicas principais para a 
determinação de estruturas de proteínas, responsáveis pela maioria das estruturas conhecidas, exceto umas poucas resolvidas por outros métodos [Lesk, 2001]. Como o método NMR permite a análise de macromoléculas em solução, que é o estado físico mais próximo das proteínas no meio fisiológico, e os resultados obtidos não apresentaram diferenças conformacionais significativas com os obtidos por cristalografia, finalmente pode-se validar a cristalografia como um método confiável porque havia a dúvida se o empacotamento das macromoléculas em cristais não gerava alterações estruturais em relação ao formato no meio "in vivo" [Banaszak, 2000].

A difração por neutron tem sido empregada para a localização precisa de átomos de hidrogênio em proteínas cristalizáveis. Uma das dificuldades deste método é que o pesquisador precisa ter acesso a um reator nuclear [Banaszak, 2000]. Este método tem proporcionado em alguns casos detalhes sobre átomos de hidrogênio cruciais e a identificação sem ambiguidade de moléculas de água [Lesk, 2001]. Por causa do baixo poder de espalhamento para raio-X, hidrogênios normalmente não são localizados pela cristalografia de raio-X em macromoléculas, exceto nos laboratórios que possuam aparelhagem capaz de trabalhar com resolução muito alta. Os raios-X são difratados por elétrons e as coordenadas atômicas, refinadas dos dados experimentais obtidos pela cristalografia, fornecem o centro da distribuição de elétrons ao redor de cada átomo. $\mathrm{O}$ fato do hidrogênio possuir um único elétron dificulta sua determinação por raio-X. Nos átomos de hidrogênio e nos orbitais híbridos $\mathrm{sp}$ de certos átomos, o centro da distribuição de elétrons é deslocado significativamente do núcleo atômico, de forma que os comprimentos de ligação obtidos pela cristalografia de raios-X não correspondem aos valores reais. Como os neutrons difratam o núcleo atômico, produzem um valor mais próximo do valor correto para comprimento de ligação envolvendo átomos de hidrogênio [Glusker et al., 1994].

A dispersão de neutrons por átomos de hidrogênio ou deutério é comparável à dispersão de neutrons por outros tipos de átomos. Entretanto, a intensidade dos neutrons é várias ordens de magnitude mais fraca que a fonte de raio-X de um laboratório típico, mesmo considerando as fontes de neutrons mais poderosas existentes atualmente. Isto implica na necessidade dos pesquisadores conseguirem produzir cristais grandes, com volume superior a $1 \mathrm{~mm}$ cúbico, para produzir reflexões da fonte de neutrons suficientemente fortes para poderem ser detectadas. O tempo de exposição dos cristais à fonte é longo, na ordem de dezenas de minutos por ângulo de rotação do cristal, fazendo com que o tempo de coleta de informações demore semanas ou meses [Glusker et al., 1994].

Como aproximadamente metade dos átomos de uma proteína são do tipo hidrogênio, obter-se a medida das reflexões mais fracas torna-se difícil, ou impossível, uma vez que a proteína é um sistema de difração fraco, podendo haver um fundo de dispersão incoerente 
(algumas difrações apresentam fases de ondas complementares produzindo um efeito de anulação na sensibilização do dispositivo de recepção), resultado de ruído da grande quantidade de átomos de hidrogênio presentes. Outra dificuldade encontrada no método é que o comprimento de dispersão coerente do hidrogênio é negativo, enquanto que o comprimento dos outros átomos é positivo. Esta diferença de sinais conduz ao cancelamento da observação de algumas medidas no conjunto. Este problema tem sido parcialmente contornado com a substituição, quando possível, de átomos comuns de hidrogênio por deutério $^{2}$, que apresenta sinal positivo [Shu et al., 2000].

R. Henderson e colegas determinaram a estrutura da bacteriodopsina estabelecendo a difração de elétrons como um método para a solução de estruturas de membranas protéicas que formam vetores regulares bidimensionais [Lesk, 2001]. Difração de elétrons tem permitido obter-se imagens bidimensionais de baixa resolução obtidas de cristais bem finos. Como cada micrografia de elétron é bidirecional, muitas imagens são necessárias para se reconstruir o modelo 3-D da estrutura pesquisada. O processamento digital das micrografias de elétrons apresenta como vantagens a possibilidade de correções de astigmatismo e foco [Banaszak, 2000].

Microscopia de elétrons a baixa temperatura (cryo-EM) tem permitido estudos estruturais de grandes agregados macromoleculares, que podem ser muito difíceis de serem preparados como cristais únicos, adequados para cristalografia. Microscopia de elétrons de espécimes congelados à temperatura do nitrogênio líquido tem revelado a estrutura de associações de macromoléculas na faixa de 100 a $1500 \AA$ de diâmetro, como o núcleo do vírus da hepatite B. Por causa da baixa resolução, o resultado é visto como aglomerados ao invés de átomos individuais. Em alguns casos entretanto, quando consegue-se uma melhor resolução, na casa dos 3 a 4 A , é possível determinar blocos da estrutura secundária do conplexo, como folhas e hélices. Combinando-se a utilização dos resultados da microscopia de elétrons, que permite o estudo de grandes agregados macromoleculares, com os resultados da cristalografia, com resolução molecular aplicados a segmentos menores isolados do complexo, torna-se possível obter um mapeamento do modelo atômico completo de toda a montagem do complexo com alta definição [Lesk, 2001].

Dispersão de raio-X com pequenos ângulos ( $S A X S$ - small angle X-ray scattering) e dispersão de neutron com pequenos ângulos (SANS - small angle neutron scattering)

$2 \mathrm{O}$ deutério é um dos isótopos estáveis do hidrogénio (símbolo $2 \mathrm{H}$ ). $\mathrm{O}$ núcleo do deutério é formado por um próton e um neutron. Ainda que não seja um elemento no sentido estrito (é hidrogênio) pode ser simbolizado pela letra D. O seu peso atômico é igual a 2. Encontra-se na natureza na proporção de um para cada 7.000 átomos de hidrogênio. 
permitem a difração de raios-X e neutron, respectivamente, por moléculas de proteínas em solução. Quando em solução, as moléculas de proteínas precipitam-se rapidamente em relação à escala de tempo em que as medidas sobre as difrações são obtidas. Os dados estruturais são conseguidos calculando-se uma média esférica ${ }^{3}$ dos dados obtidos. Se o formato da molécula é aproximadamente esférico, o tamanho pode ser obtido com bastante acuracidade. Caso contrário, ainda é possível obter-se informações sobre o formato da molécula, mas com grande dificuldade em geral. Quando a macromolécula é um complexo, isto é, apresenta mais de um componente, como por exemplo proteína e ácido nucléico, alguma informação pode ser obtida a respeito da distribuição radial ${ }^{4}$ dos componentes. Os resultados são obtidos somente com baixa resolução e o método SANS presta-se melhor para isto (estudo de complexos). $\mathrm{O}$ uso de neutrons envolve o uso criterioso de $\mathrm{H}_{2} \mathrm{O}$ e $\mathrm{D}_{2} \mathrm{O}$ porque os átomos de hidrogênio e deutério difratam os neutrons de forma diferente, conforme citado no método de cristalografia de neutron [Banaszak, 2000].

\section{$2.4 O$ banco de dados PDB}

O material a ser usado para os experimentos serão os arquivos textos da base de dados PDB(http://www.rcsb.org/pdb) [Berman et al., 2000], para estruturas resolvidas pelos métodos NMR, cristalografia de raio-X com alta resolução e cristalografia de neutron. Conforme já citado no capítulo 1, o PDB é o principal banco de dados publicamente disponível que armazena a estrutura espacial de biomoléculas, principalmente de proteínas. Um arquivo pdb de uma estrutura resolvida pelo método NMR apresenta vários modelos para a estrutura. Cada modelo apresenta o mesmo conjunto de átomos constituintes da estrutura, mas há pequenas variações nas posições espaciais dos átomos, quando comparado com outro modelo. Proteínas resolvidas por métodos de cristalografia registram um único modelo para a estrutura.

\subsection{Métodos existentes para previsão da posição de hidrogênios}

A adição de átomos de hidrogênio em estruturas de proteínas determinadas experimentalmente ou em modelos criados empiricamente, que contêm somente átomos não hidrogênio é um passo comum para o refinamento de estrutura cristalográfica, em estudos teóricos de proteínas e em previsão de estrutura protéica. A previsão acurada das posições

3 A média esférica de uma função $u$ é a média dos valores $u(y)$ com $y$ pertencente a uma 'esfera' de dado raio centrada em determinado ponto $y$.

4 Em mecânica computacional e mecânica estatística, a função distribuição radial $g(r)$ descreve como a matéria no entorno varia como uma função da distância de um dado ponto. 
de hidrogênio é essencial, desde que constituem aproximadamente metade dos átomos em proteínas e contribuem significativamente para o equilíbrio de suas energias. $\mathrm{O}$ posicionamento correto de átomos de hidrogênio é necessário para o estudo detalhado da função de uma proteína. Várias metodologias são disponíveis para posicionar hidrogênio em modelos de proteínas de átomos pesados. Algumas destas são softwares individuais, como MCCE, enquanto outras são componentes de pacotes maiores, como CHARMM, CNS, GROMACS, MolProbity, WHAT IF e X-PLOR. Estas ferramentas utilizam diferentes algoritmos para gerar modelos iniciais, e incorporam uma variação de funções de energia empíricas e fisicoquímicas, e em alguns casos refinamento adicional através de protocolos de minimização de energia . Abaixo é mostrada uma breve descrição destes programas:

- "GROMACS - um método baseado em geometria, usando diferentes comprimentos de ligações e ângulos de acordo com o campo de força selecionado. Átomos de hidrogênio de moléculas de água são previstos pelo posicionamento das ligações O$\mathrm{H}$ alternadamente ao longo dos 3 eixos das coordenadas, em ambas direções. A função de energia inclui termos para as interações van der Waals, Coulomb e energia de ligação. GROMACS otimiza os estados de protonação da histidina tentando satisfazer as ligações hidrogênio vizinhas [Forrest \& Honig, 2005]."

- "Hbuild - um algoritmo de busca sistemático, usado nos pacotes de software CHARMM e X-PLOR, os quais testam as posições de hidrogênio em intervalos de $10^{\circ}$ ou $3^{\circ}$ graus ao redor de um eixo de um cone de lado igual ao comprimento da ligação. As exceções são os hidrogênios do tipo $\mathrm{CH}-, \mathrm{NH}-, \mathrm{pCH}-$ e pNH, os quais são posicionados geometricamente. Hidrogênios são posicionados sequencialmente em todos os aminoácidos seguidos de todas as moléculas de água, com as moléculas de água mais próximas à proteína consideradas primeiro. Hidrogênios das águas são posicionados em direção aos receptores de ligações hidrogênio vizinhos; se não houver nenhum as pontes $\mathrm{O}-\mathrm{H}$ são posicionadas ao longo dos eixos das coordenadas. A função de energia inclui energias para van der Waals, Coulomb e ângulos de torção. O termo de energia ligação hidrogênio originalmente descrito não é mais implementado. Comprimentos e ângulos de ligações dependem de qual campo de força foi usado, CHARM19 ou CHARM22; no último, todos os hidrogênios são descritos explicitamente, enquanto no primeiro muitos hidrogênios não polares são tratados como "unidos" com seu respectivo átomo de carbono [Forrest \& Honig, 2005]."

- "CNS - usando o script generate.inp em CNS, os hidrogênios são posicionados aleatoriamente inicialmente, e são otimizados usando 4 estágios de simulação de dinâmica molecular, alternadamente com 5 estágios de minimização de energia 
Powell com até 500 passos por iteração. O campo de força é uma versão adaptada de PARALLHDG e PARHCSDX11, os quais incorporam os parâmetros de ligação e ângulos de Engh e Huber. O arquivo com os parâmetros do campo de força inclui termos van der Walls e ligação, mas não inclui interações Coulomb, consistente com os procedimentos padrões de refinamento de estrutura em cristalografia de raios-X. Entretanto, CNS é capaz de calcular interações Coulomb se for providenciado um arquivo adequado de parâmetros de campo de força [Forrest \& Honig, 2005]."

- "MCCEf - este é o estágio inicial rápido do MCCE para o qual energias de solvação (de distribuição do solvente, geralmente água no meio fisiológico, nas moléculas consideradas) geralmente não são computadas. Átomos protéicos de hidrogênio não hidroxila são adicionados usando geometrias padrões (comprimento de ligação 1,0 $\AA, 109^{\circ}$ graus para grupos tetraédricos) enquanto hidrogênios de águas e hidroxila são testados em intervalos de $10^{\circ}$ graus usando uma busca sistemática. Monte Carlo é então utilizado para encontrar as conformações de mais baixa energia dos múltiplos hidrogênios vizinhos, usando um termo Coulomb com valor 4 para a constante dielétrica [Forrest \& Honig, 2005]."

- "MCCE - hidrogênios não hidroxila são obtidos da saída do MCCEf, e são baseados em geometria. Para posicionar hidrogênios hidroxila e de água, MCCE testa a energia mínima do ângulo de torção, bem como as potenciais posições dos receptores vizinhos de ligações hidrogênio. Um procedimento Monte Carlo é então usado com a seguinte função de energia: termos torção CHARM22 modificada e van der Walls relaxado, e energia de solvação e emparelhamento eletrostático do software Delphi [Forrest \& Honig, 2005]. “

- "MolProbity - um método heurístico que usa pontos de contato de superfícies para otimizar redes locais de ligações hidrogênio e sobreposições de van der Waals. Hidrogênios não polares, exceto grupos $\mathrm{CH} 3$ de metioninas e tipos $\mathrm{NH}$, pNH e pNH2 são posicionados geometricamente; os comprimentos de ligação são $1,1 \AA$ (ligações C-H) ou 1,0 Å (ligação N-H) para grupos $\mathrm{OH}$, orientações em direção aos receptores de ligações hidrogênio são testadas (com comprimento de ligação de 1,0 ̊), assim como posições distantes $15^{\circ}$ e $30^{\circ}$ graus tomadas a partir destas, dependendo da distância do contato. Uma posição adicional com mínimo de contatos é adicionada a estas, e todas as opções são ranqueadas. Finalmente, a primeira posição local do ranque é escolhida como a posição de energia mais baixa. Estados de protonação da cadeia lateral da histidina são escolhidos para otimizar os padrões de ligações hidrogênio. Em adição, MolProbity tem a capacidade de testar orientações 
alternativas das cadeias laterais de histidina, asparagina e glutamina [Forrest \& Honig, 2005]."

- "WHAT IF - uma função de energia estatística empírica, combinada com um conjunto de heurísticas, é usada para otimizar redes locais não interconectadas de ligações hidrogênio. Posicionamento geométrico (usando comprimentos de ligação de $1,0 \AA$ e ângulos tetraédricos de $109,5^{\circ}$ graus) é usado para grupos não rotacionais e para hidrogênios $\mathrm{CH} 3$. Para hidrogênios $\mathrm{NH} 3$ e $\mathrm{OH}$, as posições do hidrogênio são testadas em intervalos de $10^{\circ}$ graus em volta do eixo de um cone. Para moléculas de água, 366 orientações diferentes são testadas. Para determinar as redes ótimas, WHAT IF testa os diferentes estados de protonação e incorpora interações de moléculas simetricamente relacionadas [Forrest \& Honig, 2005]." 
Capítulo 2 Contexto físico do problema 


\section{Capítulo 3 Técnicas inteligentes para reconhecimento de padrões}

Este capítulo faz uma revisão dos modelos de redes neurais perceptron, SOM (self organizing map), MLP (multi layer perceptron) e de algoritmos genéticos, que serão utilizados para a modelagem do problema. Também é dada uma introdução sobre o que vem a ser bioinformática, a área de aplicação do problema investigado, e exemplos de uso de redes neurais neste domínio do conhecimento.

\subsection{Redes neurais}

Redes neurais artificiais (RNA) pertencem à classe adaptativa da área de aprendizagem de máquina. Outros nomes também usados para designar o domínio de redes neurais incluem conexionismo, processamento distribuído paralelo (PDP), computação neural, redes adaptativas e computação coletiva [Russell \& Norvig, 2004] [Bittencourt, 1996]. Este campo é uma das duas grandes linhas da inteligência artificial (IA), ao lado da linha simbólica, e tem por objetivo investigar a possibilidade de simulação de comportamentos inteligentes através de modelos baseados na estrutura e funcionamento do cérebro humano [Bittencourt, 1996].

Como sabemos, um neurônio é uma célula do cérebro que coleta, processa e difunde sinais elétricos. A formação de extensas e complexas redes de neurônios é uma das principais responsáveis pela capacidade de processamento de informações do cérebro. Mesmo tendo surgido na mesma época, as técnicas simbólicas de IA baseadas na lógica foram preferidas no início. Algumas razões para isto foram a falta de computadores potentes na época para processar a grande quantidade de cálculos exigida pelo método e a publicação do livro Perceptrons, de Minsk e Papert (1969), que mostrava limitações ao conexionismo, como a impossibilidade de simular o operador "ou-exclusivo" com uma única camada de neurônios perceptrons (uma forma simples de rede neural). Na década de 80 houve um ressurgimento do interesse por redes neurais com o surgimento de melhores algoritmos de treinamento, melhores conhecimentos da estrutura real do cérebro e disponibilidade de computadores mais poderosos, inclusive paralelos [Russell \& Norvig, 2004].

Os sucessos obtidos em aplicações práticas levaram a uma mudança de ênfase quanto ao objetivo da pesquisa na área. Uma parte da pesquisa passa a se dedicar ao estudo de redes neurais vistas apenas como uma representação de modelos matemáticos simulados 
Capítulo 3 Técnicas inteligentes para reconhecimento de padrões

computacionalmente, sem maiores preocupações com o estudo do modelo biológico [Bittencourt, 1996]. Redes neurais são usadas principalmente como uma metodologia inteligente para reconhecimento de padrões em geral (visão computacional, reconhecimento de voz e escrita, etc) com aplicações práticas nas mais diversas áreas como processamento de sinais, previsões baseadas em séries temporais, diagnóstico de falhas, identificação e controle de processos.

Redes neurais não são uma técnica única, constituindo na verdade de famílias de modelos. Muitos destes modelos são organizados a partir de um número de unidades de processamento (chamados neurônios artificiais ou simplesmente neurônios) interligados por um número de conexões ponderadas (sinapses artificiais), seguindo uma determinada arquitetura particular a cada método.

Em geral, uma rede neural é organizada por um vetor de pontos de entrada seguido por uma ou mais camadas de neurônios. Os pontos de entrada apenas fornecem dados, não tendo papel ativo nos cálculos efetuados pela rede. As informações são processadas pelos neurônios e as saídas dos neurônios da última camada são as saídas da rede. As redes podem possuir uma única camada, quando só existe um nó entre qualquer entrada e qualquer saída da rede ou pode ter múltiplas camadas. No caso de ter múltiplas camadas, as camadas anteriores à camada de saída são chamadas de camadas intermediárias, ocultas ou escondidas. Se todos os neurônios comportam-se da mesma forma, a rede é considerada homogênea, caso contrário heterogênea. As redes podem ser de alimentação direta (feedforward), ou acíclica, quando o fluxo de informações é sempre direcionado das entradas para as camadas seguintes até atingir a camada de saída. Neste contexto, 'camada seguinte' não significa a camada necessariamente subsequente, mas qualquer camada adiante da camada considerada. Nas redes recorrentes (feedback), ou cíclicas, não existe direção privilegiada para propagação da informação, havendo retroalimentação em pelo menos uma das conexões. Com relação à quantidade de conexões, a rede pode ser completamente conectada, quando todas as possíveis conexões permitidas pelo modelo estão presentes, caso contrário a rede é fracamente (ou parcialmente) conectada.

O processo de construir uma rede neural envolve uma fase de aprendizado, também chamada de treinamento. Durante a fase de aprendizado, a rede observa uma sequência de dados de entrada e ajusta o peso de suas conexões, seguindo um algoritmo de aprendizado e baseando-se nos dados observados. Algoritmos de aprendizado são divididos geralmente em um de dois tipos: supervisionado, quando os dados de treinamento são previamente classificados por um agente externo à rede, e não supervisionado, quando a rede tenta inferir as relações entre os dados autonomamente. 
Muitos algoritmos de treinamento são inspirados, direta ou indiretamente, na lei de Hebb, proposta em 1949 pelo psicólogo Donald Hebb. Considerando uma rede com uma única camada de $k$ unidades, desejamos encontrar os pesos apropriados $w_{i j}$ para mapear a entrada $x_{i}$ do vetor de entrada n-dimensional $\boldsymbol{x}$ para a saída $y_{j}$ do vetor de saída kdimensional $\boldsymbol{y}$. Usando uma constante $\eta$ chamada de taxa de aprendizado, a lei de Hebb é expressa por [Rojas, 1996]:

$$
\Delta w_{i j}=\eta x_{i} y_{j}
$$

A lei de Hebb pode ser modificada para levar em conta o valor desejado para a saída do neurônio $-d_{j}-$, dando origem à regra Delta [Braga et al., 2000]:

$$
\Delta w_{i j}=\eta x_{i}\left(d_{j}-y_{j}\right)
$$

\subsubsection{Perceptron}

O trabalho de McCulloch e Pitts foi o pioneiro na modelagem de um neurônio artificial para reproduzir o comportamento de um neurônio biológico, mas por utilizar uma função linear, computacionalmente consegue resolver uma quantidade muito limitada de problemas. O percetron, de Rosenblatt, através do uso de uma função diferenciável não linear, consegue maior abrangência na solução de problemas, comparado ao trabalho inicial de McCulloch e Pitts.

O perceptron é o tipo mais simples de rede neural feedforward, isto é, onde as informações fluem através das conexões entre os neurônios da rede de forma unidirecional e acíclica. A rede consiste de uma única camada de $p$ neurônios conectados com um conjunto de $n$ nós de entrada. Os nós de entrada geralmente não são considerados como uma camada da rede porque apenas fornecem valores de entrada, não desempenhando nenhum papel ativo na transformação dos dados para a obtenção dos valores intermediários e de saída. Cada neurônio possui uma conexão com cada um dos nós de entrada e uma saída, assim o número $p$ de saídas é o mesmo que o número de neurônios.

Cada saída $o_{i}$ é calculada como uma função do vetor de entrada $\boldsymbol{x}=\left[x_{1}, \ldots, x_{n}\right]^{T}$, calculada após a propagação dos valores de entrada na rede conforme a equação (3.8):

$$
o_{i}=f\left(a_{i}\right)=f\left(\sum_{k=0}^{n} w_{i k} x_{k}\right) i=1, \ldots, p
$$

onde

$a_{i}$ indica a entrada da rede (instância do vetor $\boldsymbol{x}$ ) para o neurônio $i$ e $w_{i k}$ o peso da conexão entre a i-ésima unidade de saída $o_{i}$ (única saída do neurônio $i$ ) e o k-ésimo valor de 
Capítulo 3 Técnicas inteligentes para reconhecimento de padrões

entrada $x_{k}$, sendo $x_{k} \in[0,1], k=1, \ldots, n$, e $o_{i} \in[0,1], i=1, \ldots, p$. É também considerada a existência de um parâmetro de entrada virtual $x_{0}$ permanentemente atribuído com o valor +1 que sempre adiciona ao somatório do argumento da função de ativação $f$ o valor de limiar (threshold, bias) $w_{i 0}$.

\subsubsection{Regra delta}

O método de correção dos pesos das conexões (treinamento) do perceptron é a regra delta e consiste em uma variação do algoritmo de otimização baseado em gradiente descendente. Sabemos do cálculo diferencial que o gradiente de uma função é um vetor que aponta para a direção e sentido em que a função tem taxa de variação máxima. No perceptron é definida uma função erro entre os valores produzidos pelas saídas dos neurônios e os valores corretos desejados. Como desejamos que este erro seja mínimo, de modo que as saídas calculadas pelos neurônios sejam o mais próximo possível dos valores desejados, usa-se o sentido oposto do vetor gradiente para se obter a maior variação negativa do erro, por isto o nome gradiente descendente.

Suponha que dispomos de um conjunto $T$ de $m$ exemplos de treinamento $q=1, \ldots, m$, associando em cada padrão um vetor de entrada $\boldsymbol{x}^{q}$ a um vetor alvo de saída $\boldsymbol{d}^{q}, T=\left\{\left(\boldsymbol{x}^{q}, \boldsymbol{d}^{q}\right) \mid\right.$ $q=1, \ldots, m\}$. É desejável um procedimento para ajustar os pesos das conexões do perceptron tal que a saída da rede $\mathbf{o}^{q}$ associada ao vetor de entrada $\boldsymbol{x}^{q}$ torne-se cada vez mais similar ao padrão alvo correspondente $\boldsymbol{d}^{q}$ (aprendizado supervisionado).

A partir de um conjunto inicial de valores aleatórios $\mathbf{W}=\left\{w_{i k}\right\}$, a regra de aprendizado deve atualizar o vetor $\mathbf{W}$ para alcançar a solução $\mathbf{W}^{*}$, se existente, em um número finito de passos. $\mathbf{W}^{*}$ representa a matriz de pesos ótima, que produz na média a resposta $\boldsymbol{o}^{q}$ mais próxima de $\boldsymbol{d}^{q}$ para cada padrão de entrada $\boldsymbol{x}^{q}$ com $q=1, \ldots, m$ [Berthold \& Hand, 2003].

A função erro $\mathrm{E}(\mathbf{W})$, diferenciável, mais usada (existem outras), é a soma de erros quadráticos e é definida em função da matriz de pesos $\mathbf{W}$ da rede:

$$
\begin{aligned}
& E(\mathbf{W})=1 / 2 \sum_{q=1}^{m} \sum_{i=1}^{p}\left(o_{i}^{q}-d_{i}^{q}\right)^{2}=\sum_{q=1}^{m} E^{q}(\mathbf{W}) \\
& E^{q}(\mathbf{W})=1 / 2 \sum_{i=1}^{p}\left(o_{i}^{q}-d_{i}^{q}\right)^{2}
\end{aligned}
$$

onde 
$m$ é o número de exemplos do conjunto de treino $T$ e $p$ é o número de unidades de saída da rede.

A partir de um $\mathbf{W}$ inicial (usualmente valores aleatórios dos pesos $\mathrm{w}_{\mathrm{ik}}$ ), o algoritmo do gradiente descentente move os pesos na direção oposta do gradiente:

$$
\begin{aligned}
& w_{i k}(u+1)=w_{i k}(u)+\Delta w_{i k}(u) \\
& \Delta w_{i k}(u)=-\eta \frac{\partial E(u)}{\partial w_{i k}}=-\eta \sum_{q=1}^{m} \frac{\partial E^{q}(u)}{\partial w_{i k}}=\sum_{q=1}^{m} \Delta w_{i k}^{q}(u) \\
& \Delta w_{i k}(u)=-\eta \frac{\partial E^{q}(u)}{\partial w_{i k}}
\end{aligned}
$$

onde

$\eta$ é um número positivo pequeno chamado taxa de aprendizado, e $u$ indica o ciclo corrente do procedimento sobre o conjunto inteiro de treino $T$. Um ciclo $u$ é também referido como uma época.

A abordagem incremental (on-line), ou sequencial, corrige os pesos $w_{i k}$ após cada exemplo de treino $q$ ser apresentado à rede. Neste caso a soma parcial dos erros quadráticos, como na equação (3.10), é adotada e os pesos corrigidos conforme a equação (3.13). O procedimento incremental percorre desta forma todos os exemplos de treino, até que um valor satisfatório de erro seja atingido. A abordagem por ciclo (batch) para correção dos pesos, eq. (3.12), consiste da soma das correções incrementais $\Delta w_{i k}^{q}$ eq. (3.13) sobre todos os exemplos do conjunto de treino $T$ dividida pela quantidade de exemplos $m$.

Lembrando que $o_{i}=f\left(a_{i}\right)$ eq. (3.8), se a função de ativação do neurônio $f(a)$ é diferenciável eq. (3.8), a derivada do erro parcial para o exemplo de treino $q$ torna-se:

$$
\begin{aligned}
& \frac{\partial E^{q}}{\partial w_{i k}}=\frac{\partial 1 / 2 \sum_{i=1}^{p}\left(o_{i}^{q}-d_{i}^{q}\right)^{2}}{\partial w_{i k}}=\left(o_{i}^{q}-d_{i}^{q}\right) \frac{\partial f\left(\sum_{k=0}^{n} w_{i k} x_{k}^{q}\right)}{\partial w_{i k}}= \\
& \left(o_{i}^{q}-d_{i}^{q}\right) f^{\prime}\left(a_{i}^{q}\right) x_{k}^{q}=\delta_{i}^{q} x_{k}^{q}
\end{aligned}
$$

Considerando

$$
\begin{aligned}
\delta_{i}^{q} & =\left(o_{i}^{q}-d_{i}^{q}\right) f^{\prime}\left(a_{i}^{q}\right) \\
a_{i}^{q} & =\sum_{k=0}^{n} w_{i k} x_{k}^{q}
\end{aligned}
$$


Capítulo 3 Técnicas inteligentes para reconhecimento de padrões

então

$$
\Delta w_{i k}^{q}=-\eta \delta_{i}^{q} x_{k}^{q}
$$

\subsubsection{Problema linearmente separável}

Um problema é dito linearmente separável, considerando-se que: em cada dimensão dos dados de entrada do problema estes dados pertencem somente a uma de duas classes distintas, sem interseção, definidas em função do problema. É possível determinar (ao menos) um hiperplano capaz de dividir o espaço da dimensão considerada de tal forma a separar as classes, uma em cada lado do hiperplano.

Na geometria, um hiperplano pode ser um espaço vetorial, transformação afim ou o sub-espaço de dimensão n-1. Em particular, num espaço tridimensional um hiperplano é um plano habitual. Num espaço bi-dimensional, um hiperplano é uma reta. Num espaço unidimensional, um hiperplano é um ponto. Um hiperplano pode ser descrito por uma equação linear não degenerada na seguinte forma:

$$
a_{1} x_{1}+a_{2} x_{2}+\ldots+a_{n} x_{n}=b
$$

Um hiperplano é um espaço vetorial se $b=0$ [Reed \& Marks, 1999].

Sendo um pouco mais formal, definimos que:

Dois conjuntos de pontos A e B em um espaço n-dimensional são ditos linearmente separáveis se existem $n+1$ números reais $w_{1}, \ldots, w_{n+1}$, tal que cada ponto $\left(x_{1}, x_{2}, \ldots, x_{n}\right) \in A$ satisfaz $\sum_{i=1}^{n} w_{i} x_{i} \geq w_{n+1}$ e cada ponto $\left(x_{1}, x_{2}, \ldots, x_{n}\right) \in B$ satisfaz $\sum_{i=1}^{n} w_{i} x_{i}<w_{n+1}$ [Rojas, $1996]$.

Funções usadas para discriminar entre regiões do espaço de entrada são chamadas de curvas de decisão. Algumas destas curvas estudadas são polinomiais e splines [Rojas, 1996].

Se o problema não for linearmente separável, mesmo se a funçao de ativação do neurônio f(a) for uma função contínua não linear, ainda assim é impossível separar as duas classes com somente uma curva de decisão do tipo $x_{2}=f\left(x_{1}\right)$. As funções mais empregadas para f(a) em redes neurais são a sigmoid e a tangente hiperbólica. Se o problema não é linearmente separável em um espaço de saída p-dimensional, ao menos um dos p neurônios do Perceptron irá falhar na definição da linha discriminativa do espaço de entrada. Perceptrons não podem resolver problemas não linearmente separáveis. $\mathrm{O}$ exemplo clássico 
de problema não linearmente separável em redes neurais é a função binária ou-exclusivo (XOR).

\subsubsection{MLP}

Uma rede neural com arquitetura MLP (multilayer feedforward neural network, Multi-Layer Perceptron) é uma evolução da rede Perceptron tendo duas ou mais camadas de unidades de processamento.

Quando o problema não é linearmente separável, a forma mais fácil de transformar o vetor de entrada consiste na introdução de uma ou mais camadas de neurônios artificiais na arquitetura Perceptron transformando-a em uma arquitetura MLP. Deste modo a primeira camada de neurônios preprocessa o espaço de entrada e a segunda camada constrói as superfícies de discriminação necessárias para resolver o problema [Berthold \& Hand, 2003]. Em uma rede MLP, o processamento realizado por cada neurônio é definido pela combinação dos processamentos realizados pelos neurônios da camada anterior conectados a ele. Conforme se avança nas camadas, as funções implementadas tornam-se mais e mais complexas:

- primeira camada intermediária: cada neurônio traça retas no espaço de padrões de treinamento;

- segunda camada intermediária: cada neurônio combina as retas traçadas pelos neurônios da primeira camada conectados a ele, formando regiões convexas, onde o número de lados é definido pelo número de retas combinadas;

- camada de saída: cada neurônio forma regiões que são combinações (união) das regiões convexas definidas pelos neurônios da segunda camada conectados a ele [Braga et al., 2000].

A utilização de um grande número de camadas intermediárias não é recomendada porque cada vez que o erro é medido durante o treinamento, é propagado para a camada anterior e se torna menos preciso. A única camada que tem uma noção precisa do erro cometido pela rede é a camada de saída. A última camada intermediária recebe apenas uma estimativa sobre o erro. A penúltima camada intermediária, uma estimativa da estimativa, e assim por diante [Braga et al., 2000].

O algoritmo mais conhecido para treinamento de MLP é a retropropagação (backpropagation) reinventado independentemente por vários autores com propósitos diferentes. Este algoritmo pode ser considerado como uma generalização da regra delta para 
Capítulo 3 Técnicas inteligentes para reconhecimento de padrões

redes MLP. O backpropagation é um algoritmo de treinamento supervisionado e ocorre através de iterações em duas fases - forward e backward. A fase forward é utilizada para definir a saída da rede para um dado padrão de entrada. $\mathrm{O}$ algoritmo pode ser resumido da seguinte forma:

i. apresenta-se um exemplo à rede e obtém-se a saída correspondente (fase forward);

ii. calcula-se o vetor de erro que consiste na diferença entre a saída obtida e a esperada (início da fase backward);

iii. calcula-se o gradiente do vetor de erro e atualiza-se, utilizando a regra delta, os pesos da camada de saída;

iv. propaga-se para trás (em direção da camada dos terminais de entrada de dados), camada por camada, os valores de gradiente atualizando-se os pesos dos neurônios (fim da fase backward).

O algoritmo backpropagation tem sido usado com resultados satisfatórios em uma larga gama de problemas de classificação, predição e aproximação de funções e representa o mais famoso procedimento de treinamento para redes neurais.

\subsubsection{Fórmulas e derivação}

Suponha uma arquitetura de rede Perceptron multicamadas, completamente conectada, com $L$ camadas $l=0,1, \ldots, L, \operatorname{com} l=0$ denotando os terminais de entrada e $l=L$ a camada de saída. Cada camada $l$ tem $n(l)$ neurônios. O valor de saída $o_{i}$ de cada unidade $i$ na camada $l$ ainda pode ser calculado através da eq. 3.1, fazendo as entradas $x_{k}$ da unidade $i$ corresponderem às saídas $o_{k}$ da camada $l-1$ :

$$
o_{i}=f_{i}\left(a_{i}\right)=f_{i}\left(\sum_{k=0}^{n(l-l)} w_{i k} o_{k}\right) i=1, \ldots, n(l)
$$

onde

$a_{i}$ representa a entrada de rede para a unidade $i, f_{i}()$ é a função de ativação e $n(l-1)$ o número de unidades na camada $l-1$. Após a apresentação de um padrão, a eq. (3.18) é usada para os cálculos da fase forward do backpropagation [Berthold \& Hand, 2003].

A função soma dos erros quadráticos $E^{q}(\boldsymbol{W})$ eq. (3.10) é assumida e a abordagem incremental eq. (3.17) é aplicada em um conjunto de treino $T$ de m exemplos,

$$
T=\left\{\left.\left(\boldsymbol{x}^{q}, \boldsymbol{d}^{q}\right)\right|_{q=1, \ldots, m}\right\} .
$$


O primeiro passo do algoritmo consiste da aplicação do padrão de entrada $\boldsymbol{x}^{q}$ e do cálculo dos valores de saída $o_{1}^{q}, \ldots, o_{p}^{q}$ através das camadas da rede. A avaliação da função erro $E^{q}(\boldsymbol{W})$ eq. (3.10) na camada de saída L conclui a fase de propagação forward.

Se o erro de saída $E^{q}(\boldsymbol{W})$ é diferente de zero, uma correção $\Delta \boldsymbol{W}^{q}$ da matriz de pesos é necessária. Como na regra delta, seguindo a estratégia do gradiente descendente, a atualização de peso definida na eq. (3.19) é aplicada a cada peso da rede $w_{i k}$ conectando a unidade $k$ na camada $l-1$ à unidade $i$ na camada $l$ [Berthold \& Hand, 2003].

$$
\Delta w_{i k}^{q}=-\eta \frac{\partial E^{q}}{\partial w_{i k}}
$$

Usando a regra da cadeia, a derivada parcial pode ser expressa como:

$$
\frac{\partial E^{q}}{\partial w_{i k}}=\frac{\partial E^{q}}{\partial a_{i}^{q}} \quad \frac{\partial a_{i}^{q}}{\partial w_{i k}}
$$

Da eq. (3.18) obtemos:

$$
\frac{\partial a_{i}^{q}}{\partial w_{i k}}=o_{k}^{q}
$$

e usando

$$
\delta_{i}^{q}=\frac{\partial E^{q}}{\partial a_{i}^{q}}
$$

derivamos:

$$
\begin{array}{llll}
\frac{\partial E^{q}}{\partial w_{i k}} & =\delta_{i}^{q} & o_{k}^{q} & \\
\Delta w_{i k}^{q}=-\eta & \delta_{i}^{q} & o_{k}^{q} & i \in \text { camada } l \\
& & k \in \text { camada } l-1
\end{array}
$$

que tem a mesma forma da regra delta na eq. (3.17) para a atualização de peso da arquitetura Perceptron de uma camada.

Para as unidades de saída (unidade $i \epsilon$ camada $L$ ), a regra delta eq (3.17) é aplicada:

$$
\delta_{i}^{q}=\frac{\partial E^{q}}{\partial a_{i}^{q}}=f^{\prime}\left(a_{i}^{q}\right)\left(o_{i}^{q}-d_{i}^{q}\right) \quad i \in \text { camada de saída } L
$$


Capítulo 3 Técnicas inteligentes para reconhecimento de padrões

Precisamos também avaliar $\frac{\partial E^{q}}{\partial a_{i}^{q}}$ para unidades escondidas, isto é, para a unidade $i$ $\in$ camada $l$ com $l<L$. Usando novamente a regra da cadeia para derivadas parciais, introduzimos a contribuição da camada $l+1$ para o cálculo de $\delta_{i}^{q}$ :

$$
\delta_{i}^{q}=\frac{\partial E^{q}}{\partial a_{i}^{q}}=\sum_{j=1}^{n(l+1)} \frac{\partial E^{q}}{\partial a_{j}^{q}} \frac{\partial a_{j}^{q}}{\partial a_{i}^{q}}
$$

onde

$\mathrm{n}(1+1)$ é o número de unidades j na camada $1+1 . \mathrm{O}$ termo $\frac{\partial E^{q}}{\partial a_{i}^{q}}$ é exatamente a quantidade $\delta_{j}^{q}$ definida para unidades $\mathrm{j}$ na camada $1+1$, e considerando eq. (3.18), temos que

$$
\begin{aligned}
& \frac{\partial a_{j}^{q}}{\partial a_{i}^{q}}=f^{\prime}\left(a_{i}^{q}\right) w_{i j} \text {. Assim, para as unidades escondidas i: } \\
& \delta_{i}^{q}=f^{\prime}\left(a_{i}^{q}\right) \sum_{j=1}^{n(l+1)} w_{j i} \delta_{j}^{q} \quad i \in \text { camada } l<L \\
& j \in \text { camada } l+1
\end{aligned}
$$

Começando com o cálculo dos valores $\delta$ na camada de saída $L$ eq. (3.25), é possível calcular os valores $\delta$ das unidades escondidas nas camadas intermediárias $l<\mathrm{L}$ usando os valores $\delta$ da camada $l+1$ eq. (3.27).

Quando todos os pesos são atualizados com $\Delta w_{i k}^{q}$ na eq. (3.24) (fase backward do algoritmo), o próximo padrão de treinamento $\mathbf{x}^{\mathrm{q}}$ é apresentado à rede e o procedimento recomeça. O critério de parada pode ser o uso de um limite de erro aceitável para o problema no cálculo da função erro, uma avaliação da capacidade de generalização da rede para padrões de entrada não usados no treinamento (padrões de validação ou teste) ou um máximo para o número de épocas executadas [Berthold \& Hand, 2003].

\subsubsection{Heurísticas para melhorar a convergência}

Conforme já dito, a abordagem online (sequencial) atualiza os pesos da rede após a apresentação de cada padrão. É geralmente mais rápida, principalmente se o conjunto de entrada for grande e redundante. Outra vantagem é que requer menos memória. A abordagem batch (por ciclo) atualiza os pesos após todos os padrões do conjunto de treinamento terem sido apresentados à rede. É geralmente mais estável, mas pode ser lenta se o conjunto de treinamento for grande e redundante; apresenta uma estimativa mais 
precisa do vetor gradiente, à custa de mais memória, pois é necessário armazenar-se os gradientes parciais em cada conexão para cada um dos padrões de entrada para depois calcular o gradiente médio [Braga et al., 2000].

É esperado do algoritmo de aprendizado backpropagation convergir para a configuração de pesos ótima $\mathbf{W}^{*}$, que representa a localização do mínimo absoluto na superfície de erro $E(\boldsymbol{W})$. Entretanto, como qualquer procedimento do gradiente descendente, backpropagation converge para qualquer configuração da matriz de peso W com gradiente de erro zero. Se a rede tem um grande número de parâmetros livres, muitos outros pontos de mínimo ou estacionários (em uma parte plana da superfície), chamados de mínimo local, podem existir na superfície de erro, apresentando a matriz de peso $\mathrm{W}$ com gradiente zero. No ponto de mínimo local o valor da função erro pode não ser satisfatoriamente baixo e consequentemente o desempenho da rede pode não ser suficientemente próximo do comportamento desejado [Berthold \& Hand, 2003].

A configuração inicial determina para qual mínimo, local ou global, o algoritmo irá convergir. Usualmente pequenos valores aleatórios são escolhidos inicialmente para a matriz de pesos. Eles devem ser pequenos para evitar o risco de cair na área de saturação 0 ou 1 da função de ativação sigmoidal logo no ínicio do procedimento e se ficar preso em um mínimo local próximo ao ponto inicial, possivelmente com um valor muito alto da função de erro. Se o procedimento termina em um mínimo local posicionado em um vale ou planície, pequenas perturbações (ruído) nos valores dos pesos podem ajudar a sair do mínimo local e ajudar na procura por um mínimo melhor na função de erro. Na abordagem online, uma forma de estimular este comportamento é apresentar os padrões de treinamento à rede em uma ordem aleatória [Berthold \& Hand, 2003].

Recomenda-se que a taxa de aprendizado $\eta$ esteja compreendida no intervalo $(0,1)$ e que seu valor seja decrescente ao longo do procedimento. Uma taxa inicial maior no início permite que algorimo comece a busca dando passos mais largos na superfície à procura do mínimo, mas à medida que o algoritmo se aproxima do mínimo, o tamanho dos passos precisa ser reduzido, caso contrário pode cair-se em um ponto fora do mínimo e haver oscilação na convergência. Quando a região do mínimo é larga e aplainada produz pequenos valores para o gradiente, e um valor grande de $\eta$ resulta em uma convergência mais rápida. Entretanto, na presença de um mínimo profundo e estreito, um valor pequeno de $\eta$ evita que a solução seja ultrapassada por uma atualização muito grande na matriz de pesos [Berthold \& Hand, 2003].

Para evitar-se oscilações bruscas no entorno dos pontos de mínimo, uma alternativa é usar a fórmula da eq. (3.28) (conhecida como regra delta generalizada) no lugar da eq. 
Capítulo 3 Técnicas inteligentes para reconhecimento de padrões

(3.12) (regra delta). É fácil observar que a eq. (3.28) abrange a eq. (3.12).

$$
\Delta w_{i k}(u)=-\eta \frac{\partial E(u)}{\partial w_{i k}}+\alpha \Delta w_{i k}(u-1)
$$

onde

$\alpha$ é uma constante positiva arbitrária, denominada termo momento, usualmente escolhida no intervalo $0 \leqslant \alpha<1$ [Haykin, 1998]. Quando $\alpha$ é zero, o algoritmo opera da forma tradicional, sem o uso de momento.

A idéia é dar a cada conexão $w_{i k}$ alguma inércia ou momento tal que cada mudança $\Delta w_{i k}(u)$ não mova o peso $w_{i k}$ muito além da direção geral da atualização [Berthold \& Hand, 2003]. A inclusão do termo momento pode aumentar a velocidade de aprendizado (aceleração) em regiões muito planas da superfície de erro e reduzir o perigo de instabilidade, suprimindo a oscilação de pesos em vales e ravinas [Braga et al., 2000]. Isto ocorre da seguinte forma: quando a derivada parcial $\frac{\partial E(u)}{\partial w_{i k}(u)}$ tem o mesmo sinal algébrico em iterações consecutivas, o valor de $\Delta w_{i k}(u)$ cresce em magnitude e portanto o peso $w_{i k}$ é ajustado por uma quantidade maior; quando a derivada parcial $\frac{\partial E(u)}{\partial w_{i k}(u)}$ tem sinais opostos em iterações consecutivas, o valor de $\Delta w_{i k}(u)$ diminui em magnitude, o peso $w_{i k}$ é ajustado por uma quantidade pequena, desta forma a inclusão do momento tem um efeito estabilizante em direções que oscilam de sinal.

Os valores da taxa de aprendizado e do termo momento precisam ser compatibilizados para garantir estabilidade e convergência ao algoritmo backpropagation. Ao longo das iterações o valor de $\eta$ precisa diminuir ao passo que o valor de $\alpha$ deve aumentar [Haykin, 1998].

\subsubsection{Generalização e validação}

O principal propósito de uma rede neural é construir um modelo geral das relações de entrada/saída baseado nos exemplos de treinamento. Um modelo geral significa que o conjunto das relações de entrada/saída derivadas do conjunto de treino, aplicam-se igualmente bem para novos conjuntos de dados do mesmo problema não inclusos no conjunto de treino [Berthold \& Hand, 2003]. Assim, uma rede é considerada capaz de generalizar bem quando o mapeamento entrada/saída calculado pela rede é correto (ou próximo) para dados de teste não usados no treinamento da rede. Generalização é influenciada pelos fatores [Haykin, 1998]: 
i. tamanho do conjunto de treino, e quão representativo é do domínio de interesse;

ii. arquitetura da rede

iii. complexidade física do problema.

Os exemplos inclusos no conjunto de treino precisam descrever completa e acuradamente as regras que se espera que a rede aprenda. Isto significa uma quantidade suficiente de dados claros e corretamente nomeados, proporcionalmente distribuídos entre as classes de saída. Na prática, os dados disponíveis para treinamento usualmente são parcialmente incorretamente nomeados (em classes), com ruído e não descrevem exaustivamente todas as particularidades das relações entre os padrões de entrada [Berthold \& Hand, 2003].

Um número muito grande de parâmetros livres (a arquitetura da rede é muito grande) pode memorizar todos os exemplos do conjunto de treino com o ruído associado, erros, inconsistências e desta forma desempenhar uma generalização pobre quando novos dados são apresentados. Este fenômeno é conhecido como overfitting (overtraining). Acredita-se que o overfitting acontece quando o modelo tem mais parâmetros livres (o número de pesos da rede, aproximadamente falando) do que restrições (o número de exemplos de treino independentes, aproximadamente). Na situação contrária, um número muito pequeno de parâmetros do modelo pode impedir a função erro de atingir valores satisfatórios e o modelo de aprender [Berthold \& Hand, 2003].

Uma maneira de se tentar evitar o overfitting é o uso de um conjunto de dados não visto durante o treinamento da rede para aferir a qualidade da generalização do modelo. $\mathrm{Na}$ validação simples (cross-validation, hold out), o conjunto de padrões de entrada nomeados (em classes) $D$ é aleatoriamente dividido em duas partes: uma é usada como o conjunto de treino tradicional para ajustar os parâmetros do modelo para o classificador (existem vários métodos estatísticos de classificadores, além das redes neurais). A outra parte - o conjunto de validação - é usada para estimar o erro de generalização. Como o objetivo é um baixo erro de generalização, o classificador é treinado até se obter o erro mínimo do conjunto de validação. Para isto, é essencial que o conjunto de validação (ou teste) não inclua pontos usados para o treino dos parâmetros no classificador, um erro metodológico conhecido como "teste no conjunto de treino" [Duda et al., 2001].

Para se evitar o "teste no conjunto de treino", pode-se fazer a seguinte variação: dividi-se o corpo de padrões $D$ em dois conjuntos: treino e teste, e então se divide o conjunto de treino em dois subconjuntos: estimação e validação. Faz-se o treino do classificador usando os conjuntos de estimação para treino e validação para medir a generalização, como mencionado no parágrafo anterior. Para se previnir da possibilidade 
Capítulo 3 Técnicas inteligentes para reconhecimento de padrões

dos dados de estimação conterem os dados de validação, o desempenho da generalização do modelo selecionado é posteriormente medido no conjunto de teste, que é diferente do conjunto de validação [Haykin, 1998].

Existem variantes do método cross-validation, úteis na prática quando não há uma grande quantidade de padrões nomeados. Estas variações consistem em treinar e validar o classificador com diversas combinações de subconjuntos do conjunto original de padrões $D$ e apresentam alto custo computacional em função da necessidade de treinar o classificador diversas vezes.

Multifold-cross-validation (m-fold cross-validation) consiste em dividir o conjunto disponível de $n$ exemplos em $\mathrm{m}$ subconjuntos, $m>1$; isto supõe que $n$ é divisível por $m$. $\mathrm{O}$ modelo é treinado usando todos os subconjuntos exceto um, e o erro de validação é medido testando-se o subconjunto excluído. O procedimento é repetido $m$ vezes, cada vez usando um subconjunto diferente para validação. O desempenho do modelo é medido pela média do erro quadrático da validação das $m$ execuções do procedimento [Haykin, 1998].

Quando o número de padrões $n$ é muito reduzido, podemos usar a forma extrema do multifold-cross-validation, quando $m=n$, conhecida como método leave-one-out (jackknife). Neste caso, $n-1$ exemplos são usados para treinar o modelo e este é validado pelo exemplo excluído. O procedimento é repetido $n$ vezes, cada vez reservando um exemplo diferente para validação. A média do erro quadrático das validações é feita sobre os $n$ experimentos [Haykin, 1998].

Na abordagem bootstrap, um conjunto de dados é criado pela seleção aleatória de $n$ pontos do conjunto de padrões de entrada $D$, com substituição. (Como o próprio $D$ contém $n$ pontos, há quase sempre duplicação de pontos individuais em um conjunto de dados bootstrap.) Na estimação do bootstrap, o processo de seleção é repetido independentemente $b$ vezes, produzindo $b$ conjuntos de dados bootstrap, que são tratados como conjuntos independentes [Duda et al., 2001]. O autor não faz referência aos dados de validação.

Apresentados os métodos de validação, gerais para qualquer classificador, é necessário mostrar como empregá-los no algoritmo backpropagation para obter-se um bom modelo de generalização da rede neural. Durante o procedimento de treinamento, o erro inicialmente decresce tanto para o conjunto de treino (ou estimação, caso o conjunto de treino tenha sido particionado em estimação e validação) quanto para o conjunto de validação, à medida que a rede generaliza os dados de treino para construir a função entrada/saída correspondente. Após alguns ciclos de treino $u^{*}$, geralmente nos últimos estágios do treinamento, a rede começa a memorizar (overfitting) características com ruído do conjunto de treino. Consequentemente o erro no conjunto de validação aumenta, 
enquanto o erro no conjunto de treino continua diminuindo. O procedimento de aprendizado pode então ser encerrado neste passo $u^{*}$ com o menor erro para o conjunto de validação, porque neste ponto é esperado que a rede apresente o melhor desempenho de generalização. Esta técnica é conhecida como early stopping [Berthold \& Hand, 2003].

Outra abordagem, conhecida como treino com ruído, adiciona ruído em cada padrão de treino, para suavizar os dados de treinamento de forma a não ocorrer a memorização. Um novo vetor aleatório é adicionado a cada padrão de entrada antes dele alimentar a rede. Assim torna-se difícil para a rede memorizar pontos individuais precisamente, uma vez que os padrões nunca são repetidos com os mesmos dados ao longo das épocas [Berthold \& Hand, 2003].

A quantidade de parâmetros livres é outro fator que influência o overfitting. Se forem muito numerosos em relação aos dados de entrada, a rede consegue memorizar todos os padrões. O problema é que não se conhece antecipadamente qual a melhor arquitetura da rede neural para um determinado conjunto de dados. Assim foram desenvolvidos métodos que dinamicamente alteram a estrutura da rede durante o treinamento. Há duas abordagens: métodos de crescimento (growing), que a partir de uma arquitetura inicial pequena adicionam parâmetros à rede; e métodos de poda (prunning), que a partir de uma arquitetura inicial superestimada reduzem o tamanho da rede.

\subsubsection{SOM}

Redes auto-organizáveis oferecem um paradigma para aplicações em que a informação fornecida limita-se ao conjunto de padrões de entrada. Estes modelos de rede têm treinamento não supervisionado, isto é, a rede neural tenta agrupar/classificar os dados sozinha, sem o auxílio externo de um supervisor que informe a rede se a classificação feita por ela está certa ou errada, nem qual a classe correta para um dado padrão de entrada.

O modelo SOM (self-organizing map), também conhecido como redes ou mapas de Kohonen (devido ao nome de seu criador), gera um mapa topológico com os dados de entrada agrupados por similaridade através de treinamento não supervisionado. Inicialmente é criada uma grade de neurônios, em geral bidimensional, com um padrão de conexão entre um neurônio e seus vizinhos, de forma que se pode determinar para um dado neurônio uma vizinhança composta pelos neurônios em seu redor na grade (por exemplo, quadrada, hexagonal, gaussiana (circular) fig. 3.3.1). 

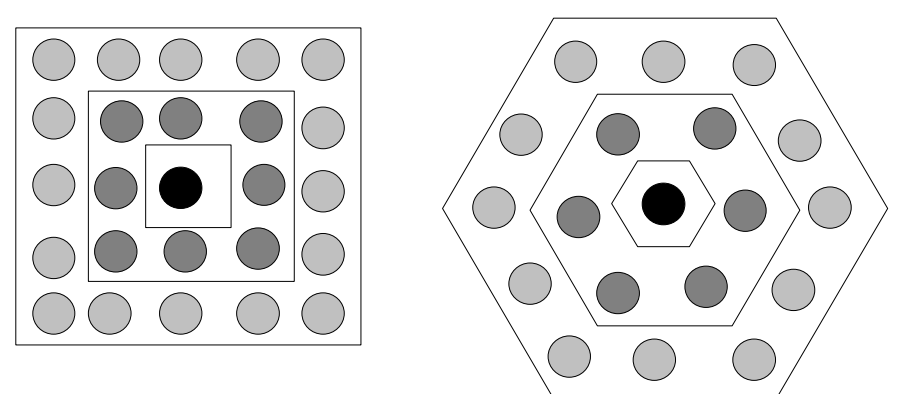

Figura 3.1.1 Dois exemplos de vizinhanças topológicas em duas dimensões, quadrada e hexagonal, para o mapa de Kohonen. O neurônio vencedor, representado no centro, obtém a maior atualização dos pesos enquanto as unidades mais distantes recebem atualizações menores.

Os padrões de entrada então são apresentados repetidamente à rede e para cada padrão é escolhido o neurônio da grade cujos pesos apresentem a maior similaridade (neurônio vencedor) com os valores do padrão de entrada. A similaridade é calculada usando-se a distância euclidiana entre os valores de entrada e o vetor de pesos do neurônio [Braga et al., 2000]. O neurônio que possuir a menor distância do padrão de entrada é escolhido como vencedor.

Seja $m$ a dimensão do espaço dos dados de entrada e $\mathbf{x}$ um padrão de entrada denotado por

$$
\mathbf{x}=\left[\mathrm{x}_{1}, \mathrm{X}_{2}, \ldots, \mathrm{X}_{\mathrm{m}}\right]^{\mathrm{T}}
$$

O vetor de pesos de cada neurônio da grade (rede) tem a mesma dimensão do espaço de entrada. Seja $\mathbf{w}_{\mathbf{j}}$ o vetor de pesos do neurônio $\mathbf{j}$ denotado por

$$
\begin{aligned}
& \mathbf{w}_{\mathbf{j}}=\left[\mathrm{w}_{\mathrm{j} 1}, \mathrm{w}_{\mathrm{j} 2}, \ldots, \mathrm{w}_{\mathrm{jm}}\right]^{\mathrm{T}} \\
& \text { Seja } \mathrm{i}(\mathbf{x})=\min _{\mathrm{j}}\left\|\mathbf{x}-\mathbf{w}_{\mathbf{j}}\right\|=\min _{\mathrm{j}} \sum_{k=1}^{m}\left|x_{k}-w_{j k}\right|
\end{aligned}
$$

Este neurônio i(x) que apresenta o melhor casamento com o padrão apresentado é chamado de neurônio vencedor [Haykin, 1998].

Os pesos do neurônio vencedor e de seus vizinhos são atualizados com variações de intensidade (quanto mais distante o neurônio vizinho estiver do neurônio vencedor menor é a variação da atualização) de forma a deixar os pesos destes neurônios mais parecidos com 
os valores do padrão de entrada apresentado (fig. 3.3.1). O processo é repetido até haver uma convergência do algoritmo e as atualizações dos pesos dos neurônios apresentarem variações insignificantes. A fórmula para a atualização dos pesos é

$$
\boldsymbol{w}_{j}(n+1)=\boldsymbol{w}_{j}(n)+\eta(n) \cdot h_{j, i}(x)(n) \cdot\left(\boldsymbol{x}-\boldsymbol{w}_{j}(n)\right)
$$

onde:

$\boldsymbol{w}_{j}$ é o vetor de pesos do neurônio $j$ a ser atualizado;

$\eta \quad$ é a taxa de aprendizado, que deve ser reduzida progressivamente ao longo do processamento;

$h_{j, i}(x)$ é um valor atribuído em função da vizinhança, isto é, da distância do neurônio $j$ ao neurônio vencedor $i(\boldsymbol{x})$;

$\boldsymbol{x}$ são os valores do padrão de entrada.

Resultados melhores são obtidos durante o treinamento com mapa de Kohonen usando uma vizinhança larga em torno do neurônio vencedor no início e então sendo encolhida ao longo do tempo, fato demonstrado por numerosas simulações [Kohonen, 1989].

\subsection{Algoritmos genéticos}

Um algoritmo genético (ou AG) é uma variação do algoritmo de busca em feixe estocástica, em que a combinação de 2 estados pais são usados para a geração dos estados sucessores, em vez de serem gerados pela modificação de um único estado como é feito na busca em feixe estocática convencional . A analogia em relação à seleção natural tém o intuito de simular a reprodução sexuada, em dados genéticos de um filho são oriundos de dois progenitores diferentes [Russell \& Norvig, 2004].

AGs usam uma codificação de parâmetros baseada em strings, usualmente binária, representando o esquema de codificação discreto dos nucleotídeos nos cromossomos celulares. Assim, genótipos em AGs podem ser definidos como vetores de bits (strings de bits), nos quais pontos de mutação são definidos pela troca de bits com uma certa probabilidade. Um operador recombinante de crossover modela a quebra de 2 cromossomos e a restituição cruzada subsequente, que é observada durante a reprodução sexuada natural. Um valor de avaliação é atribuído a cada indivíduo (cromossomo) dependendo da tarefa de otimização a ser resolvida. Seleção dentro de uma população é executada em função de adequação: quanto melhor um indivíduo for avaliado, maior a probabilidade de ser escolhido para a geração seguinte [Berthold \& Hand, 2003]. 
Capítulo 3 Técnicas inteligentes para reconhecimento de padrões

Em AGs, um cromossomo em sua forma mais simples pode ser descrito como um string haplóide [Berthold \& Hand, 2003], que é uma cadeia simples de genes através de um alfabeto de $\mathrm{k}$ elementos $\mathrm{A}=\left\{\mathrm{a}_{1}, \ldots, \mathrm{a}_{\mathrm{k}}\right\}$. Assim, definimos um cromossomo simples de comprimento n como um vetor $\mathbf{g}$ da forma:

$$
\mathbf{g}=\left(\mathrm{g}_{1}, \ldots, \mathrm{g}_{\mathrm{n}}\right) \operatorname{com} \mathrm{g}_{\mathrm{i}} \in \mathrm{A} \text { para } 1 \leq \mathrm{i} \leq \mathrm{n} .
$$

Dada uma população de pais (geração atual), a produção dos filhos da próxima geração é conseguida através de 3 operadores genéticos principais, como mostrado na fig. 3.4.1 [Duda et al., 2001]:

- replicação - um cromossomo é reproduzido sem modificações;

- crossover - um ponto comum de divisão é escolhido ao longo do comprimento de dois cromossomos pais A e B. A primeira parte do cromossomo A é concatenada com a segunda parte do cromossomo B produzindo um filho; a primeira parte do cromossomo B é concatenada com a segunda parte do cromossomo A produzindo outro filho;

- mutação - um ou mais genes em um cromossomo tem uma pequena chance de ter seu valor alterado.

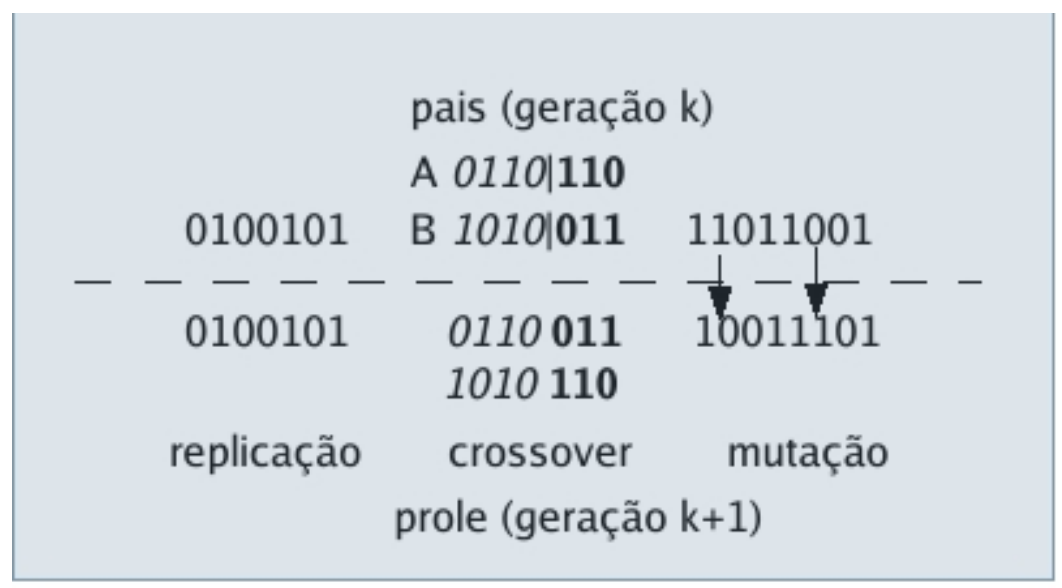

Figura 3.2.1 Operadores genéticos.

Estes são os principais operadores em sua forma mais simples, mas existe uma grande variedade destes operadores, principalmente do crossover (com mais de um ponto de divisão, por exemplo), além de outros operadores como inversão e inserção [Berthold \& Hand, 2003].

Para o uso de um algoritmo genético deve-se primeiro escolher uma forma de 
representação em vetor (cromossomo, indivíduo) dos atributos relevantes a um possível conjunto solução do problema e a determinação de uma função de avaliação tal que dado um indivíduo é possível atribuir-lhe uma nota, refletindo sua capacidade de solução do problema. Cria-se uma população inicial de indivíduos e aplicando operadores genéticos cria-se uma geração de indivíduos filhos. Durante o processo evolutivo, a população é avaliada. Os mais aptos são mantidos, isto é, os que representam soluções melhores para o problema e foram melhor avaliados, enquanto os outros são descartados (darwinismo). Os membros mantidos pela seleção podem sofrer modificações em suas características fundamentais através de mecanismos como mutações e crossovers, gerando descendentes para a próxima geração. Este processo, chamado de reprodução, é repetido até que uma solução satisfatória seja encontrada [Braga et al., 2000].

AGs podem ser usados quando não há informação disponível sobre o gradiente da função nos pontos avaliados. A própria função de avaliação não precisa ser contínua ou diferenciável, e mesmo que apresente vários mínimos ou máximos locais, AGs podem conseguir bons resultados [Rojas, 1996]. Apesar de ser uma técnica computacionalmente cara, AGs podem ser facilmente paralelizados quando há disponibilidade de CPUs.

A principal vantagem dos AGs vem da operação do crossover, que tem a habilidade de combinar grandes blocos de genes que evoluem de forma independente para executar funções úteis, elevando o nível de granularidade no espaço em que a busca opera [Russell \& Norvig, 2004].

\subsection{Bioinformática}

Bioinformática é o casamento de biologia e tecnologia da informação. A disciplina abrange quaisquer ferramentas e métodos computacionais para gerenciar, analisar e manipular grandes conjuntos de dados biológicos [Westhead et al., 2002]. Essencialmente, bioinformática tem três componentes:

- a criação de bases de dados permitindo o armazenamento e gerenciamento de grandes conjuntos de dados biológicos;

- o desenvolvimento de algoritmos e estatísticas para determinar relacionamentos entre membros de grandes conjuntos de dados;

- o uso destas ferramentas para a análise e interpretação de vários tipos de dados biológicos, incluindo sequências de DNA, RNA e proteínas, estruturas protéicas, perfis de expressão de gene e vias bioquímicas.

O termo bioinformática surgiu nos anos 1990 e era originariamente sinônimo de 
gerenciamento e análise de dados de sequência de DNA, RNA e proteína. Ferramentas computacionais para análise de sequências têm sido disponíveis desde os anos 1960s mas havia um interesse pequeno até que avanços na tecnologia de sequenciamento conduziram a uma rápida expansão no número de sequências armazenadas em bases de dados como a base GenBank. Agora o termo foi expandido para incorporar muitos outros tipos de dados biológicos como estruturas de proteínas, perfis de expressão de gene e interações entre proteínas. Cada uma destas áreas requer seu próprio conjunto de bases de dados, algoritmos e métodos estatísticos [Westhead et al., 2002].

$\mathrm{Na}$ área de genética, biologia molecular e bioinformática, redes neurais de diversos modelos têm sido aplicadas com grande frequência em diversos problemas. Fayos et al. usaram mapas de Kohonen para a previsão de algumas propriedades estruturais de cristais, em particular, os tipos de estrutura secundária construídas por ligações hidrogênio e contendo o anel pirazole [Fayos et al., 2005]. Hasegawa et al. desenvolveram um método 3D-QSAR (3 dimensional quantitative structure-activity relationship) baseado em superfície usando mapas de Kohonen e three-way partial least squares para representação do potencial eletrostático em superfícies [Hasegawa et al., 2002]. Gutteridge et al. treinaram uma rede neural MLP para identificar resíduos catalíticos encontrados em enzimas, baseado na análise da estrutura e da sequência [Gutteridge et al., 2003]. Fariselli, Casadio e seus colaboradores utilizaram redes neurais MLP para a previsão de contatos entre resíduos de proteínas [Fariselli at al., 2001a] [Pollastri at al., 2001] [Fariselli at al., 2002] [Fariselli \& Casadio, 1999] [Fariselli at al., 2001b]. Dietmann e Frommel treinaram uma rede MLP com um conjunto de entrada formado por hélices para a previsão de dados MSPs (molecular surface patch) [Dietman \& Frommel, 2002]. Berry et al. treinaram redes neurais para prever sítios de fosforilação em proteínas [Berry et al., 2004]. 


\section{Capítulo 4 Modelagem do problema}

O problema tratado nesta dissertação é a pesquisa do uso de métodos inteligentes de tecnologia da informação para a previsão da posição dos átomos de hidrogênio, nas cadeias laterais dos aminoácidos em proteínas.

A idéia principal é que o átomo de hidrogênio, ligado covalentemente ao átomo doador da ligação hidrogênio, tem sua posição definida principalmente em função da presença de um (ou mais) átomo(s) receptor(es) da ponte. Assim, uma rede neural poderia ser treinada para reconhecer os padrões de ligações hidrogênio e calcular a posição do hidrogênio na ponte.

Para se poder fazer o treinamento da rede neural, o problema foi particionado em 3 etapas principais: extração dos dados sobre padrões de ligações hidrogênio da base de dados PDB; agrupamento de padrões similares (rede neural SOM, algoritmo proposto de fusão de grupos), superposição dos padrões de um grupo (algoritmo genético) e treinamento da rede para previsão do hidrogênio (rede neural MLP). Programas em $\mathrm{C}++$ foram implementados para atender a cada necessidade das várias etapas da modelagem. O problema inicial foi restringido apenas para os hidrogênios de aminoácidos que possuem o grupo $\mathrm{OH}$ (hidroxila) na cadeia lateral, não cobrindo assim os casos de aminoácidos que possuem 2 ou 3 hidrogênios nas cadeias laterais, ou o grupo SH.

\subsection{Extração dos dados}

\subsubsection{Vizinhança}

Consideremos um padrão de ligação hidrogênio como sendo o conjunto de átomos antecessor do doador (A), doador do hidrogênio (D), hidrogênio $(\mathrm{H})$ e possíveis receptores do átomo de hidrogênio $\left(\mathrm{R}_{\mathrm{i}}\right)$ contidos em uma dada vizinhança para a formação de uma ligação hidrogênio. Vamos denominar de vizinhança cada um destes conjuntos de átomos que representa um dado padrão de uma ligação hidrogênio. Os átomos antecessor, doador e hidrogênio são escolhidos em função do aminoácido a que pertencem (tab. 4.1.1) e os átomos receptores são quaisquer outros átomos próximos do tipo oxigênio $\left(\mathrm{O}_{\mathrm{i}}\right)$ ou nitrogênio $\left(\mathrm{N}_{\mathrm{j}}\right)$ pertencentes à proteína. Assim, de modo geral, uma vizinhança é representada por um conjunto $\mathrm{V}=\left\{\mathrm{A}, \mathrm{D}, \mathrm{H}, \mathrm{O}_{1}, \ldots, \mathrm{O}_{\mathrm{m}}, \mathrm{N}_{1}, \ldots, \mathrm{N}_{\mathrm{n}}\right\}$, onde $m \geq 0$ e $n \geq 0$. Se $m=$ 0 , então não existem átomos receptores do tipo oxigênio na vizinhança e se $n=0$ não 
existem átomos receptores tipo nitrogênio. Conceitualmente, esta definição refere-se aos possíveis átomos formadores da ligação hidrogênio, mas ao longo deste trabalho os dados efetivamente usados serão as posições espaciais $x, y, z$ correspondentes a estes átomos ou listas de distâncias entre eles.

Tabela 4.1.1 Relação de aminoácidos com grupo OH na cadeia lateral (definição de átomos antecessor, doador e hidrogênio seguindo formato $P D B$ )

\begin{tabular}{|l|l|l|l|}
\hline \multicolumn{1}{|c|}{ aminoácido } & \multicolumn{1}{|c|}{ antecessor } & \multicolumn{1}{c|}{ doador } & \multicolumn{1}{c|}{ hidrogênio } \\
\hline Serina (SER) & CB & OG & HG \\
\hline Treonina (THR) & CB & OG1 & HG1 \\
\hline Tirosina (TYR) & CZ & OH & HH \\
\hline
\end{tabular}

O termo vizinhança foi escolhido (criado) no contexto deste trabalho apenas no sentido de expressar uma proximidade dos átomos envolvidos, não se tratando de um termo científico usado na literatura sobre ligações hidrogênio. Dois formatos de vizinhança foram definidos: esférico e toro. No formato esférico, os receptores são escolhidos dentro de uma esfera de raio dado $r$ centrada no átomo doador ${ }^{5}$ (fig. 4.1.1).

O comprimento da ligação covalente entre o doador (D) e o hidrogênio (H) é considerado fixo, bem como o ângulo ADH compreendido pelos átomos antecessor, doador e hidrogênio. Como a ligação covalente é simples, isto permite uma liberdade de rotação do átomo de hidrogênio em torno do eixo antecessor - doador, respeitando-se o comprimento I $\mathrm{DH}$ e o ângulo ADH. Vamos denominar esta trajetória circular de possíveis pontos onde o hidrogênio pode rotacionar de orbital no contexto desta dissertação, tomando-se o cuidado de não se confundir com os orbitais dos elétrons nos átomos, que é o que nos vem à lembrança quando falamos de orbitais em química. No formato toro, são escolhidos os receptores que estiverem a uma distância $r$ do orbital, isto é, dentro de um toro de raio $\mathrm{r}$ em torno do orbital do hidrogênio.

5 Observação: em nenhuma das figuras desta dissertação os átomos A, D e H são desenhados com os comprimentos de ligação e ângulos corretos do modelo físico real. São apenas representações grosseiras produzidas manualmente com fins apenas ilustrativos. 


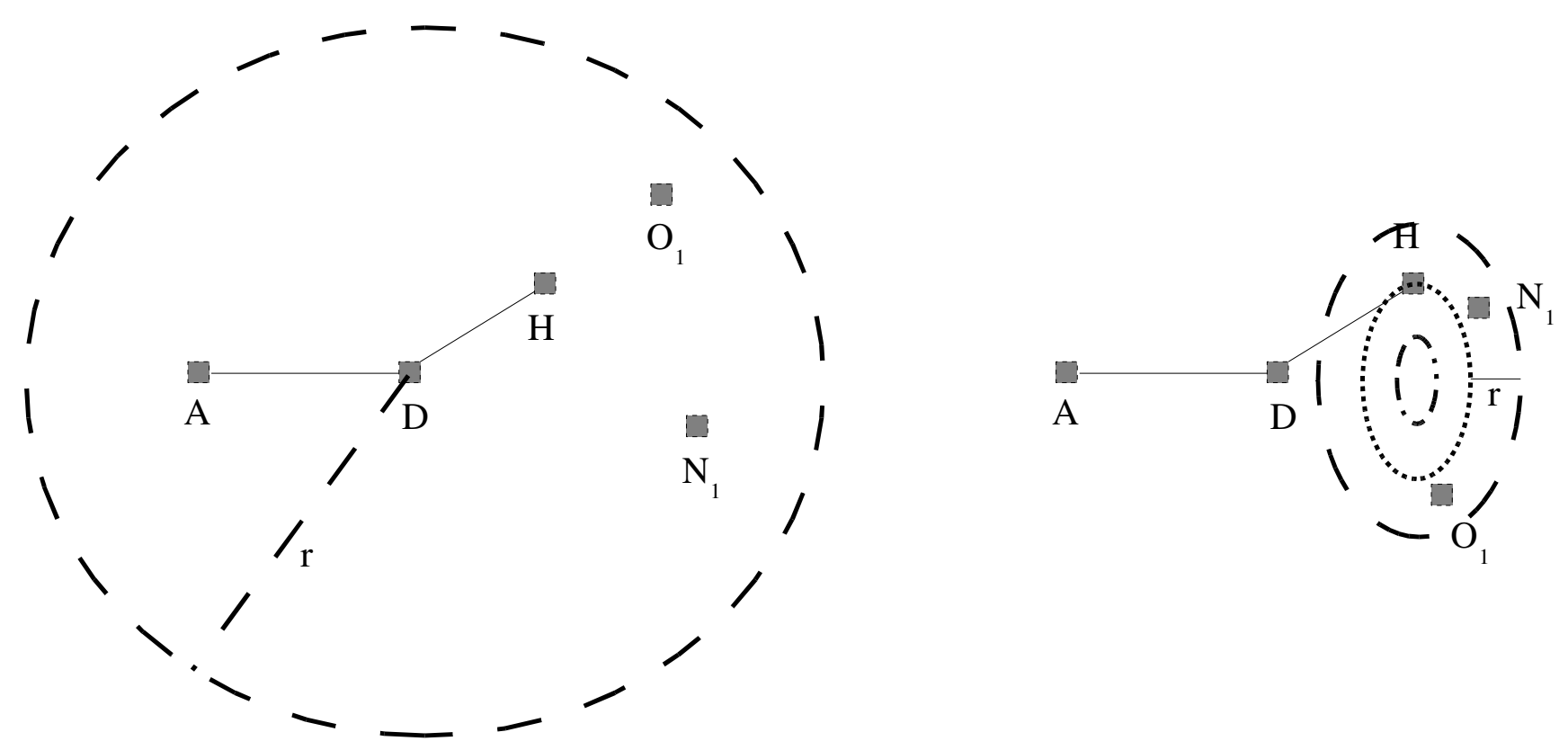

Figura 4.1.1 Vizinhanças nos formatos esfera e toro.

\subsubsection{Leitura de dados e geração de padrões de ligações hidrogênio}

Os dados são lidos de arquivos textos da base de dados PDB, obtidos em mídia DVD, versão 1 do ano de 2004. Um programa leitor lê e monta uma estrutura hierárquica de listas contendo: o modelo; cadeias do modelo; aminoácidos da cadeia; átomos (e suas coordenadas $\mathrm{x}, \mathrm{y}, \mathrm{z}$ ) dos aminoácidos (fig. 4.1.2). O programa foi desenvolvido em C++ e lê todos os arquivos textos contidos na base de dados. Para cada arquivo texto de entrada, toda vez que o programa leitor encontra um modelo de estrutura protéica, o programa monta um grid contendo os átomos dos aminoácidos lidos do modelo e a estrutura hierárquica de listas.

São lidos e armazenados na estrutura hierárquica apenas átomos que pertençam aos 20 tipos de aminoácidos para que o domínio da aplicação fique restrito às proteínas (o arquivo de entrada pode conter outros tipos de moléculas, que não sejam proteínas, ou átomos isolados). A seguir é criado um grid para indexar espacialmente os átomos do modelo para e acelerar a busca por átomos vizinhos. A estrutura hierárquica é percorrida $\mathrm{e}$ 
quando o aminoácido for serina, treonina ou tirosina é verificado se estão presentes os átomos antecessor, doador e hidrogênio conforme a tabela 4.1.1. Estes são os 3 aminoácidos que possuem um grupo hidroxila $(\mathrm{OH})$ na cadeia lateral. Se os 3 átomos estiverem presentes, então em função do formato de vizinhança escolhido e de um raio predeterminado é feita a busca no grid dos átomos oxigênio e nitrogênio contidos na vizinhança. É feita uma nomeação dos átomos receptores e os dados da vizinhança são adicionados no arquivo texto de saída apropriado.

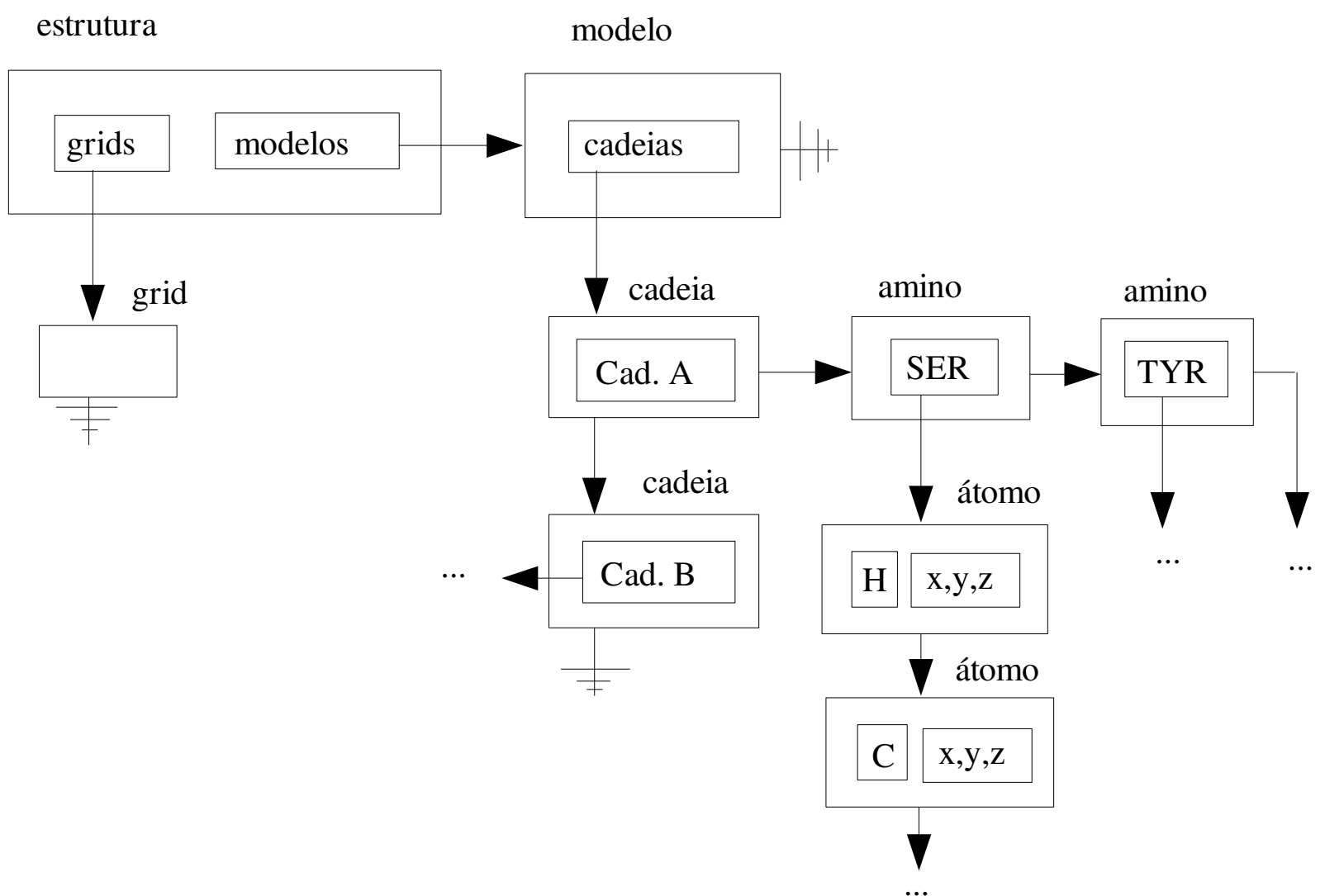

Figura 4.1.2 Estrutura hierárquica de listas de objetos.

Cada arquivo de saída armazena vizinhanças contendo um número constante de possíveis receptores oxigênio e de possíveis receptores nitrogênio. Por exemplo, se o programa lê uma vizinhança com 2 oxigênios, o arquivo de saída adequado é o que contém vizinhanças com 2 oxigênios e nenhum nitrogênio. Se um aminoácido de interesse não contiver no arquivo de entrada os 3 átomos (antecessor, doador e hidrogênio) sua 
vizinhança não é gerada.

Após o término da leitura de um modelo, o programa desaloca a memória utilizada para armazenar a estrutura hierárquica e o grid, e se houver um novo modelo no arquivo de entrada o processo é repetido até o fim da leitura do arquivo de entrada. Lembremos que para estruturas resolvidas pelo método NMR existem até dezenas de modelos.

Os arquivos de saída contêm os padrões de ligações hidrogênio de toda a base lida, e não apenas de um único arquivo de entrada. Um exemplo de uma vizinhança contendo apenas um receptor oxigênio é mostrado a seguir. A primeira linha identifica o arquivo e o modelo, as linhas seguintes identificam os átomos hidrogênio, antecessor e doador e suas coordenadas, os átomos receptores oxigênio, os átomos receptores nitrogênio, listas de distâncias entre os átomos (valor -1 quando a lista for vazia) e a última lista anota o neurônio que será associado a um grupo no algoritmo de agrupamento.

\{arquivo id.pdb, número do modelo, número de átomos, número de oxigênios, número de nitrogênios\}

entrada: pdb 1ufm.pdb modelo 1 nroAtomos 4 receptorO 1 receptorN $O$

\{número do átomo, nome do átomo, tipo do átomo, cadeia, tipo do aminoácido, posição do aminoácido na cadeia, coordenadas $\mathrm{x}, \mathrm{y}, \mathrm{z}$ do átomo

1 HG H cad A res SER 290 coord -14.022 16.235 4.427 \{hidrogênio\}

2 CB C cad A res SER 290 coord -15.732 15.347 3.886 \{antecessor\}

3 OG O cad A res SER 290 coord -14.809 16.432 3.843 \{doador\}

4 O O cad A res SER 290 coord -13.714 13.3773.769 \{receptor oxigênio\}

1.425 \{distância antecessor - doador

2.823 \{distâncias antecessor - oxigênios \}

-1 distâncias antecessor - nitrogênios $\}$

3.246 \{distâncias doador - oxigênios\}

-1 distâncias doador - nitrogênios $\}$

-1 \{distâncias oxigênios - oxigênios\}

-1 \{distância nitrogênios- nitrogênios\}

-1 distâncias oxigênios - nitrogênios

2.001 distância antecessor - hidrogênio\} 
Capítulo 4 Modelagem do problema

1.000 \{distância doador - hidrogênio $\}$

2.949 \{ distâncias hidrogênio - oxigênios

-1 \{distância hidrogênio - nitrogênios \}

neuronio -1 -1 \{neurônio vencedor quando for usado rede neural SOM para agrupamento de dados $\}$

\subsubsection{Grid para mapeamento de átomos próximos}

O grid é construído como uma matriz tridimensional cujas células são vetores alocados dinamicamente para economizar memória. Sabendo-se a priori (percorrendo todos os átomos da estrutura hierárquica) que o menor e o maior valor das coordenadas $x, y, z$ de quaisquer dos átomos do modelo são respectivamente $\min X, \min Y, \min Z$ e $\max X, \max Y$, $\max Z$, determina-se inicialmente a quantidade de células (comprimento do vetor) em cada dimensão da matriz, usando o diâmetro do maior dos átomos (enxofre) contido nos aminoácidos como a largura da célula do grid. Assim temos que:

- comprimentoX $=(\max X-\min X) /$ diâmetro_enxofre;

- comprimentoY $=(\max Y-\min Y) /$ diâmetro_enxofre;

- comprimentoZ $=(\max Z-\min Z) /$ diâmetro_enxofre.

Cada vez que um átomo de coordenadas $x, y, z$ deve ser inserido no grid, o seguinte procedimento é executado:

1) Os índices $i, j, k$ correspondentes à celula do grid que deve conter o átomo são calculados:

- $\quad i=(x-\min X) /$ diâmetro_enxofre

- $j=(y-\min Y) /$ diâmetro_enxofre

- $\quad k=(z-\min Z) /$ diâmetro_enxofre

2)Se ainda não existe o vetor da dimensão $x$ (matriz $=$ nulo $)$, então é alocado um vetor de tamanho comprimentoX. Este vetor tem suas células inicialmente anuladas (valor de ponteiro de memória é iniciado com valor nulo). Se ainda não existe o vetor da dimensão $y($ matriz $[i]=$ nulo $)$ é alocado um vetor de tamanho comprimentoY para a posição $i$ do vetor da dimensão $x$ e o valor de matriz[i] deixa de ser nulo. Este novo vetor da dimensão $y$ (matriz[i]) tem suas células inicialmente anuladas. Se ainda não existe o vetor da dimensão $z$ (matriz $[i, j]=$ nulo) então é alocado um vetor de tamanho comprimentoZ para a posição $j$ do vetor da dimensão y e o valor de matriz[i,j] deixa de ser nulo. Esta matriz constituída de 
vetores é ilustrada na figura 4.1.3.

3)Uma referência (ponteiro) para o átomo de coordenadas $x, y, z$, é inserida na lista de objetos contida na célula matriz[i,j,k].

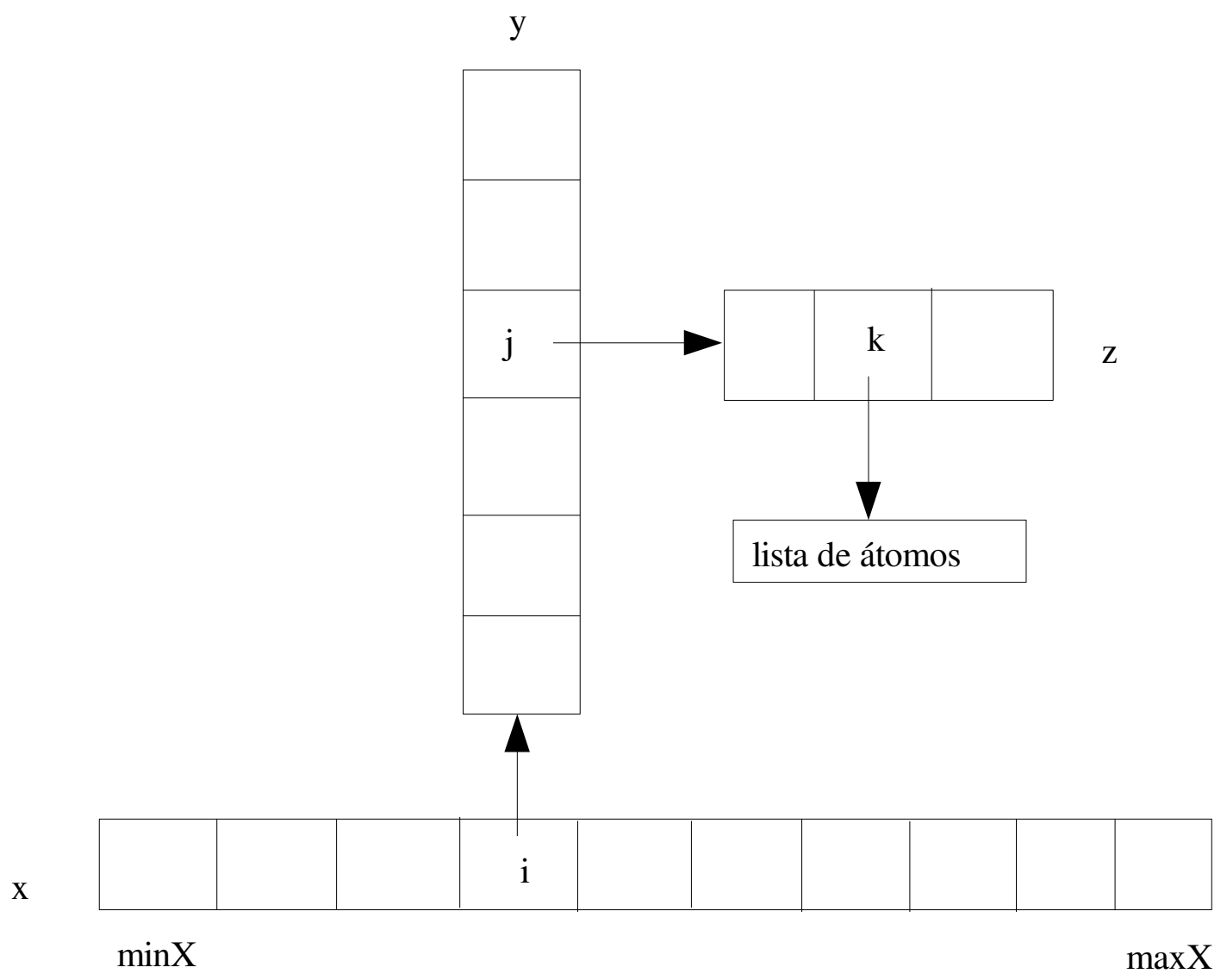

Figura 4.1.3 Grid para indexação espacial de átomos. 


\subsubsection{Vizinhança esférica}

Para a vizinhança esférica, dado como centro o átomo doador (D) com coordenadas $x_{1}, y_{1}, z_{1}$ e um raio $r$, podemos escolher no grid o cubo que contém a esfera. Este cubo é composto de todas as células de índices $i, j, k$ contidas no cubo, cujas coordenadas $x, y, z$ representadas pelas células pertencem aos intervalos $\left[x_{1}-r, x_{1}+r\right],\left[y_{1}-r, y_{1}+r\right]$ e $\left[z_{1}-r, z_{1}\right.$ $+r$ ], respectivamente. Então para cada objeto com coordenadas $x_{2}, y_{2}, z_{2}$ contidos nas células do cubo, testamos se a distância do objeto ao átomo doador é menor ou igual a $r$, caso em que o objeto está contido na esfera; se a distância for maior que $r$ o objeto está fora da esfera e portanto não é incluído na vizinhança.

\subsubsection{Vizinhança em toro}

Vamos considerar as seguintes representações para operações com vetores: $\langle\mathbf{A} \rightarrow \mathbf{B}>$ denota o representante de posição do vetor com origem no ponto $A=\left(x_{A}, y_{A}, z_{A}\right)$ e destino no ponto $B=\left(x_{B}, y_{B}, z_{B}\right) ; \boldsymbol{u}<\boldsymbol{v}>$ denota o representante de posição do vetor unitário do vetor $\boldsymbol{v}=$ $\left.<x_{v}, y_{v}, z_{v}\right\rangle$; $|\boldsymbol{v}|$ denota o comprimento do vetor $\boldsymbol{v} ; A+\boldsymbol{v}=R$ denota a soma do vetor $\boldsymbol{v}$ ao ponto $A$ resultando no ponto $R$, isto é, o representante de posição do vetor $v$ com origem em $A$ e destino em $B, \operatorname{com} A=\left(x_{A}, y_{A}, z_{A}\right), v=\left\langle x_{v}, y_{v}, z_{v}>\right.$ e $R=\left(x_{A}+x_{v}, y_{A}+y_{v}, z_{A}+z_{v}\right)$.

Para a vizinhança com formato de toro com raio $r$ em torno do orbital do hidrogênio $\mathrm{H}$, podemos considerar primeiro a esfera de raio $R$ que envolve o toro, centrada no centro do toro (fig. 4.1.4), e depois o cubo que envolve a esfera. Depois que recuperamos os objetos do grid que pertencem às células do cubo, testamos se pertencem ao toro.

Para determinar a esfera que envolve o toro, precisamos antes calcular o ponto $C$ que é o centro do orbital do hidrogênio e o raio h do orbital (fig. 4.1.4).

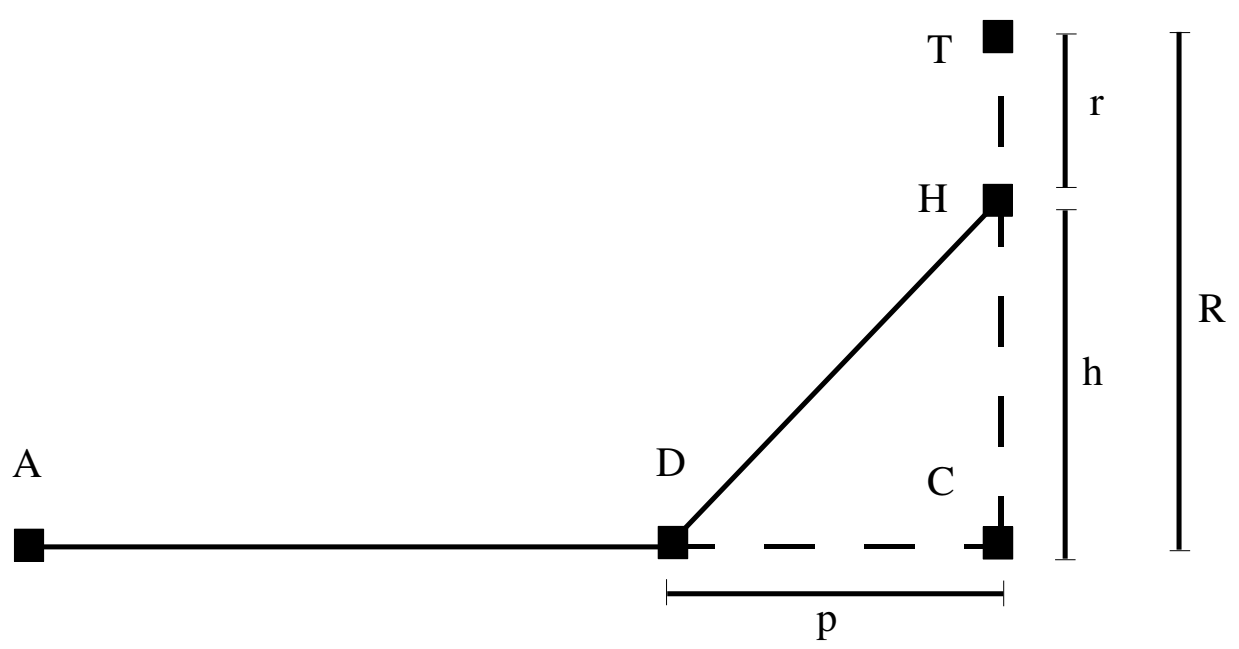

Figura 4.1.4 Cálculo do centro do toro. 
Para calcularmos o ponto $C$, determinamos a distância $p=|<D \rightarrow C>|$ que corresponde à projeção escalar de $\langle D \rightarrow H>$ sobre $\langle D+u<A \rightarrow D>$. Calculamos o ponto $C=D+$ p.u<A $\rightarrow D>$. O raio $R=|<C \rightarrow T>|$ da esfera centrada no ponto $C$ que envolve o toro é $R=h$ $+r$, onde $h=\mid\langle C \rightarrow H>|$ e $r$ é o raio dado do toro. O cubo que envolve a esfera de raio $R$, que envolve o toro de raio r, que envolve o orbital do hidrogênio $(H)$ com centro no ponto $C=\left(x_{C}, y_{C}, z_{C}\right)$, é o cubo composto de todas as células do grid de índices $i, j, k$ contidas no cubo cujas coordenadas $\mathrm{x}, \mathrm{y}, \mathrm{z}$ pertencem aos intervalos $\left[\mathrm{x}_{\mathrm{C}}-\mathrm{R}, \mathrm{x}_{\mathrm{C}}+\mathrm{R}\right],\left[y_{C}-R, y_{C}+R\right],\left[z_{C}\right.$ $\left.-R, z_{C}+R\right]$, respectivamente.

Dados os átomos receptores $R=\left(x_{R}, y_{R}, z_{R}\right)$ contidos nas células do cubo que envolve o toro, precisamos ainda determinar quais destes objetos pertencem ao toro para determinar a vizinhança. Vamos considerar o plano que contém os átomos antecessor $(A)$, doador $(D)$ e o receptor $(R)$ sendo analisado (fig. 4.1.5). Este plano intercepta o orbital do hidrogênio no ponto $H_{\text {aux }}$, que é a posição do orbital mais próxima de $R$. Para calcularmos o ponto $C_{R}$, determinamos a distância $q=\left|<D \rightarrow C_{R}>\right|$ que corresponde à projeção escalar de $\langle D \rightarrow R>$ sobre $<D+u<A \rightarrow D>>$. Calculamos o ponto $C_{R}=D+q \cdot u<A \rightarrow D>$. Calculamos o ponto $H_{a u x}=C+h \cdot u<C_{R} \rightarrow R>$. Lembrando que $H_{a u x}$ é o ponto do orbital mais próximo de $R$ e $r$ é o raio do toro, $R$ está contido no orbital se $\left|<H_{\text {aux }} \rightarrow R>\right| \leqslant r$.

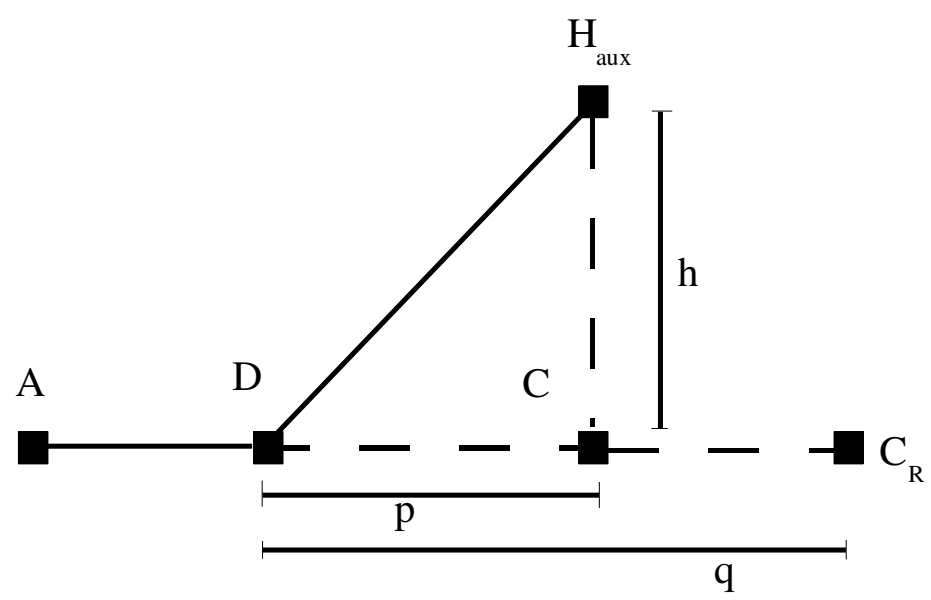

Figura 4.1.5 Plano contendo antecessor, doador e receptor que intercepta o orbital de hidrogênio. 
Capítulo 4 Modelagem do problema

\subsection{Agrupamento de padrões}

\subsubsection{Necessidade do agrupamento de padrões}

Uma rede neural multicamadas implementa a aproximação de uma função calibrando os parâmetros livres da rede iterativamente através da minimização dos erros entre os valores de saída calculados e os desejados para os valores de entrada dos padrões, como vimos na seção 3.1.3. O sucesso desta operação depende da qualidade dos dados de treinamento e validação (desejamos não haver ruído nos dados, continuidade da função mapeada, uma amostragem com distribuição uniforme sobre os espaços de entrada e saída), da arquitetura da rede (não sabemos a configuração ideal a priori, uma rede muito grande memoriza os dados ao invés de generalizar a função, uma rede muito pequena pode ser incapaz de implementar uma função muito complexa) e do processo de treinamento (escolha inicial e atualização de: pesos das conexões, parâmetros da função de limiar, escolha da função de erro, taxas de aprendizado e momento, determinação do melhor momento para encerrar o treinamento e obter-se o máximo de generalização evitando-se o overfitting).

De "modo geral", podemos dizer que problemas de classificação são mais fáceis de serem solucionados do que problemas de aproximação. Em um problema de classificação, a função implementada funciona como um hiperplano de separação de regiões, fornecido um dado de entrada, a rede precisa mapeá-lo em uma região do espaço de saída. Em um problema de aproximação, a função implementada funciona como um interpolador e fornecido um dado de entrada a rede precisa mapeá-lo em um único ponto do espaço de saída. Visivelmente é mais provável a chance de sucesso de um ponto pertencer a uma região do que fazer-se o casamento preciso de dois pontos (fig. 4.2.1). Observe que como não sabemos sobre a distribuição dos dados, podem haver regiões vazias sem a representação de padrões.
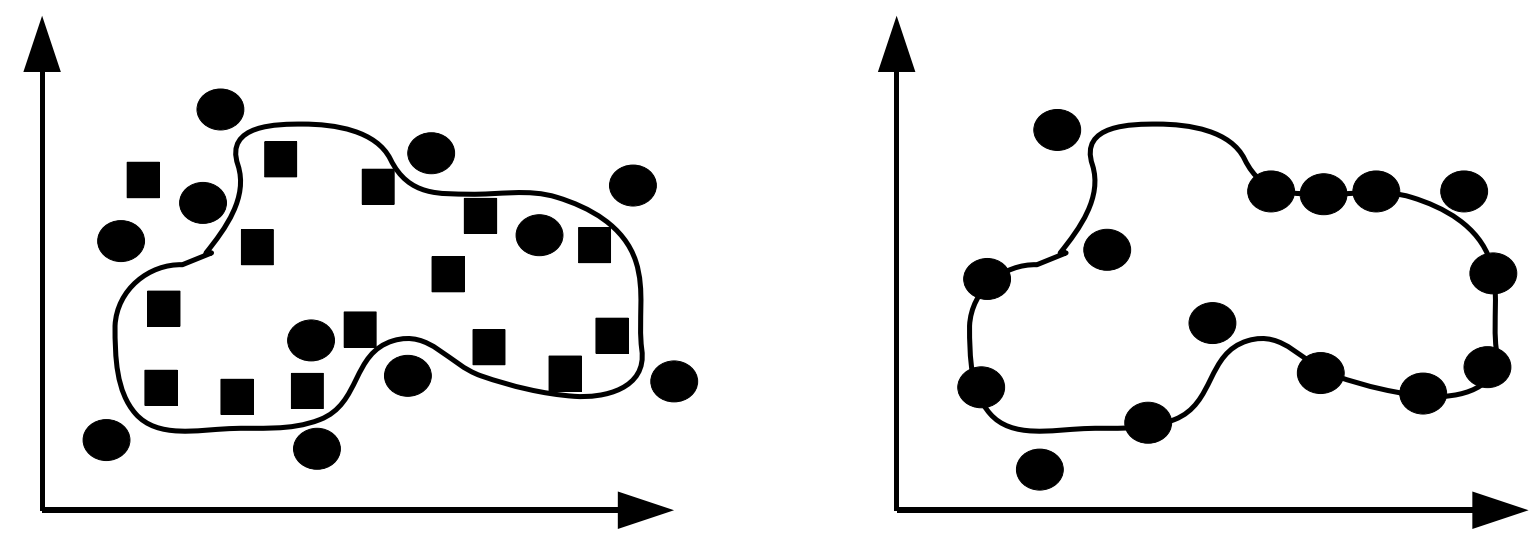

Figura 4.2.1 Problemas de classificação e aproximação. 
A proposta desta dissertação é a previsão de um átomo de hidrogênio (coordenadas $x, y, z)$ a partir das posições dos átomos antecessor, doador e receptores da ligação hidrogênio. Vamos considerar o menor caso em que há apenas um receptor, assim temos 3 átomos de entrada com 3 coordenadas $\mathrm{x}, \mathrm{y}, \mathrm{z}$ cada um, totalizando 9 parâmetros de entrada (vamos chamá-los de $w_{i}$ ) e precisamos mapear as 3 coordenadas do hidrogênio:

- $f_{l}\left(w_{1}, \ldots, w_{9}\right)=x$

- $f_{2}\left(w_{1}, \ldots, w_{9}\right)=y$

- $f_{3}\left(w_{1}, \ldots, w_{9}\right)=z$

O espaço dos dados de entrada e saída são um subconjunto dos números reais, uma vez que as coordenadas dos átomos fazem parte da região do espaço que a proteína ocupa em $R_{3}$. Não é preciso muito esforço para imaginar que estas funções com 9 parâmetros de entrada (no menor caso) não devem ser triviais. Há uma grande disponibilidade de dados de entrada (o que é ótimo) mas como estes dados são obtidos experimentalmente, é difícil fazer qualquer afirmação sobre a qualidade dos mesmos. Certamente é possível fazer-se uma análise e filtragem dos mesmos usando-se métodos estatísticos, computacionais, aplicação de restrições baseadas em conhecimentos fisicoquímicos e consideração dos parâmetros aplicados e registrados nos experimentos. Também é certo que esta é uma atividade complexa, além do escopo que este trabalho se propõe.

Assim, na esperança de obter-se resultados mais satisfatórios, ao invés de se treinar uma única rede neural com todos os padrões disponíveis, optou-se pela agrupamento dos padrões por similaridade, e criação de uma rede neural para cada agrupamento, tendo-se muitas soluções especializadas ao invés de uma solução genérica. Imagina-se que os agrupamentos com maior tamanho representem os padrões com maior frequência de ocorrência (mas também podem apresentar maior redundância), apresentem melhor treinamento da rede em função da quantidade disponível de dados, enquanto agrupamentos pequenos representem padrões bizarros ou com ruídos, de baixa ocorrência. Assim, os agrupamentos maiores, representantes dos padrões mais frequentes, devem conduzir a melhores resultados nas previsões. A figura 4.2.2 ilustra os grupamentos como faixas, onde cada faixa corresponderia a uma rede neural. As áreas vazias representam regiões onde não há amostragem de dados.

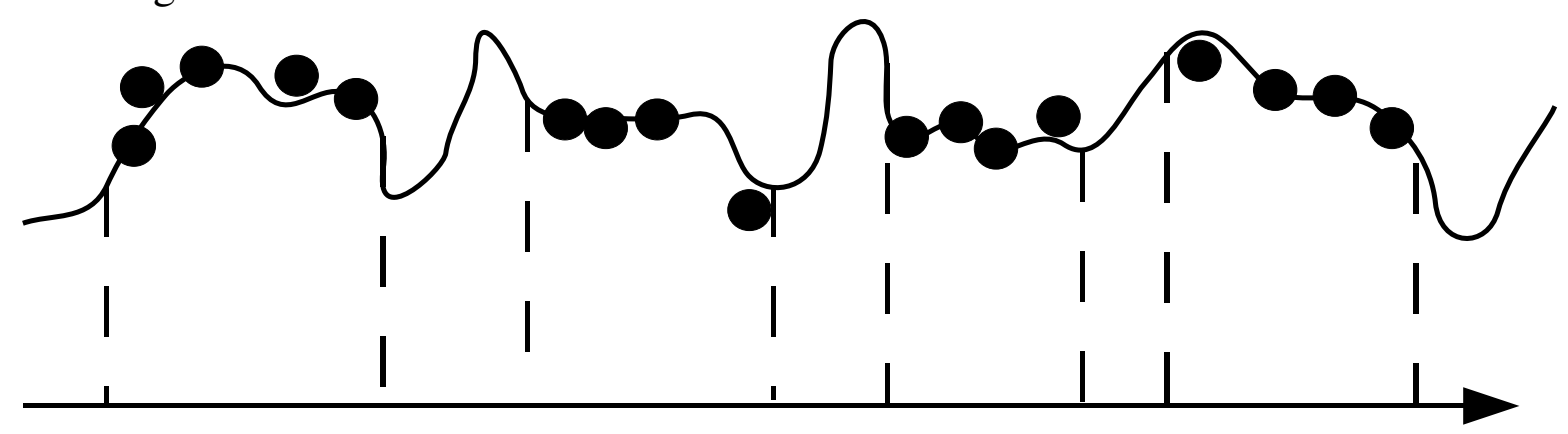

Figura 4.2.2 Regiões da função que possuem amostras de dados a serem aproximadas por redes neurais. 


\subsubsection{Nomeação de receptores}

O conhecimento que temos sobre a modelagem dos receptores até o momento é que eles estão localizados espacialmente dentro de uma vizinhança, são átomos do tipo oxigênio ou nitrogênio representados pelas listas $O_{1}, \ldots, O_{m} \mid m \geq 0$ e $N_{l}, \ldots, N_{n} \mid n \geq 0$ respectivamente; $m$ $=0$ significando a inexistência de receptores oxigênio e $n=0$ significando a inexistência de nitrogênios.

Os átomos antecessor, doador e hidrogênio são únicos para cada vizinhança, portanto facilmente identificáveis. Precisamos estabelecer algum critério para identificar (nomear com $O_{i} s$ e $N_{i} s$ ) cada um destes receptores para atender 3 finalidades: comparar 2 vizinhanças e agrupá-las por similaridade; superpor 2 vizinhanças similares; fornecer as coordenadas dos receptores correspondentes, pertencentes à vizinhanças (padrões) distintas, na posição correta do vetor de entrada da rede neural para não confundir o treino da rede.

\subsubsection{Nomeação por projeção escalar}

O critério mais simples inicialmente implementado para nomear os receptores corresponde a 'fatiar' a vizinhança perpendicularmente em relação ao eixo antecessordoador e numerar progressivamente os receptores à medida que são encontrados na 'fatia' atualmente cortada.

No caso da vizinhança esférica sabemos por construção que o doador $(D)$ é o centro da esfera de raio $r$. A partir do vetor $\langle A \rightarrow D\rangle$ podemos construir o vetor $\langle I \rightarrow F\rangle$ de comprimento $2 r$ com a mesma direção e sentido que o vetor $\langle A \rightarrow D\rangle$, com o ponto médio coincidindo com o ponto $D$, o início $I$ na metade do diâmetro que contém o ponto $A$ e o fim $F$ do outro lado. Conseguimos isto fazendo $I=D-r \cdot u<A \rightarrow D>, F=I+2 r \cdot u<A \rightarrow D>$ (fig. 4.8).

Para cada átomo receptor oxigênio $\mathrm{O}_{\mathrm{x}}$, podemos criar o vetor $<\mathrm{I} \rightarrow \mathrm{O}_{\mathrm{x}}>$ e projetarmos no vetor $\langle\mathrm{I} \rightarrow \mathrm{F}>$ como mostrado na figura 4.2.3, onde as projeções são o ponto de encontro da linha tracejada, perpendicular ao vetor $\langle\mathrm{I} \rightarrow \mathrm{F}>$ que passa por um átomo receptor, com o vetor $\langle\mathrm{I} \rightarrow \mathrm{F}\rangle$. Em função do valor das projeções (de zero a 2r) no vetor $\langle\mathrm{I} \rightarrow \mathrm{F}\rangle$, podemos ordenar os átomos como $\mathrm{O}_{1}, \mathrm{O}_{2}, \ldots, \mathrm{O}_{\mathrm{n}}$ considerando a ordem em que as projeções incidem no vetor $\langle\mathrm{I} \rightarrow \mathrm{F}\rangle$. Desta forma, temos um critério para ordenar os átomos receptores 
oxigênio contidos dentro de uma vizinhança. O mesmo critério é usado para ordenar os receptores nitrogênio.
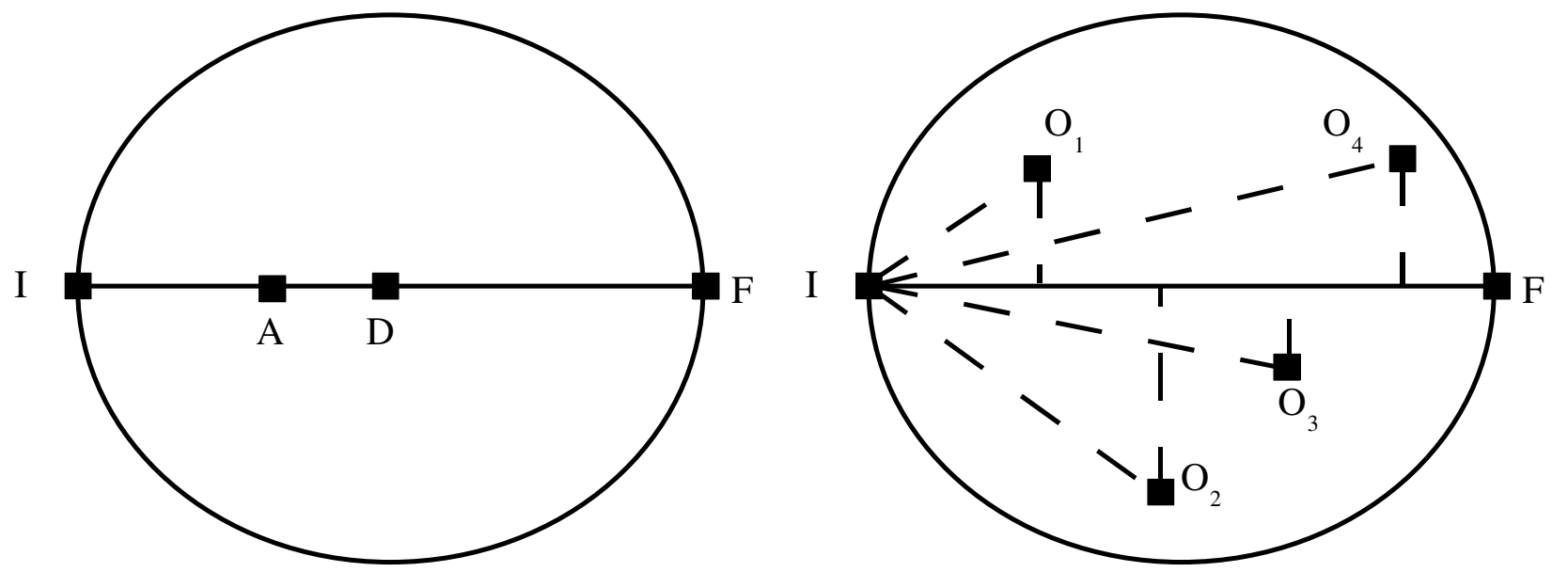

Figura 4.2.3 Nomeação por projeção escalar.

Este procedimento permite nomear os receptores sem considerar a posição do hidrogênio e é muito rápido computacionalmente, pois exige poucos cálculos. Porém esta simplicidade, reduzindo a ordenação de um dado tridimensional para somente uma dimensão, posteriormente revelou a possibilidade de causar falhas em atender aos objetivos posteriores de agrupamento e superposição.

Um dos problemas com esta abordagem é que se tivermos duas vizinhanças similares A e B, com dois ou mais receptores de um mesmo tipo com projeções escalares no eixo $<\mathrm{I} \rightarrow \mathrm{F}>$ com valores parecidos mas não na mesma ordem (em 'discos' próximos, mas trocados), apesar de haver correspondência espacial entre as duas vizinhanças, após a ordenação esta correspôndência é perdida (fig. 4.2.4).
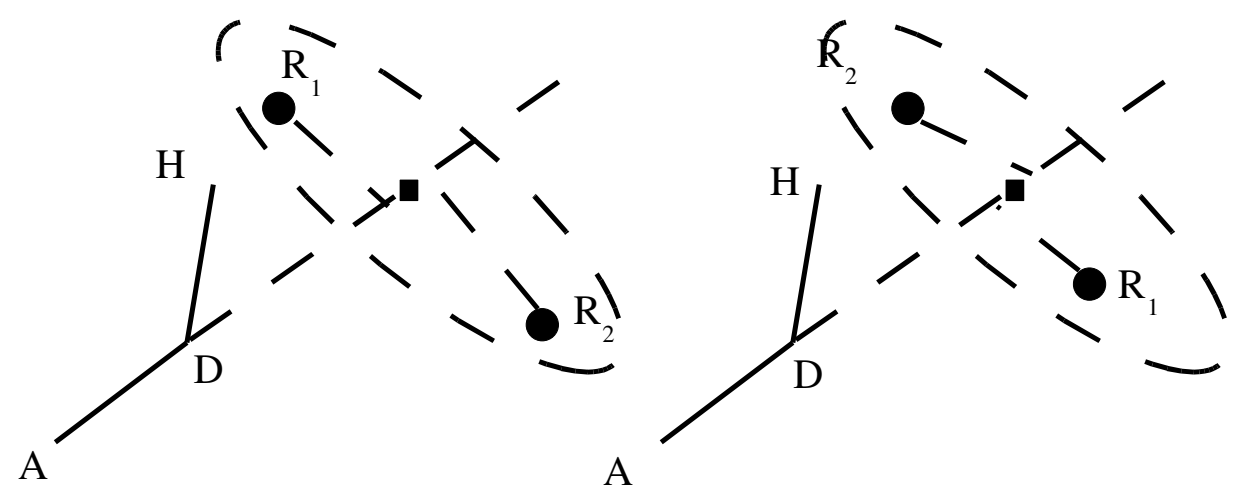

Figura 4.2.4 Nomeação errada de receptores correspondentes por projeção e scalar.

Outro problema é quando temos dois ou mais receptores próximos a um mesmo disco em duas vizinhanças, mas sem similaridade espacial. Como ordenar estes receptores 
Capítulo 4 Modelagem do problema

(fig. 4.2.5)?
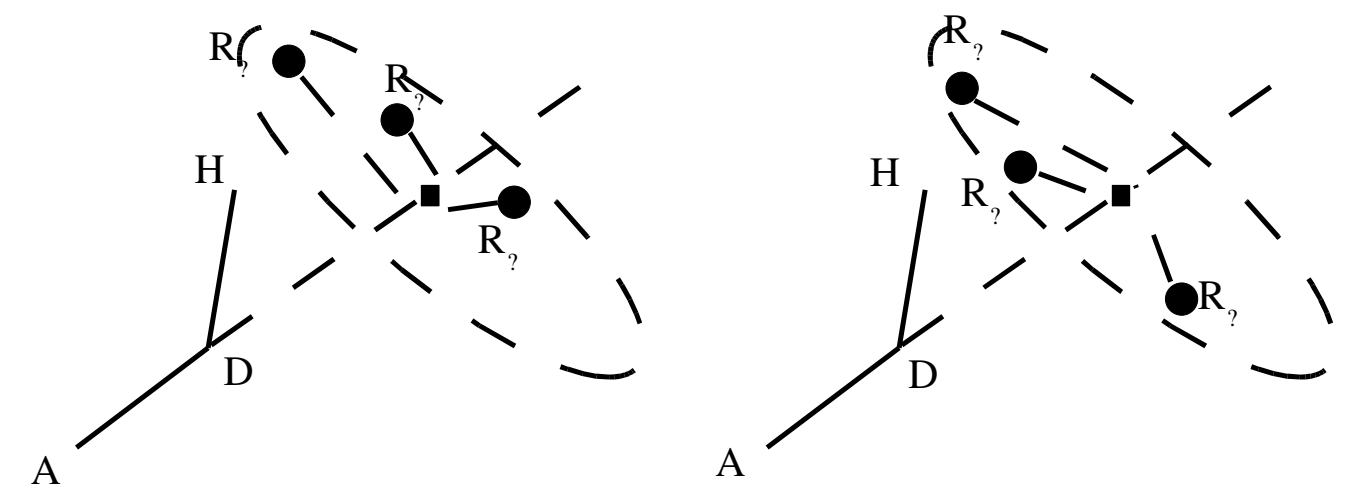

Figura 4.2.5 Receptores em um mesmo disco de duas vizinhanças sem correspondência.

\subsubsection{Nomeação por setorização}

Dados os problemas com a nomeação por projeção escalar, pensou-se em dividir espacialmente a vizinhança em setores ordenados $S_{i}$, e então ordenar-se os receptores em função do setor a que pertencem (fig 4.2.6). O conteúdo desta seção refere-se apenas à vizinhança em toro.
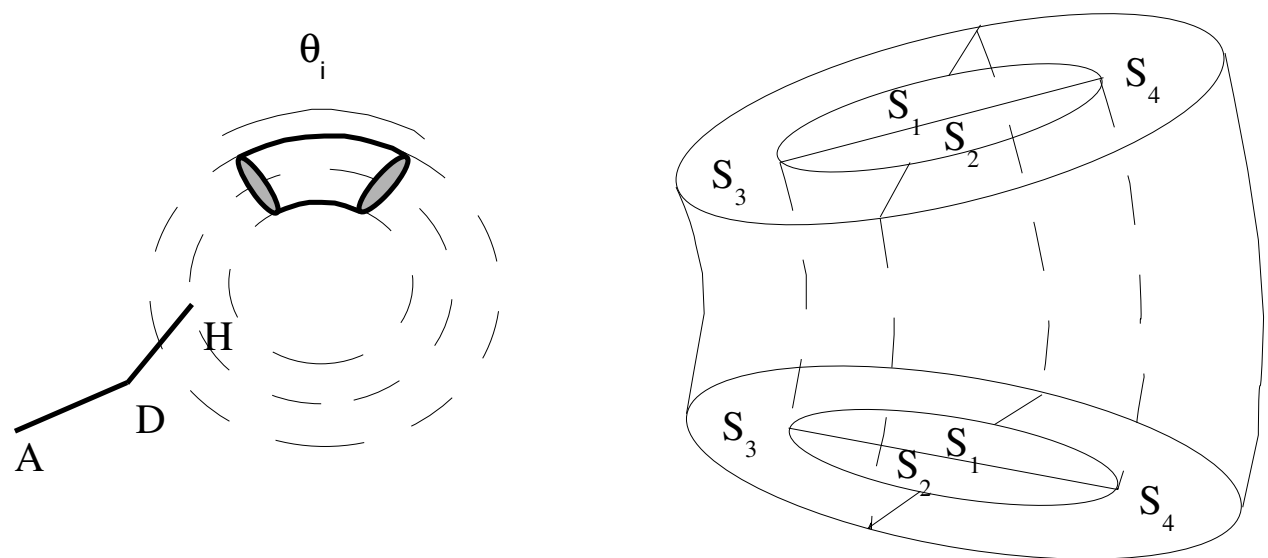

Figura 4.2.6 Divisão do toro em anéis, e de cada anel em setores.

Este tipo de divisão considerando regiões espaciais permite um mapeamento mais 
detalhado que o da nomeação por projeção escalar, porém continua apresentando problemas, principalmente quando há duas vizinhanças semelhantes em que os receptores correspondentes ficam em regiões próximas a borda dos setores. Para exemplificar isto, vamos supor que o toro é constituído de vários toros concêntricos ao orbital do hidrogênio (trilhas) numeradas progressivamente do centro (orbital do hidrogênio) para a lateral do toro, e que cada trilha é dividida em um certo número de regiões (setores). O toro também é dividido em anéis de igual tamanho, com um ângulo $\theta$ em relação ao centro do toro. A ordenação de um receptor obedece à ordem anel, trilha, setor. $\mathrm{O}$ anel é mostrado na fig. 4.2.6. A figura 4.2.7 mostra um corte transversal de um anel de 3 trilhas, representando 2 vizinhanças similares, mas com erro na nomeação de receptores correspondentes às vizinhanças.
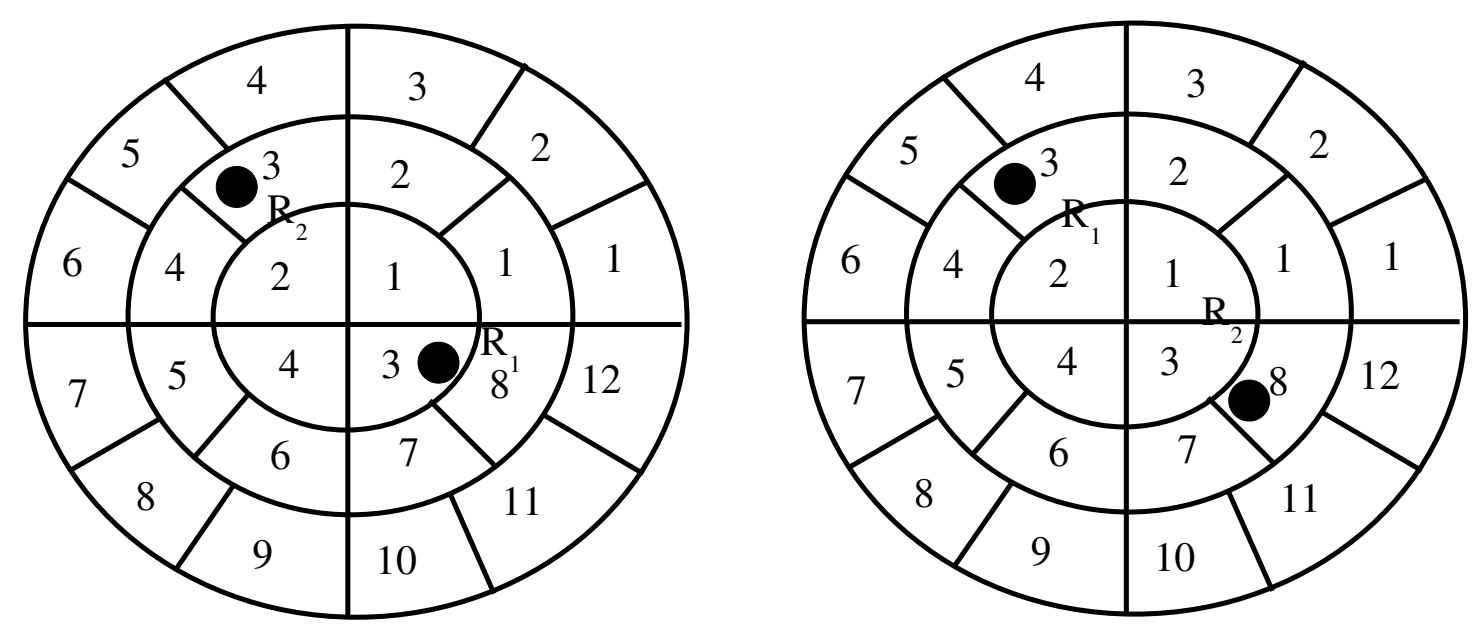

Figura 4.2.7 Na vizinhança à esquerda o receptor $R 1$ está na trilha 1 , setor 3 e o receptor $R 2$ na trilha 2, setor 3. Na vizinhança à direita o receptor $R 1$ está na trilha 2 , setor 3 e o receptor $R 2$ na trilha 2 , setor 8. Mas fisicamente, os receptor $R 1$ e $R 2$ da vizinhança à esquerda correspondem aos receptores $R 2$ e R1 da vizinhança à direita, respectivamente. Assim houve perda de correspondência da proximidade fisica entre receptores após a etiquetação.

\subsubsection{Nomeação por paridade de vizinhanças}

As tentativas de segmentar a vizinhança em regiões e ordenar os receptores em função da região a que pertencem mostrou-se falha. A causa deste insucesso é que pontos pertencentes a duas vizinhanças distintas (correspondentes em proximidade física quando estas vizinhanças são superpostas), se estiverem na borda das regiões, de um lado da borda 
em uma vizinhança, mas do outro lado da borda na outra vizinhança, podem receber ordenações muito diferentes e perderem a correspondência (quando as vizinhanças são superpostas).

O erro deste procedimento é tentar-se estabelecer um critério genérico de nomeação baseado exclusivamente nos referenciais de uma vizinhança isolada, não se considerando os dados da(s) outras(s) vizinhança(s) cujos pontos deseja-se estabelecer uma correspondência. A busca deste critério genérico é muito atraente, uma vez que os receptores de cada vizinhança são nomeados uma única vez, pois todos os referenciais são obtidos da própria vizinhança.

A solução encontrada para contornar este problema foi considerar os dados de duas vizinhanças para as quais se deseja estabelecer uma correspondência. Isto significa que dado um conjunto de $n$ vizinhanças, para cada possível par de duas vizinhanças distintas é preciso executar o processo de nomeação isoladamente. Assim, por exemplo, se nomearmos os receptores das vizinhanças $A$ e $B$, a nomeação já feita dos receptores de $A$ para o par $(A, B)$ é inválida para o par $(A, C)$. Precisa-se executar novamente o processo e obter-se uma nomeação específica dos receptores de $A$ (e de $C$ ) para o par $(A, C)$. Vamos denominar o algoritmo proposto para realizar este processo de 'nomeação por paridade de vizinhanças'.

A nomeação por paridade de vizinhanças (com o mesmo número de receptores oxigênio e de receptores nitrogênio) consiste na superposição de duas vizinhanças $F$ e $G$ e da associação de cada receptor da vizinhança $\mathrm{F}$ com o receptor mais próximo da vizinhança G. Inicialmente, é feito um alinhamento simples entre as 2 vizinhanças, fazendo-se as seguintes operações sobre elas (fig. 4.2.8): translação de modo que o centro $C$ do orbital do hidrogênio coincida com a origem dos eixos coordenados; rotações em torno dos eixos $x$ e $z$ de modo que o vetor $\langle A$ (ntecessor) $\rightarrow D$ (oador) $>$ fique posicionado no lado positivo do eixo $y$; rotação em torno do eixo $y$ de modo que o $H$ (idrogênio) fique posicionado no eizo $z$.

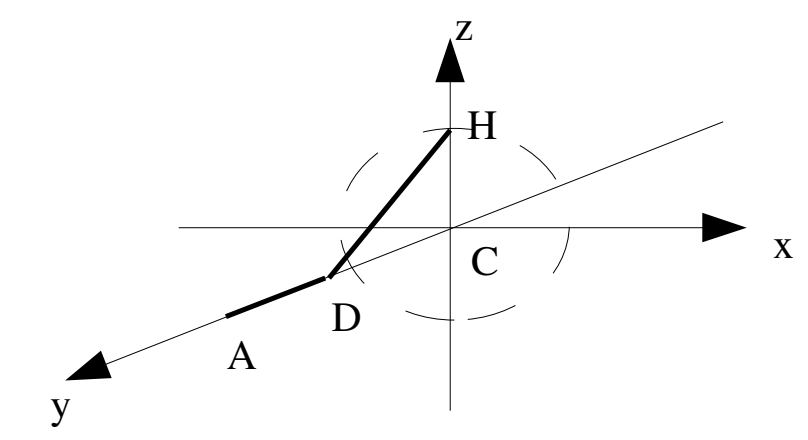

Figura 4.2.8 Posicionamento de vizinhança para alinhamento simples. 
Para cada receptor $O_{i}$ (do tipo oxigênio) da vizinhança $F$, são anotados o receptor $O_{j}$ da vizinhança $G$ mais próximo de $O_{i}$ e a distância entre $O_{i}$ e $O_{j}$. O par $\left(O_{i}, O_{j}\right)$ com a menor distância anotada é escolhido como uma correspondência e reservado. Como o receptor $O_{j}$ de $G$ foi reservado, se houver algum outro $O_{k}, k \neq i$, da vizinhança $F$ com o mesmo $O_{j}$ de $G$ anotado, é preciso procurar um novo receptor $O_{m}$ de $G, m \neq j$, que seja o mais próximo de $O_{k}$ e anotar $O_{m}$ e a distância $\left|O_{k} O_{m}\right|$ para o receptor $O_{k}$. Considera-se temporariamente $O_{\mathrm{i}}$ excluído de $F$ e $O_{j}$ excluído de $G$, até que sejam formados todos os pares de correspondência. Escolhe-se o um novo receptor $O_{i}$ de $F$ com a menor distância anotada ao novo receptor $O_{j}$ de $G$. Este novo par $\left(O_{i}, O_{j}\right)$ é uma nova correspondência e vai para os pares reservado. Repete-se o processo até não haver mais receptores para serem pareados. $\mathrm{O}$ conjunto de pares reservados são o resultado do mapeamento dos receptores da vizinhança $F$ para seus receptores correspondentes mais próximos na vizinhança $G$.

\subsubsection{Uso de distância para busca de similaridade entre vizinhanças}

Dado um conjunto de vizinhanças com a mesma composição (mesmo número de receptores oxigênio, mesmo número de receptores nitrogênio), desejamos um método que permita agrupar estas vizinhanças, de forma que o arranjo espacial dos átomos sejam similares (quando alinhadas estruturalmente). Se tentarmos usar como atributo diretamente as coordenadas espaciais dos átomos não teremos sucesso, uma vez que não sabemos a priori como as vizinhanças estão deslocadas/rotacionadas umas em relação às outras. Se considerarmos duas vizinhanças com a mesma quantidade $m$ de receptores oxigênio e mesma quantidade $n$ de receptores nitrogênio, e soubermos para cada átomo receptor de uma vizinhança qual o átomo correspondente da outra, podemos saber se o arranjo espacial das vizinhanças é similar através da comparação das distâncias correspondentes entre os átomos, que independe de como a vizinhança esta deslocada/rotacionada. Através do procedimento de nomeação dos receptores, temos uma correspondência entre cada átomo de uma vizinhança com cada átomo da outra. Se considerarmos a distância entre cada par de átomos como a aresta de um poliedro (fig. 4.2.9), podemos comparar duas vizinhanças em função da similaridade entre as arestas correspondentes. 


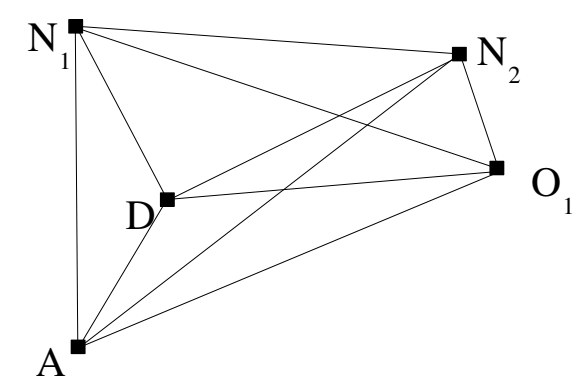

Figura 4.2.9 Conexão entre os átomos de uma vizinhança representando as distâncias e formando um poliedro.

Seja a lista de cada vizinhança $\mathrm{A}, \mathrm{D}, \mathrm{O}_{1}, \mathrm{O}_{2}, \ldots, \mathrm{O}_{\mathrm{m}}, \mathrm{N}_{1}, \mathrm{~N}_{2}, \ldots, \mathrm{N}_{\mathrm{n}}$. Podemos calcular a distância de cada combinação 2 a 2 destes átomos ignorando as combinações simétricas (a distância do ponto $\mathrm{A}$ ao ponto $\mathrm{B}$ é igual à distância do ponto $\mathrm{B}$ ao ponto $\mathrm{A}$ ):

$\mathrm{AD}$

$\mathrm{AO}_{1}, \mathrm{AO}_{2}, \ldots, \mathrm{AO}_{\mathrm{m}}$

$\mathrm{AN}_{1}, \mathrm{AN}_{2}, \ldots, \mathrm{AN}_{\mathrm{n}}$

$\mathrm{AO}_{1}, \mathrm{AO}_{2}, \ldots, \mathrm{AO}_{\mathrm{m}}$

$\mathrm{DN}_{1}, \mathrm{DN}_{2}, \ldots, \mathrm{DN}_{\mathrm{n}}$

$\mathrm{O}_{1} \mathrm{O}_{2}, \ldots, \mathrm{O}_{1} \mathrm{O}_{\mathrm{m}}, \mathrm{O}_{2} \mathrm{O}_{3}, \ldots, \mathrm{O}_{2} \mathrm{O}_{\mathrm{m}}, \ldots, \mathrm{O}_{\mathrm{m}-1} \mathrm{O}_{\mathrm{m}}$

$\mathrm{N}_{1} \mathrm{~N}_{2}, \ldots, \mathrm{N}_{1} \mathrm{~N}_{\mathrm{n}}, \mathrm{N}_{2} \mathrm{~N}_{3}, \ldots, \mathrm{N}_{2} \mathrm{~N}_{\mathrm{n}}, \ldots, \mathrm{N}_{\mathrm{n}-1} \mathrm{~N}_{\mathrm{n}}$

$\mathrm{O}_{1} \mathrm{~N}_{1}, . ., \mathrm{O}_{1} \mathrm{~N}_{\mathrm{n}}, \mathrm{O}_{2} \mathrm{~N}_{1}, . ., \mathrm{O}_{2} \mathrm{~N}_{\mathrm{n}}, \ldots, \mathrm{O}_{\mathrm{m}} \mathrm{N}_{1}, . ., \mathrm{O}_{\mathrm{m}} \mathrm{N}_{\mathrm{n}}$

Há um caso em que o uso da distância falha na diferenciação de dois objetos: quando eles apresentam simetria. Por exemplo, consideremos uma vizinhança deslocada/rotacionada de modo a ficar com o centro do orbital $C$ na origem dos eixos coordenados, o antecessor $A$ e o doador $D$ no eixo $y$ e o hidrogênio $H$ no eixo $z$. Podemos posicionar um receptor $R_{e}$ à esquerda do plano $y z$ como mostrado na figura 4.2.10. Se considerarmos a posição simétrica de $R_{e}$ ao plano $y z$ como sendo o ponto $R_{d}$, temos que as distâncias tanto de $R_{e}$ quanto de $R_{d}$ aos pontos $A, D, C$ e $H$ são iguais, por causa da simetria. Assim as vizinhanças contendo $R_{\mathrm{e}}$ e $R_{d}$, apesar de espacialmente diferentes quando sobrepostas, seriam consideradas iguais usando o critério de distância entre os átomos. 


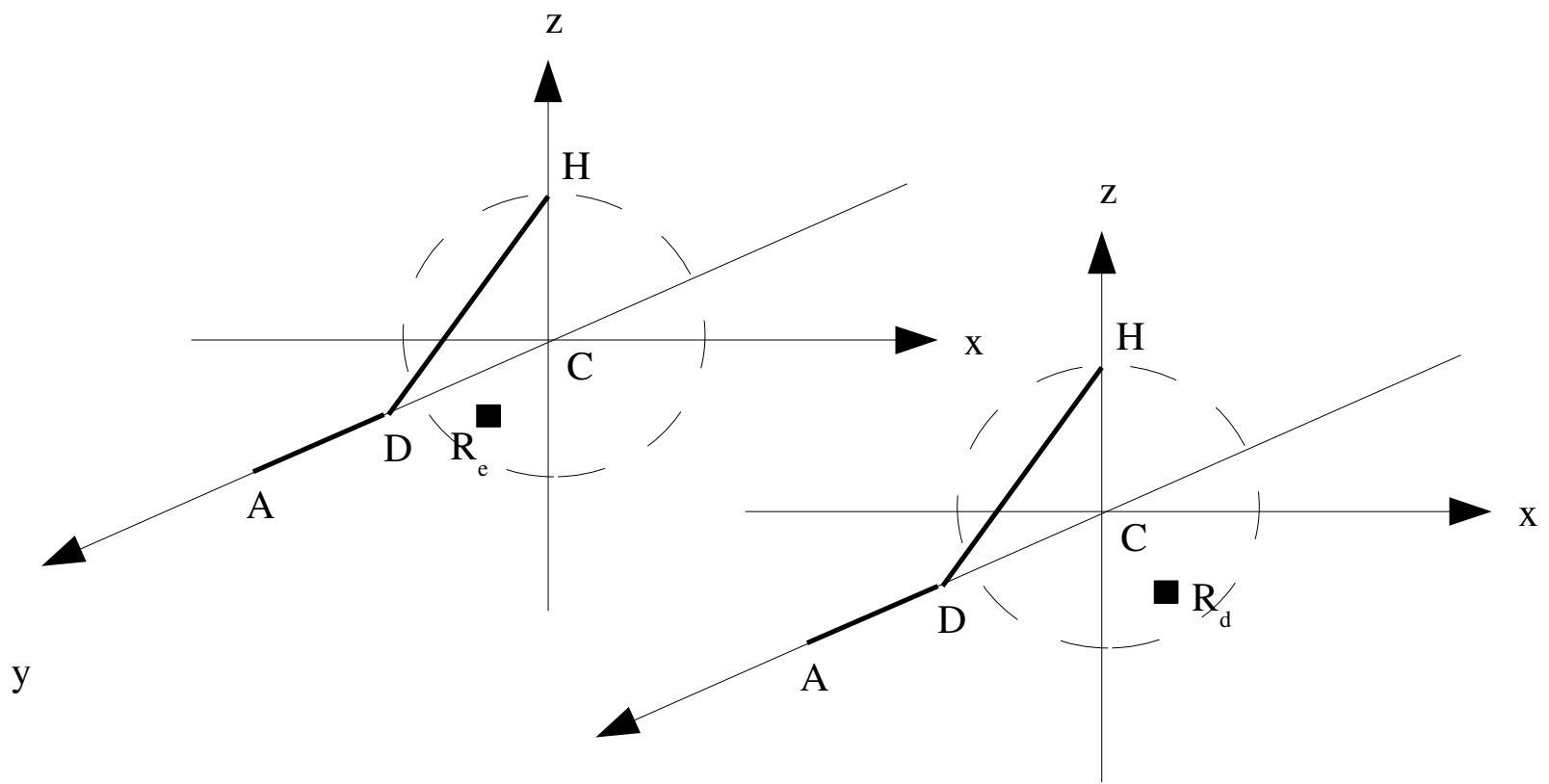

Figura 4.2.10 Duas vizinhanças simétricas com as mesmas distâncias do átomo receptor aos átomos antecessor, doador e hidrogênio.

Este problema pode ser evitado com introdução de um átomo âncora artificial em cada vizinhança não pertencente ao plano que contém o antecessor, o doador e o hidrogênio, por exemplo na interseção do orbital com o eixo x. Desta forma a distância do receptor ao ponto $A_{n}$ pode ser usada para diferenciar vizinhanças que apresentam a simetria mencionada.

\subsubsection{Agrupamento de vizinhanças com rede neural SOM}

O uso das distâncias entre os átomos de uma vizinhança, conforme visto na seção anterior, permite que vizinhanças possam ser comparadas independentemente da forma que estejam deslocadas/rotacionadas umas em relação às outras e fornece um critério que permite agrupá-las por similaridade. Considerando um conjunto inicial de vizinhanças com a mesma quantidade de receptores oxigênio $\mathrm{O}_{\mathrm{i}}$ e de receptores nitrogênio $\mathrm{N}_{\mathrm{j}}$, além do antecessor $A$, do doador $D$ e do hidrogênio $H$, para cada vizinhança podemos nomear os receptores e calcular listas de distâncias entre seus átomos. Imaginemos a concatenação destas listas de distâncias em um único vetor de comprimento $n$, um para cada vizinhança. Podemos usar estes vetores como padrões de entrada para uma rede auto-organizável (SOM, mapa de Kohonen), que então fará os agrupamentos dos vetores por similaridade.

Uma das formas mais simples de se usar o mapa de Kohonen é empregar-se uma grade de neurônios quadrada, isto é, uma matriz quadrada de largura $l$ contendo $l^{2}$ neurônios 
(células da matriz). Cada neurônio da grade também possui um vetor de pesos de comprimento $n$. Os padrões são apresentados iterativamente e um algoritmo de treinamento faz a atualização dos pesos dos neurônios até que um critério de parada seja atendido, geralmente quando as diferenças entre atualizações de duas iterações consecutivas tornamse muito pequenas, indicando uma convergência do método. Os pesos atribuídos ao vetor do neurônio são responsáveis pela atribuição de um grupo ao neurônio. Dado um padrão $P$ e o vetor de distâncias $\mathbf{V}_{\mathbf{P}}$ associado ao padrão, calcula-se a distância do vetor $\mathbf{V}_{\mathbf{P}}$ ao vetor de pesos de cada um dos neurônios, e o neurônio que apresentar a menor distância corresponde ao grupo em que o padrão será inserido.

O mapa de Kohonen pressupõe uma distribuição uniforme dos dados, porque durante o aprendizado, quando um padrão é apresentado à grade, os pesos do neurônio vencedor e de seus neurônios vizinhos são atualizados de modo a incorporarem parte da configuração dos pesos do padrão apresentado. Assim, se os dados de entrada tiverem distribuição irregular, os neurônios que forem vencedores com mais frequência dominarão suas vizinhanças, e os neurônios que tiverem poucos padrões associados serão descaracterizados.

\subsubsection{Agrupamento de vizinhanças por fusão de grupos}

Um novo algoritmo, denominado de agrupamento por fusão de grupos, foi desenvolvido para o agrupamento de vizinhanças. Considerando que não foi feita nenhuma análise estatística sobre os padrões de ligações hidrogênio obtidos da base PDB, não sabemos se os dados apresentam distribuição uniforme para serem adequadamente agrupados com o uso do mapa de Kohonen.

Em linhas gerais, o algoritmo utiliza-se de um conjunto de $n$ neurônios, cujo vetor de pesos é a média dos vetores dos padrões associados ao neurônio. É anotado para cada neurônio qual o outro neurônio mais próximo (em função da distância euclidiana do vetor de pesos, não da localização do neurônio na grade) e o valor da distância.

Cada vez que é apresentado um novo padrão é calculado o neurônio vencedor que tem o vetor de pesos mais próximo ao vetor de distâncias do padrão. Se esta distância do padrão ao neurônio vencedor for maior que a distância entre os 2 neurônios mais próximos, os vetores de peso dos 2 neurônios mais próximos são fundidos e armazenados em um dos dois neurônios e o outro neurônio passa a abrigar o novo padrão. Caso contrário, o vetor de distâncias do padrão é incorporado ao vetor de pesos do neurônio vencedor.

Após a apresentação de um padrão e incorporação de seus dados em algum neurônio, sempre é recalculada a distâncias entre os neurônios para atualizar-se a menor distância entre 2 neurônios antes da apresentação do próximo padrão. O processo é repetido até um 
número máximo de iterações, ou a ocorrência de uma iteração em que não haja fusão de neurônios indicando a convergência do algoritmo. Um pseudocódigo do algorimo é apresentado a seguir.

Algoritmo Fusão de Grupos

/* iniciação da grade de neurônios */

para i de 1 até $n$ faça

neuronios[i].somat $=0$;

neuronios $[i]$. media $=0$;

neuronios $[i] . q t d e=0$;

Obs: somat é vetor de pesos contendo o somatório dos vetores de distância dos padrões associados ao neurônio; qtde é a quantidade de padrões associados ao neurônio e media é o vetor contendo a divisão do vetor somat pela qtde.

/* iniciação da grade de neurônios com os primeiros $n$ padrões */

para i de 1 até $n$ faça

leia dados do i-ésimo padrão;

neuronios $[i]$. somat $=i$-ésimo_padrão.distâncias;

neuronios $[i]$. media $=i$-ésimo_padrão.distâncias;

neuronios $[i] . q t d e=1$;

/* executa primeira iteração */

CalculaNeuroniosMaisProximos(proximo1, proximo2, minDist);

para os j-ésimos padrões restantes faça

leia dados do j-ésimo padrão;

fusao $=0$

CalculaNeuronioMaisProximo(neuronioVencedor, dist);

se dist $>$ minDist

FundeCelulasMaisProximas( );

neuronioVencedor $=$ proximo 2 ;

fusao $=1$;

AdicionaPadrao(neuronioVencedor, j-ésimo_padrao);

RecalculaNeuroniosMaisProximos(proximo1, proximo2, minDist); 
Obs: CalculaNeuroniosMaisProximos(proximo1, proximo2, minDist) calcula para cada neurônio o neurônio mais próximo e a distância a este neurônio, minDist é a menor distância encontrada de quaisquer pares de neurônios e proximo1 e proximo2 são os índices no vetor neuronios do par de neurônios mais próximos; FundeCelulasMaisProximas( ) funde os dados dos neurônios proximo1 e proximo2 em proximo1 e deixa o neurônio proximo2 vazio; AdicionaPadrao incorpora os dados do j-ésimo padrão ao neuronioVencedor; RecalculaNeuroniosMaisProximos é uma versão otimizada de CalculaNeuroniosMaisProximos.

/* calcula demais iterações (épocas) enquanto houver fusao de celulas

eроса $=2 ;$ mudou $=1$;

enquanto (epoca $<=$ MAX_EPOCAS e mudou)

para todos os neuronios

zera somat

zera qtde

mudou $=0$;

para todos os padrões de entrada

leia dados do i-ésimo padrão;

fusao $=0$;

CalculaNeuronioMaisProximo(neuronioVencedor, dist);

se dist $>$ minDist

FundeCelulasMaisProximas( );

neuronioVencedor $=$ proximo2;

fusao $=1 ;$

AdicionaPadrao(neuronioVencedor, j-ésimo_padrao);

RecalculaNeuroniosMaisProximos(proximo1, proximo2, minDist);

se (fusao) $m$ mudou $=1$;

fim: para todos os padrões de entrada

incrementa epoca;

fim: enquanto (epoca $<=$ MAX_EPOCAS e mudou)

O procedimento RecalculaNeuroniosMaisProximos leva em consideração os neurônios que foram alterados para encontrar a menor distância entre dois neurônios sem 
ter que fazer uma busca exaustiva.

Após um padrão ser incorporado ao neurônio vencedor, os pesos do neurônio vencedor são alterados. Se houver uma fusão, os pesos dos neurônios proximo1 e proximo2 são fundidos em proximo1 e o padrão é incorporado em proximo2 que passa a ser o neurônio vencedor.

Inicialmente é calculada a nova distância mínima entre os neurônios que não sofreram alteração, para isto basta percorrer os neurônios não alterados e comparar a distância ao neurônio mais próximo já calculada e anotada no neurônio sendo percorrido. Não são percorridos os neurônios alterados (neurônio vencedor e possivelmente proximo1) e se o neurônio anotado como mais próximo do neurônio sendo percorrido for um neurônio alterado o par também é ignorado.

Para cada neurônio alterado, é recalculado o novo neurônio mais próximo, tendo-se que percorrer os demais neurônios e recalcular a distância do neurônio alterado ao neurônio percorrido. A seguir é descrito o que ocorre enquanto se percorre os demais neurônios. A distância entre o neurônio alterado e o neurônio percorrido é calculada e se for menor que a distância anotada do neurônio alterado, é anotado no neurônio alterado a distância e o neurônio percorrido como mais próximo. Se o neurônio alterado já era o neurônio anotado do novo neurônio escolhido como mais próximo do neurônio alterado, e a distância aumentou depois da alteração (o neurônio alterado afastou-se do neurônio escolhido como mais próximo), pode ser que exista outro neurônio mais próximo ao neurônio escolhido que não o neurônio alterado, e então o neurônio escolhido como mais próximo é anotado para posteriormente ter suas distâncias aos demais neurônios recalculadas e anotar-se o novo neurônio mais próximo a ele. Se a distância calculada do neurônio alterado ao neurônio sendo percorrido for menor que a distância anotada do neurônio sendo percorrido, a distância e o neurônio alterado são anotados no neurônio percorrido. Se a distância calculada do neurônio alterado ao neurônio percorrido for menor que a menor distância global entre dois neurônios, esta distância passa a ser a nova menor distância global entre dois neurônios, e proximo1 e proximo2 passam a ser o neurônio alterado e o neurônio percorrido.

\subsubsection{Fusão de grupos em duas fases}

Na seção anterior foi apresentada uma visão geral do algoritmo de fusão de grupos. Nesta seção vamos detalhar um pouco mais como este algoritmo foi realmente implementado para tratar o problema de agrupar as vizinhanças. O algoritmo é executado em duas fases: na primeira fase as vizinhanças são agrupadas em função da geometria dos 
átomos antecessor, doador e hidrogênio; na segunda fase cada grupo da primeira fase é usado como dado de entrada e particionado em novos grupos em função do agrupamento dos receptores da vizinhança. A justificativa para este procedimento segue a linha de obterse grupos de dados de entrada o mais similares possíveis para posteriormente alimentarem redes neurais especializadas nestes dados. Quando usamos todos os átomos disponíveis da vizinhança em uma única fase, a similaridade fica diluída em todos os parâmetros usados para o cálculo.

Inicialmente, todas as vizinhanças são deslocadas/rotacionadas para ficarem com a configuração para alinhamento simples (fig. 4.2.8) e é criado um átomo âncora na interseção do orbital do hidrogênio com o eixo $x$. Os neurônios contêm dois pares de vetores somat e media: um par para armazenar as coordenadas $\mathrm{x}, \mathrm{y}, \mathrm{z}$ dos átomos de interesse; outro par para armazenar as distâncias entre estes átomos. O vetor media das coordenadas apresenta para cada átomo da vizinhança no neurônio o valor médio das coordenadas dos átomos correspondentes dos padrões de entrada associados ao neurônio na iteração corrente. $\mathrm{O}$ vetor somat contém o somatório das coordenadas para o cálculo da média. Raciocínio análogo aplica-se aos vetores de distâncias. Desta forma fica subentendido que quando se usa um atributo do neurônio lidamos com valores médios, enquanto no padrão de entrada o atributo representa um valor único.

Na fase 1 , a distância entre dois neurônios $A$ e $B$ ou entre uma vizinhança $A$ e um neurônio $B$ é calculada como:

$$
\text { distância }=5|A \cdot D H-B \cdot D H|+3|A \cdot H C-B \cdot H C|+|A \cdot A D-B \cdot A D|
$$

onde

$|\mathrm{x}|$ representa o módulo (valor absoluto) de $\mathrm{x}$

$D H$ é a distância entre os átomos doador e hidrogênio

$H C$ é a distância entre o hidrogênio e o centro do orbital (esta distância é o raio do orbital)

$A D$ é a distância entre os átomos antecessor e doador.

Como podemos observar, esta fórmula para a distância prioriza o agrupamento de vizinhanças pelos comprimento da ligação $D H$, depois pelo raio do orbital e dá menos importância ao comprimento da ligação $A D$. A fase 1 permite obter grupos em que a 'parte fixa' da ligação hidrogênio, ou seja, o comprimento das ligações covalentes $A D, D H$ e do raio do orbital (e consequentemente o ângulo formado entre $A D H$ ), apresente uma similaridade muito grande, de forma estes valores posteriormente serão quase constantes 
quando usados como entrada para as redes neurais, coerentemente com o que é esperado dentro do domínio fisicoquímico do problema. Conforme já mencionado, os grupos produzidos na fase 1 são usados como dados de entrada para a fase 2.

A fase 2 busca a similaridade entre as posições dos átomos receptores da vizinhança, entre si e entre a 'parte fixa' da ligação hidrogênio. A 'parte fixa' na fase 2 é constituída pelos átomos $A, D, H$ além dos pontos $C$ (centro do orbital) e do ponto âncora $A_{n}$ (interseção do orbital com o eixo x), usado para diferenciar situações de simetria de receptores ao plano que contém os átomos $A, D, H$ (problema descrito na seção 4.2.3). Os receptores são duas listas de átomos: tipo oxigênio e tipo nitrogênio.

A distância entre neurônios $A$ e $B$ ou entre uma vizinhança $A$ e um neurônio $B$ é calculada como:

distância $=\sum\left|A \cdot x_{i}-B \cdot x_{i}\right|$

onde

$\mathrm{X}_{\mathrm{i}}$ representa um atributo de distância entre duas posições de uma vizinhança e as duas posições correspondentes da outra vizinhança considerada (padrão de entradaneurônio, neurônio-neurônio). A quantidade destes atributos depende do número de átomos receptores oxigênio $\mathrm{O}_{\mathrm{j}} \mathrm{s}$ e nitrogênio $\mathrm{N}_{\mathrm{k}} \mathrm{s}$. Estes atributos são as distâncias (podendo algumas não existerem se o número do oxigênios ou nitrogênios for zero):

- de cada $\mathrm{O}_{\mathrm{j}}$ e de cada $\mathrm{N}_{\mathrm{k}}$ aos pontos $\mathrm{A}, \mathrm{D}, \mathrm{H}$ e $\mathrm{A}_{\mathrm{n}}$ da 'parte fixa';

- de cada par de $\mathrm{O}_{\mathrm{j}} \mathrm{s}$ distintos, contado o par uma única vez (dados os pontos $X$ e $Y$, queremos contabilizar apenas a distância entre $X$ e $Y$, sem repetir a mesma distância dos pontos com a ordem trocada, isto é, entre $Y$ e $X$ );

- de cada par de $\mathrm{N}_{\mathrm{k}} \mathrm{S}$ distintos;

- de cada par $\left(\mathrm{O}_{\mathrm{j}}, \mathrm{N}_{\mathrm{k}}\right)$.

O termo 'duas posições correspondentes entre as vizinhanças consideradas' usado para definir $o$ atributo $x_{i}$ exige atenção especial na segunda fase. Implica que sempre que duas vizinhanças forem comparadas no algoritmo de fusão de grupos, antes será executado o algoritmo de nomeação por paridade de vizinhanças (seção 4.2.2.3) para a determinação da correspondência entre os receptores. Assim, um dado $\mathrm{Oj}$ da vizinhança $\mathrm{X}$ é provavelmente mapeado para um outro índice representando o oxigênio na vizinhança $Y$, após a nomeação por paridade. 


\subsubsection{Necessidade do alinhamento de padrões}

Um objeto rígido, quando movido, continua a ser o mesmo objeto e a conservar suas características. Entretanto, a percepção destas características em relação a pontos referenciais estáticos pode ser drasticamente alterada. Exemplos simples deste fato podem ser ilustrados com operações sobre imagens. Vamos considerar o número 6. Se fizermos uma rotação de 180 graus no sentido horário ou antihorário, o mesmo objeto é percebido como o número 9. Se fizermos um flip (simetria) em relação a um eixo horizontal fica parecido com a letra $e$. Se fizermos um flip em relação a um eixo vertical assemelha-se ao símbolo da derivação $\partial$ (fig. 4.2.11).
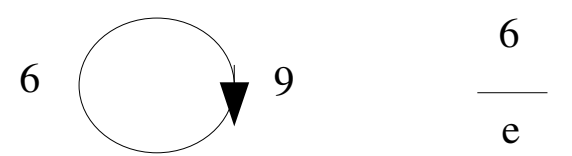

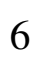

$\partial$

Figura 4.2.11 Alteração na percepção de imagem por movimentos.

Vamos escolher um padrão de ligação hidrogênio e consideremos uma translação do padrão, de modo que um de seus átomos coincida com a origem dos eixos coordenados, por exemplo o doador, e que este ponto permaneça fixo. Se fizermos todas as rotações com incremento de um grau em torno de cada um dos eixos coordenados, temos a imensa quantidade de $360^{3}=46.656 .000$ combinações. Em um arquivo de dados do PDB, cada um dos aminoácidos da proteína estará com uma disposição espacial próxima de apenas uma destas combinações. Além disto, obviamente ocupam posições distintas uns dos outros. $\mathrm{O}$ quanto estes fatos limitam a capacidade de aprendizado da rede neural? Para facilitar o aprendizado da rede optou-se por fazer uma superposição dos padrões, agrupados de forma que os dados fiquem 'quase' redundantes uns em relação aos outros. Como os padrões têm pequenas diferenças a superposição não é perfeita, de modo que os dados não são completamente redundantes. Teoricamente após o treinamento há quase um overfitting, e espera-se com isto conseguir maior precisão na previsão da posição do hidrogênio.

\subsubsection{Alinhamento inicial de vizinhanças por translação e rotações}

O agrupamento gera um conjunto de vizinhanças similares. O passo seguinte é superpor estas vizinhanças, para finalmente obter-se os dados de entrada para o treinamento da rede neural MLP que fará a previsão da posição dos hidrogênios.

O primeiro passo é escolher uma vizinhança para servir como referencial para a superposição das demais vizinhanças do agrupamento. São calculadas as distâncias médias entre cada par de átomos distintos da vizinhança e estas são copiadas para um vetor. A 
vizinhança escolhida como a referência é que apresentar o vetor de distâncias mais próximo do vetor das distâncias médias, através do uso de distância euclidiana aplicada aos vetores.

Um alinhamento inicial é feito individualmente sobre cada vizinhança através das seguintes movimentações ${ }^{6}$ :

- translação do átomo doador para a origem dos eixos coordenados;

- rotação de <doador $\rightarrow$ antecessor $>$ para coincidir com o eixo z: primeiro rotaciona-se $\mathrm{o}$ vetor em torno do eixo $\mathrm{x}$ até posicioná-lo no eixo xz e depois rotaciona-se o vetor em torno do eixo y parando no plano yz, como o vetor está nos planos xz e yz, necessariamente está na interseção destes planos, que é o eixo z;

- rotação do $<$ doador $\rightarrow$ primeiro receptor $>$ do padrão em torno do eixo z para coincidir com o vetor correspondente da vizinhança de referência.

\subsubsection{Ajuste do alinhamento de vizinhanças por AG}

Após a superposição inicial das vizinhanças à vizinhança de referência, conforme explicado na seção anterior, é feito um ajuste fino para sobrepor cada vizinhança (padrão) à referência, usando um algoritmo genético. Os indivíduos da população são compostos por triplas $\theta \mathrm{x}, \theta \mathrm{y}, \theta \mathrm{z}$ que representam ângulos de rotação (em graus) em torno dos eixos x,y e z (como já foi feito um alinhamento inicial, a rotação está sendo feita apenas em torno do eixo z). Uma população inicial de tamanho 50 é criada com repetições de 6 cromossomos tendo como genes rotações de +/- 1 grau, +/- 2 graus, +/- 3 graus em torno do eixo z (tabela 4.2.1), até se atingir a quantidade de 50 .

6 O movimento é descrito apenas para alguns átomos, mas considerando a vizinhança como um corpo rígido, fica implícito que a mesma operação também é executada para os demais átomos (e pontos âncora) não citados da vizinhança. 
Capítulo 4 Modelagem do problema

Tabela 4.2.1 Incrementos de rotação para criação de população inicial.

\begin{tabular}{|l|l|l|}
\hline$\theta x$ & $\theta y$ & $\theta z$ \\
\hline 0 & 0 & +1 \\
\hline 0 & 0 & -1 \\
\hline 0 & 0 & +2 \\
\hline 0 & 0 & -2 \\
\hline 0 & 0 & +3 \\
\hline 0 & 0 & -3 \\
\hline
\end{tabular}

Cada indivíduo (cromossomo) da população inicial é avaliado usando-se a seguinte função de aptidão: aplica-se consecutivamente as rotações indicadas nos genes do indivíduo em torno dos eixos correspondentes a partir da posição inicial do padrão; calcula-se o somatório das distâncias euclidianas entre cada átomo do padrão rotacionado e o átomo correspondente da vizinhança de referência.

Então é executado o algoritmo genético:

para $i=1$ até $i=1000$ faça

reproduz indivíduos

seleciona indivíduos mais aptos

escolhe melhor de todos os indivíduos

fim_para.

$\mathrm{Na}$ fase de reprodução dos indivíduos, primeiro são criados 50 clones iguais aos 50 pais, para manter-se os melhores resultados da geração anterior (pais) na seleção da nova geração. A partir do genótipo $\theta x, \theta y, \theta z$ do pai que representa a melhor avaliação (superposição à vizinhança referência), são criados 6 filhos do melhor pai com as variações $\theta \mathrm{x}, \theta \mathrm{y}, \theta \mathrm{z}$ da tabela 4.2.1 incrementadas aos genes $\theta \mathrm{x}, \theta \mathrm{y}, \theta \mathrm{z}$ do melhor pai, respectivamente. É criado um filho com uma mutação $\theta z \in$ Random (0,360). Outros 43 filhos são criados por crossover: sorteia-se aleatoriamente 2 dos 50 pais e gera-se dois filhos por crossover no ponto entre os genes $\theta \mathrm{y}$ e $\theta \mathrm{z}$. Como a modelagem atual prevê que somente $\theta \mathrm{z}$ é não nulo, na prática esta operação corresponde a replicar os dois pais. A modelagem inicial considerava valores não nulos para os 3 genes $\theta \mathrm{x}, \theta \mathrm{y}, \theta \mathrm{z}$, de forma que o operador crossover realmente geraria filhos com variação genética. A anulação de $\theta \mathrm{x}$ e $\theta \mathrm{y}$ foi posteriormente adotada para ter-se todos os padrões com o doador na origem dos eixos cartesianos, o vetor $<$ doador $\rightarrow$ antecessor $>$ coincidindo com o eixo $\mathrm{z}$ e apenas o hidrogênio e os receptores sofrendo 
incrementos rotacionais em torno do eixo $\mathrm{z}$.

Na fase de seleção inicialmente são escolhidos os 2 pais que representam as 2 melhores soluções, os outros pais são eliminados. Então 48 filhos são selecionados por torneio e promovidos a pais. Na seleção por torneio 3 filhos são sorteados, e dentre estes 3 filhos o que tiver melhor valor da função de aptidão é selecionado para se transformar em um novo pai. Como o sorteio é aleatório, qualquer filho pode participar de mais de um torneio, se for sorteado várias vezes. Então os 100 filhos são eliminados, ficando os novos 50 pais.

Ao fim da execução do algoritmo genético, as rotações do melhor indivíduo (com a melhor avaliação da função de aptidão) são aplicadas ao conjunto de átomos do padrão.

\subsection{Treinamento da rede neural}

O modelo de rede neural escolhido para fazer a previsão da posição do átomo de hidrogênio foi o modelo MLP. A entrada dos dados consiste das coordenadas x,y,z dos átomos antecessor, doador, receptores oxigênio (se houver) e receptores nitrogênio (se houver). Então existem uma ou duas camadas intermediárias de neurônios e a camada de saída com 3 neurônios, um para cada coordenada $\mathrm{x}, \mathrm{y}$ e $\mathrm{z}$ do átomo de hidrogênio.

Foram definidos dois grupos de parâmetros: o grupo mais antigo (por histórico das implementações) consiste em parâmetros que precisam ser alterados no próprio códigofonte, outro grupo é editado em um arquivo texto (chamado de arquivo de configuração) que é lido durante a execução do programa já compilado e atribui os parâmetros às variáveis correspondentes do programa em tempo de execução.

Os parâmetros contidos no código-fonte são:

- porcentagem dos padrões que devem ser usados para formar os conjuntos de treino, validação e teste (devem totalizar 100\%);

- $\quad$ arquivos de configuração, de entrada de dados e de saída;

- constantes das funções de limiar sigmóide e tangente hiperbólica.

Os parâmetros do arquivo de configuração são:

- número de neurônios da camada de entrada (( 1 antecessor +1 doador $+n$ oxigênios $+\mathrm{m}$ nitrogênios) $* 3$, onde 3 é número das coordenadas $\mathrm{x}, \mathrm{y}, \mathrm{z})$;

- número de neurônios da primeira camada intermediária;

- número de neurônios da segunda camada intermediária; 
- número de neurônios da camada de saída (sempre 3: x,y,z do hidrogênio);

- função de ativação: sigmóide ou tangente hiperbólica;

- método de atualização dos pesos: sequencial (on line) ou batch;

- número máximo de épocas de treinamento;

- uso do termo momento para atualização dos pesos: sim/não;

- valor inicial da taxa de aprendizado;

- valor de decréscimo da taxa de aprendizado por época;

- magnitude para atribuição inicial dos pesos das conexões da rede;

- erro quadrático mínimo: se alguma época do treinamento atingir este valor o treinamento é encerrado.

Após os dados de entrada serem lidos, são deslocados de forma que todas as coordenadas fiquem positivas, e que o menor valor das coordenadas em qualquer direção seja posicionado com uma folga de $10 \%$ do valor máximo - mínimo, a partir da origem. Os dados são comprimidos proporcionalmente de forma que fiquem no intervalo $(0,1)$ em cada coordenada (porque este é o intervalo de saída da função de ativação sigmóide, atualmente usada nos experimentos), e um fator de expansão é calculado para permitir a expansão dos valores comprimidos para os valores originais.

A distância média dos átomos doador-hidrogênio e centro do orbital-hidrogênio dos padrões de entrada são calculadas para permitir que além da posição do hidrogênio prevista diretamente pela rede neural, uma posição normalizada possa ser calculada a partir da posição prevista usando estes comprimentos médios.

A partir dos parâmetros de configuração da arquitetura da rede, é criada dinamicamente a estrutura da rede neural, e a rede é treinada com os dados de treino usando o algoritmo backpropagation.

Ao término de cada época, é calculado para cada padrão de validação a posição do hidrogênio prevista pela rede. Então é calculado o erro (distância simples) entre as posições desejada e prevista expandidas para o tamanho original, usando-se o fator de expansão. São calculados a quantidade de resultados ótimos nroOtimo(erro $\leqslant 0,2 \AA$ ), a quantidade de resultados bons nroBons $(0,2 \AA<$ erro $\leqslant 0,6 \AA$ ) e a quantidade de resultados ruins nroRuins ( erro > 0,6 ). Uma pontuação para a generalização dos dados de validação na época corrente é calculada pela soma ponderada $1,5 *$ nroOtimo + nroBom. Cada vez que a pontuação da época corrente ultrapassa a pontuação da melhor época já vista, a pontuação 
da época corrente passa a ser a pontuação da melhor época já vista, e é criada uma cópia da arquitetura atual e parâmetros da época corrente, que corresponde à melhor configuração da rede para os dados de validação.

Após o término do treinamento, é criado um arquivo de saída com estatísticas (erro quadrático médio, quantidade e porcentagem de resultados ótimos, bons e ruins) sobre os dados de treinamento diretamente calculados pela rede e sobre estes dados normalizados com o comprimento médio da ligação doador-hidrogênio, usando a configuração final atingida pela rede após o fim do treinamento. As mesmas estatísticas são apresentadas para os dados de validação e teste, mas se usando a melhor configuração da rede para os dados de validação. 
Capítulo 4 Modelagem do problema 


\section{Capítulo 5 Experimentos}

Este capítulo apresenta os resultados do treinamento de redes neurais MLP para a previsão da posição do átomo hidrogênio contido em grupos hidroxila $(\mathrm{OH}-)$ da cadeia lateral dos aminoácidos serina, treonina e tirosina em proteínas. A intenção não é detalhar todos os experimentos realizados, mas mostrar como mudanças na modelagem do problema conduziram a uma evolução nos resultados obtidos. Inicialmente foi usado o método de nomeação de por projeção escalar para identificar os receptores das vizinhanças e o modelo de rede neural SOM para o agrupamento das vizinhanças para gerar os grupos de entrada de padrões para alimentar as redes neurais modelo MLP para fazer a predição da posição do átomo de hidrogênio. Como os resultados obtidos dos experimentos com estes métodos foram muito ruins, foi preciso repensar a metodologia, principalmente a parte de préprocessamento dos dados. Em consequência foram desenvolvidos os novos métodos de nomeação por paridadade de vizinhança para estabelecer a correspondência entre átomos receptores pertencentes a duas vizinhanças sendo comparadas e um novo algoritmo de agrupamento, o algoritmo de fusão de grupos. Com o uso destes novos métodos os experimentos apresentaram resultados muito melhores.

A configuração vizinhança esférica, nomeação de receptores por projeção escalar, agrupamento de dados com o uso de mapa de Kohonen e superposição de padrões com o uso de algoritmos genéticos, foi executada para obter-se os dados de entrada da rede MLP. Então alguns experimentos iniciais foram conduzidos para direcionar a escolha dos parâmetros da rede MLP.

Quanto à função de ativação, a função sigmóide apresentou um treinamento adequado, reduzindo suave e progressivamente o erro quadrático, enquanto a funcão tangente hiperbólica apresentou problemas, com valores produzidos frequentemente caindo na faixa de saturação da função, onde a derivada não apresenta variações significativas e em consequência o processo de treinamento da rede fica paralisado, porque a atualização dos pesos das conexões ao longo da rede torna-se insignificante, ou então fica instável. O erro quadrático apresentou oscilações de aumento e diminuição durante o treinamento. Também experimentou-se alterar os parâmetros das funções sigmóide e tangente hiperbólica de forma a expandir o intervalo do conjunto-imagem destas funções para abranger os dados das coordenadas da posição do átomo de hidrogênio sem a necessidade de serem reescalados, mas não houve convergência do treinamento alterando estes parâmetros. Nestes primeiros experimentos eram realizados 100.000 épocas para o treinamento da rede neural, e cada experimento demorava em média de duas a quatro horas de execução, dependendo do tamanho da arquitetura da rede utilizada. 
Com relação à capacidade de aproximação da função, experimentou-se usar uma rede com 3 neurônios de saída correspondentes às coordenadas $\mathrm{x}, \mathrm{y}, \mathrm{z}$ treinada uma única vez, e 3 redes com apenas um neurônio de saída, cada rede representando uma única coordenada. Os resultados foram equivalentes e assim é computacionalmente mais eficiente treinar-se uma única rede com 3 neurônios de saída, do que fazer-se o treinamento de 3 redes independentes.

Outro experimento realizado foi utilizar os valores dos 3 cossenos diretores do vetor formado pelo átomo doador e pelo átomo hidrogênio no lugar das coordenadas x,y,z e os resultados foram aproximadamente equivalentes.

Estes experimentos iniciais direcionaram a seguinte configuração para uso da rede MLP em experimentos futuros: uso da função de ativação sigmóide com parâmetros padrão, reescalamento dos dados de entrada dos padrões para ficarem dentro do intervalo $(0,1)$ da função sigmóide e uso direto das coordenadas $\mathrm{x}, \mathrm{y}, \mathrm{z}$ para os neurônios da camada de saída da rede. A partir deste direcionamento inicial, vários experimentos foram realizados. Nas seções seguintes são apresentados os experimentos com as diferentes configurações associadas aos mesmos.

\subsection{Vizinhança esférica}

Por razões de simplicidade de implementação, usou-se inicialmente a configuração: vizinhança esférica com raio de 3,5 $\AA$ centrada no átomo doador, nomeação de receptores por projeção escalar, agrupamento de dados com o uso de mapa de Kohonen usando-se uma grade quadrada de tamanho 10 e superposição de padrões com o uso de algoritmos genéticos, para obter-se os dados de entrada da rede MLP.

Um total de 39 experimentos foi realizado usando-se como entrada grupos contendo diferentes quantidades de receptores: apenas um oxigênio; apenas um nitrogênio; um oxigênio e um nitrogênio; dois oxigênios e dois nitrogênios; três oxigênios e três nitrogênios. Para cada arquivo de entrada contendo um grupo, foram realizados experimentos diferenciados: pelas porcentagens do total de padrões contidos no grupo para servirem como dados de treino, validação e teste, mostradas na tabela 5.1 .1 e pela arquitetura da rede MLP (quantidade de neurônios na primeira e segunda camadas intermediárias, camada de saída) mostrada na tabela 5.1.2. 
Tabela 5.1.1 Porcentagem de padrões para treinamento da rede neural.

\begin{tabular}{|l|l|l|}
\hline Treino (\%) & Validação (\%) & Teste (\%) \\
\hline 80 & 10 & 10 \\
\hline 50 & 25 & 25 \\
\hline
\end{tabular}

Tabela 5.1.2 Arquiteturas de rede MLP usadas nos experimentos

\begin{tabular}{|l|l|l|}
\hline $\begin{array}{c}\boldsymbol{1}^{\boldsymbol{a}} \text { camada } \\
\text { intermediária }\end{array}$ & $\begin{array}{c}\boldsymbol{2}^{\boldsymbol{a}} \text { camada } \\
\text { intermediária }\end{array}$ & $\begin{array}{c}\text { Camada } \\
\text { de saída }\end{array}$ \\
\hline 12 & 12 & 3 \\
\hline 24 & 24 & 3 \\
\hline 48 & 12 & 3 \\
\hline 48 & 24 & 3 \\
\hline
\end{tabular}

Os experimentos possuem em comum a definição dos valores de alguns parâmetros, conforme mostrado na tabela 5.1.3.

Em cada experimento, é calculado o comprimento médio da ligação doadorhidrogênio usando-se todos os padrões de entrada do grupo (treino, validação e teste) que apresentam um valor próximo de $0,96 \AA$, com pequenas diferenças de experimento para experimento. A partir das coordenadas $\mathrm{x}_{\mathrm{p}}, \mathrm{y}_{\mathrm{p}}, \mathrm{z}_{\mathrm{p}}$ do átomo de hidrogênio produzidas (calculadas) pela rede, cria-se um vetor com a mesma direção e sentido que o vetor com origem na posição do átomo doador e fim na posição do hidrogênio, com o comprimento médio da ligação doador-hidrogênio e origem no doador. O fim deste vetor é a posição normalizada (pelo comprimento médio da ligação) do átomo de hidrogênio com coordenadas $\mathrm{x}_{\mathrm{n}}, \mathrm{y}_{\mathrm{n}}, \mathrm{Z}_{\mathrm{n}}$. A posição correta (desejada) do átomo de hidrogênio tal como aparece no padrão de entrada é dada pelas coordenadas $\mathrm{x}_{\mathrm{d}}, \mathrm{y}_{\mathrm{d}}, \mathrm{Z}_{\mathrm{d}}$. $\mathrm{O}$ erro quadrático EQ de um dado padrão $i$ é calculado como:

$$
\mathrm{EQ}(\mathrm{i})=\frac{1}{2} \sqrt{\left(x_{d}-x_{p}\right)^{2}+\left(y_{d}-y_{p}\right)^{2}+\left(z_{d}-z_{p}\right)^{2}}
$$

O erro quadrático médio de um conjunto de $N$ padrões é dado por: 
Capítulo 5 Experimentos

$$
\mathrm{EQ}_{\mathrm{m}}=\frac{1}{N} \sum_{i=1}^{N} E Q(i)
$$

Analogamente, podemos calcular o erro padrão EQN(i) para a posição prevista normalizada do átomo de hidrogênio do padrão i como:

$$
\operatorname{EQN}(\mathrm{i})=\frac{1}{2} \sqrt{\left(x_{d}-x_{n}\right)^{2}+\left(y_{d}-y_{n}\right)^{2}+\left(z_{d}-z_{n}\right)^{2}}
$$

O erro quadrático médio de um conjunto de $\mathrm{N}$ padrões normalizados é dado por:

$$
\mathrm{EQN}_{\mathrm{m}}=\frac{1}{N} \sum_{i=1}^{N} E Q N(i)
$$

Tabela 5.1.3 Parâmetros de configuração comuns aos experimentos

\begin{tabular}{|l|l|}
\hline \multicolumn{1}{|c|}{ Parâmetro } & \multicolumn{1}{c|}{ Descrição } \\
\hline função de ativação & Função sigmóide, definida por: $1 /\left(1+\mathrm{e}^{-\mathrm{x}}\right)$ \\
\hline$\eta$ & $\begin{array}{l}\text { Taxa de aprendizado, utilizada para a atualização dos pesos das conexões } \\
\text { da rede MLP } \text {. O valor inicial da taxa é 0.1 e após cada iteração (época) } \\
\text { do treinamento é reduzido, multiplicando-se o valor atual por } 0.999\end{array}$ \\
\hline$\alpha$ & $\begin{array}{l}\text { Termo momento } \\
\text { por: Seu valor é calculado em cada iteração do treinamento } \alpha-\eta\end{array}$ \\
\hline Fator peso & $\begin{array}{l}\text { Parâmetro com valor } 0,05 \text { utilizado na atribuição inicial dos pesos } \mathrm{w}_{\mathrm{ij}} \text { das } \\
\text { conexões entre neurônios da rede MLP. } \\
\mathrm{W}_{\mathrm{ij}}=\text { Rand(-10,10)*fator_peso, onde Rand(com,fim) gera aleatoriamente } \\
\text { um inteiro no intervalo [com,fim] }\end{array}$ \\
\hline Épocas & Número de épocas (iterações) para o treinamento da rede. Valor $=10000$. \\
\hline
\end{tabular}

7 Definido na eq. (3.24) da seção 3.3.3.1

8 Definido na eq. (3.28) da seção 3.3.3.2 
Um resultado (previsão da posição do átomo de hidrogênio) é determinado como ótimo, bom ou ruim seguindo-se a classificação proposta por L. Forrest e B. Honig para a avalição dos procedimentos existentes [Forrest \& Honig, 2005]. A distância entre a posição prevista pelo método e a posição correta do átomo de hidrogênio é calculada e então classificada em intervalos de distância em Å. Considerando que o erro quadrático é metade da distância ao quadrado como visto nas eq. (5.1) e (5.3), podemos representar estes intervalos de distância também em função do erro quadrático, como mostrado na tabela 5.1.4.

Tabela 5.1.4 Classificacão de resultados dos experimentos

\begin{tabular}{|l|l|l|}
\hline Resultado & Intervalo de distância & \multicolumn{1}{|c|}{ Intervalo de erro quad. } \\
\hline ótimo & $0,0<$ dist $<=0,2$ & $0,00<=$ erro quad $<=0,1$ \\
\hline bom & $0,2<$ dist $<=0,6$ & $0,1<$ erro quad $<=0,3$ \\
\hline ruim & $0,6<$ dist & $0,3<$ erro quad \\
\hline
\end{tabular}

Dado um conjunto de $n$ padrões, com quantidades nro $_{\text {ot }}$ de resultados ótimos, nro $_{\text {bom }}$ de resultados bons e nro $_{\text {ruim }}$ de resultados ruins, uma pontuação empírica ${ }^{9}$ para este conjunto de resultados é dada por:

$$
\text { pontuação(n) }=1,5 \mathrm{nro}_{\text {ot }}+1,0 \mathrm{nro}_{\text {bom }}
$$

Durante o processo de treinamento, após cada época é feita a pontuação dos dados de validação usando a eq. (5.5). A época que apresentar a maior pontuação é denominada de melhor época de validação e são anotados o número da época e os pesos das conexões da rede (parâmetros livres). Em cada experimento, os dados de treino são classificados e pontuados usando-se os pesos das conexões da rede atualizados após o número máximo de épocas de treinamento (parâmetro Épocas da tabela 5.1.3). Os dados de validação e teste são classificados e pontuados usando-se os pesos anotados na melhor época de validação.

Os resultados de experimentos com um grupo contendo um átomo receptor oxigênio, com $80 \%$ dos dados para treino, $10 \%$ para validação e $10 \%$ de teste, dados produzidos pela rede e dados normalizados, são mostrados nas tabelas: 5.1.5, e 5.1.6 para a arquitetura ${ }^{10} 12 \mathrm{X} 12$, 5.1 .7 e 5.1 .8 para a arquitetura $24 \mathrm{X} 24,5.1 .9$ e 5.1 .10 para a arquitetura $48 \mathrm{X} 12,5.1 .11$ e 5.1 .12 para a arquitetura 48X24.

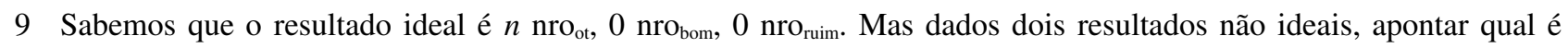
melhor que o outro muitas vezes é uma tarefa subjetiva.

10 Quantidade de neurônios da primeira camada intermediária X quantidade de neurônios da segunda camada intermediária. 
Capítulo 5 Experimentos

Tabela 5.1.5 Experimento com vizinhança esférica, um receptor oxigênio, arquitetura 12X12, não normalizado.

\begin{tabular}{|c|c|c|}
\hline \multicolumn{3}{|c|}{ Arquitetura } \\
\hline $\begin{array}{l}1^{a} \text { camada } \\
\text { intermediária }\end{array}$ & $\begin{array}{l}2^{a} \text { camada } \\
\text { intermediária }\end{array}$ & $\begin{array}{l}\text { Camada } \\
\text { de saída }\end{array}$ \\
\hline 12 & 12 & 3 \\
\hline \multicolumn{3}{|c|}{ Divisão de dados } \\
\hline Treino $(\%)$ & Validação (\%) & Teste $(\%)$ \\
\hline 80 & 10 & 10 \\
\hline \multicolumn{3}{|c|}{ DADOS DE TREINAMENTO } \\
\hline Resultado & $\%$ de padrões & Quantidade de padrões \\
\hline ótimo & 0,1 & 2 \\
\hline bom & 2,7 & 90 \\
\hline ruim & 97,3 & 3291 \\
\hline erro quad. médio & \multicolumn{2}{|l|}{0,3916} \\
\hline pontuação & \multicolumn{2}{|l|}{92} \\
\hline \multicolumn{3}{|c|}{ DADOS DE VALIDAÇÃO } \\
\hline Melhor época de validação & \multicolumn{2}{|l|}{4222} \\
\hline Resultado & \% de padrões & Quantidade de padrões \\
\hline ótimo & 0 & 0 \\
\hline bom & 0 & 0 \\
\hline ruim & 100 & 422 \\
\hline erro quad. médio & \multicolumn{2}{|l|}{0,4075} \\
\hline pontuação & \multicolumn{2}{|l|}{0} \\
\hline \multicolumn{3}{|c|}{ DADOS DE TESTE } \\
\hline Resultado & \% de padrões & Quantidade de padrões \\
\hline ótimo & 0 & 0 \\
\hline bom & 0,2 & 1 \\
\hline ruim & 99,8 & 423 \\
\hline erro quad. médio & \multicolumn{2}{|l|}{0,3997} \\
\hline pontuação & \multicolumn{2}{|l|}{1} \\
\hline
\end{tabular}


Tabela 5.1.6 Experimento com vizinhança esférica, um receptor oxigênio, arquitetura 12X12, normalizado.

\begin{tabular}{|c|c|c|}
\hline \multicolumn{3}{|c|}{ Arquitetura } \\
\hline $\begin{array}{l}1^{a} \text { camada } \\
\text { intermediária }\end{array}$ & $\begin{array}{l}2^{a} \text { camada } \\
\text { intermediária }\end{array}$ & $\begin{array}{l}\text { Camada } \\
\text { de saída }\end{array}$ \\
\hline 12 & 12 & 3 \\
\hline \multicolumn{3}{|c|}{ Divisão de dados } \\
\hline Treino (\%) & Validação (\%) & Teste $(\%)$ \\
\hline 80 & 10 & 10 \\
\hline \multicolumn{3}{|c|}{ DADOS DE TREINAMENTO } \\
\hline Resultado & $\%$ de padrões & Quantidade de padrões \\
\hline ótimo & 9,1 & 308 \\
\hline bom & 21,3 & 719 \\
\hline ruim & 69,6 & 2356 \\
\hline erro quad. médio & \multicolumn{2}{|l|}{0,6646} \\
\hline pontuação & \multicolumn{2}{|l|}{1181} \\
\hline \multicolumn{3}{|c|}{ DADOS DE VALIDAÇÃO } \\
\hline Melhor época de validação & \multicolumn{2}{|l|}{4222} \\
\hline Resultado & $\begin{array}{l}\text { \% de padrões } \\
\text { do grupo }\end{array}$ & Quantidade de padrões \\
\hline ótimo & 10 & 42 \\
\hline bom & 17,5 & 74 \\
\hline ruim & 72,5 & 306 \\
\hline erro quad. médio & \multicolumn{2}{|l|}{0,7229} \\
\hline pontuação & \multicolumn{2}{|l|}{137} \\
\hline \multicolumn{3}{|c|}{ DADOS DE TESTE } \\
\hline Resultado & $\%$ de padrões & Quantidade de padrões \\
\hline ótimo & 10,8 & 46 \\
\hline bom & 19,8 & 84 \\
\hline ruim & 69,3 & 294 \\
\hline erro quad. médio & \multicolumn{2}{|l|}{0,6896} \\
\hline pontuação & \multicolumn{2}{|l|}{153} \\
\hline
\end{tabular}

Podemos observar um fato interessante na tabela 5.1.5: apesar dos dados não normalizados apresentarem um erro quadrático médio menor, os resultados são visivelmente piores quando consideramos as faixas ótimo, bom, ruim e a pontuação, em comparação com os dados não normalizados. Este fato demonstra a importância da função de pontuação para selecionar a melhor 


\section{Capítulo 5 Experimentos}

época de validação para o problema tratado, ao invés do uso do erro quadrático médio, que é o critério recomendado pela maioria dos autores. Podemos ver claramente na tabela, que a causa desta distorção é que nos nos dados não normalizados há maior quantidade de resultados ruins com erro menor baixando a média, ao passo que nos dados normalizados há menor quantidade de resultados ruins mas com erro maior elevando a média do erro quadrático. 
Capítulo 5 Experimentos

Tabela 5.1.7 Experimento com vizinhança esférica, um receptor oxigênio, arquitetura $24 X 24$, não normalizado.

\begin{tabular}{|c|c|c|}
\hline \multicolumn{3}{|c|}{ Arquitetura } \\
\hline $\begin{array}{l}1^{\text {a }} \text { camada } \\
\text { intermediária }\end{array}$ & $\begin{array}{l}2^{\mathrm{a}} \text { camada } \\
\text { intermediária }\end{array}$ & $\begin{array}{l}\text { Camada } \\
\text { de saída }\end{array}$ \\
\hline 24 & 24 & 3 \\
\hline \multicolumn{3}{|c|}{ Divisão de dados } \\
\hline Treino $(\%)$ & Validação (\%) & Teste (\%) \\
\hline 80 & 10 & 10 \\
\hline \multicolumn{3}{|c|}{ DADOS DE TREINAMENTO } \\
\hline Resultado & $\begin{array}{l}\text { \% do total de padrões } \\
\text { do grupo }\end{array}$ & Quantidade de padrões \\
\hline ótimo & 0 & 0 \\
\hline bom & 2,9 & 99 \\
\hline ruim & 97,1 & 3284 \\
\hline erro quad. médio & \multicolumn{2}{|l|}{0,3912} \\
\hline pontuação & \multicolumn{2}{|l|}{99} \\
\hline \multicolumn{3}{|c|}{ DADOS DE VALIDAÇÃO } \\
\hline Melhor época de validação & \multicolumn{2}{|l|}{4256} \\
\hline Resultado & $\begin{array}{l}\text { \% do total de padrões } \\
\text { do grupo }\end{array}$ & Quantidade de padrões \\
\hline ótimo & 0 & 0 \\
\hline bom & 0,2 & 1 \\
\hline ruim & 99,8 & 421 \\
\hline erro quad. médio & \multicolumn{2}{|l|}{0,4074} \\
\hline pontuação & \multicolumn{2}{|l|}{1} \\
\hline \multicolumn{3}{|c|}{ DADOS DE TESTE } \\
\hline Resultado & $\begin{array}{l}\text { \% do total de padrões } \\
\text { do grupo }\end{array}$ & Quantidade de padrões \\
\hline ótimo & 0 & 0 \\
\hline bom & 0,2 & 1 \\
\hline ruim & 99,8 & 423 \\
\hline erro quad. médio & \multicolumn{2}{|l|}{0,4021} \\
\hline pontuação & \multicolumn{2}{|l|}{1} \\
\hline
\end{tabular}


Tabela 5.1.8 Experimento com vizinhança esférica, um receptor oxigênio, arquitetura $24 X 24$, normalizado.

\begin{tabular}{|c|c|c|}
\hline \multicolumn{3}{|c|}{ Arquitetura } \\
\hline $\begin{array}{l}\mathbf{1}^{\text {a }} \text { camada } \\
\text { intermediária }\end{array}$ & $\begin{array}{l}2^{\text {a }} \text { camada } \\
\text { intermediária }\end{array}$ & $\begin{array}{l}\text { Camada } \\
\text { de saída }\end{array}$ \\
\hline 24 & 24 & 3 \\
\hline \multicolumn{3}{|c|}{ Divisão de dados } \\
\hline Treino $(\%)$ & Validação (\%) & Teste $(\%)$ \\
\hline 80 & 10 & 10 \\
\hline \multicolumn{3}{|c|}{ DADOS DE TREINAMENTO } \\
\hline Resultado & $\begin{array}{l}\text { \% do total de padrões } \\
\text { do grupo }\end{array}$ & Quantidade de padrões \\
\hline ótimo & 10 & 337 \\
\hline bom & 19,1 & 645 \\
\hline ruim & 71 & 2401 \\
\hline erro quad. médio & \multicolumn{2}{|l|}{0,6608} \\
\hline pontuação & \multicolumn{2}{|l|}{1150} \\
\hline \multicolumn{3}{|c|}{ DADOS DE VALIDAÇÃO } \\
\hline Melhor época de validação & \multicolumn{2}{|l|}{4256} \\
\hline Resultado & $\begin{array}{l}\text { \% do total de padrões } \\
\text { do grupo }\end{array}$ & Quantidade de padrões \\
\hline ótimo & 10,2 & 43 \\
\hline bom & 18,5 & 78 \\
\hline ruim & 71,3 & 301 \\
\hline erro quad. médio & \multicolumn{2}{|l|}{0,7183} \\
\hline pontuação & \multicolumn{2}{|l|}{142} \\
\hline \multicolumn{3}{|c|}{ DADOS DE TESTE } \\
\hline Resultado & $\begin{array}{l}\text { \% do total de padrões } \\
\text { do grupo }\end{array}$ & Quantidade de padrões \\
\hline ótimo & 10,6 & 45 \\
\hline bom & 19,8 & 84 \\
\hline ruim & 69,6 & 295 \\
\hline erro quad. médio & \multicolumn{2}{|l|}{0,6994} \\
\hline pontuação & \multicolumn{2}{|l|}{151} \\
\hline
\end{tabular}


Capítulo 5 Experimentos

Tabela 5.1.9 Experimento com vizinhança esférica, um receptor oxigênio, arquitetura 48X12, não normalizado.

\begin{tabular}{|c|c|c|}
\hline \multicolumn{3}{|c|}{ Arquitetura } \\
\hline $\begin{array}{l}\mathbf{1}^{\text {a }} \text { camada } \\
\text { intermediária }\end{array}$ & $\begin{array}{l}2^{\text {a }} \text { camada } \\
\text { intermediária }\end{array}$ & $\begin{array}{l}\text { Camada } \\
\text { de saída }\end{array}$ \\
\hline 24 & 24 & 3 \\
\hline \multicolumn{3}{|c|}{ Divisão de dados } \\
\hline Treino $(\%)$ & Validação (\%) & Teste $(\%)$ \\
\hline 80 & 10 & 10 \\
\hline \multicolumn{3}{|c|}{ DADOS DE TREINAMENTO } \\
\hline Resultado & $\begin{array}{l}\text { \% do total de padrões } \\
\text { do grupo }\end{array}$ & Quantidade de padrões \\
\hline ótimo & 0.1 & 3 \\
\hline bom & 2.9 & 98 \\
\hline ruim & 97 & 3282 \\
\hline erro quad. médio & \multicolumn{2}{|l|}{0,3906} \\
\hline pontuação & \multicolumn{2}{|l|}{101} \\
\hline \multicolumn{3}{|c|}{ DADOS DE VALIDAÇÃO } \\
\hline Melhor época de validação & \multicolumn{2}{|l|}{4256} \\
\hline Resultado & $\begin{array}{l}\text { \% do total de padrões } \\
\text { do grupo }\end{array}$ & Quantidade de padrões \\
\hline ótimo & 0 & 0 \\
\hline bom & 0,2 & 1 \\
\hline ruim & 99,8 & 421 \\
\hline erro quad. médio & \multicolumn{2}{|l|}{0,4057} \\
\hline pontuação & \multicolumn{2}{|l|}{142} \\
\hline \multicolumn{3}{|c|}{ DADOS DE TESTE } \\
\hline Resultado & $\begin{array}{l}\text { \% do total de padrões } \\
\text { do grupo }\end{array}$ & Quantidade de padrões \\
\hline ótimo & 0 & 0 \\
\hline bom & 0.5 & 2 \\
\hline ruim & 99,5 & 422 \\
\hline erro quad. médio & \multicolumn{2}{|l|}{0,3988} \\
\hline pontuação & \multicolumn{2}{|l|}{2} \\
\hline
\end{tabular}


Tabela 5.1.10 Experimento com vizinhança esférica, um receptor oxigênio, arquitetura 48X12, normalizado.

\begin{tabular}{|c|c|c|}
\hline \multicolumn{3}{|c|}{ Arquitetura } \\
\hline $\begin{array}{l}1^{a} \text { camada } \\
\text { intermediária }\end{array}$ & $\begin{array}{l}2^{\text {a }} \text { camada } \\
\text { intermediária }\end{array}$ & $\begin{array}{l}\text { Camada } \\
\text { de saída }\end{array}$ \\
\hline 48 & 12 & 3 \\
\hline \multicolumn{3}{|c|}{ Divisão de dados } \\
\hline Treino $(\%)$ & Validação (\%) & Teste (\%) \\
\hline 80 & 10 & 10 \\
\hline \multicolumn{3}{|c|}{ DADOS DE TREINAMENTO } \\
\hline Resultado & $\begin{array}{l}\text { \% do total de padrões } \\
\text { do grupo }\end{array}$ & Quantidade de padrões \\
\hline ótimo & 9,9 & 335 \\
\hline bom & 20,1 & 679 \\
\hline ruim & 70 & 2369 \\
\hline erro quad. médio & \multicolumn{2}{|l|}{0,6616} \\
\hline pontuação & \multicolumn{2}{|l|}{1181} \\
\hline \multicolumn{3}{|c|}{ DADOS DE VALIDAÇÃO } \\
\hline Melhor época de validação & \multicolumn{2}{|l|}{4234} \\
\hline Resultado & $\begin{array}{l}\text { \% do total de padrões } \\
\text { do grupo }\end{array}$ & Quantidade de padrões \\
\hline ótimo & 10,2 & 43 \\
\hline bom & 18,5 & 78 \\
\hline ruim & 71,3 & 301 \\
\hline erro quad. médio & \multicolumn{2}{|l|}{0,7152} \\
\hline pontuação & \multicolumn{2}{|l|}{142} \\
\hline \multicolumn{3}{|c|}{ DADOS DE TESTE } \\
\hline Resultado & $\begin{array}{l}\text { \% do total de padrões } \\
\text { do grupo }\end{array}$ & Quantidade de padrões \\
\hline ótimo & 11,3 & 48 \\
\hline bom & 19,8 & 84 \\
\hline ruim & 68,9 & 292 \\
\hline erro quad. médio & \multicolumn{2}{|l|}{0,6860} \\
\hline pontuação & \multicolumn{2}{|l|}{156} \\
\hline
\end{tabular}


Capítulo 5 Experimentos

Tabela 5.1.11 Experimento com vizinhança esférica, um receptor oxigênio, arquitetura 48X24, não normalizado.

\begin{tabular}{|c|c|c|}
\hline \multicolumn{3}{|c|}{ Arquitetura } \\
\hline $\begin{array}{l}\mathbf{1}^{\text {a }} \text { camada } \\
\text { intermediária }\end{array}$ & $\begin{array}{l}2^{\text {a }} \text { camada } \\
\text { intermediária }\end{array}$ & $\begin{array}{l}\text { Camada } \\
\text { de saída }\end{array}$ \\
\hline 48 & 24 & 3 \\
\hline \multicolumn{3}{|c|}{ Divisão de dados } \\
\hline Treino $(\%)$ & Validação (\%) & Teste $(\%)$ \\
\hline 80 & 10 & 10 \\
\hline \multicolumn{3}{|c|}{ DADOS DE TREINAMENTO } \\
\hline Resultado & $\begin{array}{l}\text { \% do total de padrões } \\
\text { do grupo }\end{array}$ & Quantidade de padrões \\
\hline ótimo & 0,1 & 3 \\
\hline bom & 2,9 & 97 \\
\hline ruim & 97 & 3283 \\
\hline erro quad. médio & \multicolumn{2}{|l|}{0,3906} \\
\hline pontuação & \multicolumn{2}{|l|}{100} \\
\hline \multicolumn{3}{|c|}{ DADOS DE VALIDAÇÃO } \\
\hline Melhor época de validação & \multicolumn{2}{|l|}{4247} \\
\hline Resultado & $\begin{array}{l}\text { \% do total de padrões } \\
\text { do grupo }\end{array}$ & Quantidade de padrões \\
\hline ótimo & 0 & 0 \\
\hline bom & 0,2 & 1 \\
\hline ruim & 99,8 & 421 \\
\hline erro quad. médio & \multicolumn{2}{|l|}{0,4057} \\
\hline pontuação & \multicolumn{2}{|l|}{1} \\
\hline \multicolumn{3}{|c|}{ DADOS DE TESTE } \\
\hline Resultado & $\begin{array}{l}\text { \% do total de padrões } \\
\text { do grupo }\end{array}$ & Quantidade de padrões \\
\hline ótimo & 0 & 0 \\
\hline bom & 0,2 & 1 \\
\hline ruim & 99,8 & 423 \\
\hline erro quad. médio & \multicolumn{2}{|l|}{0,4015} \\
\hline pontuação & \multicolumn{2}{|l|}{1} \\
\hline
\end{tabular}


Tabela 5.1.12 Experimento com vizinhança esférica, um receptor oxigênio, arquitetura 48X24, normalizado.

\begin{tabular}{|c|c|c|}
\hline \multicolumn{3}{|c|}{ Arquitetura } \\
\hline $\begin{array}{l}1^{a} \text { camada } \\
\text { intermediária }\end{array}$ & $\begin{array}{l}2^{\text {a }} \text { camada } \\
\text { intermediária }\end{array}$ & $\begin{array}{l}\text { Camada } \\
\text { de saída }\end{array}$ \\
\hline 48 & 24 & 3 \\
\hline \multicolumn{3}{|c|}{ Divisão de dados } \\
\hline Treino (\%) & Validação (\%) & Teste (\%) \\
\hline 80 & 10 & 10 \\
\hline \multicolumn{3}{|c|}{ DADOS DE TREINAMENTO } \\
\hline Resultado & $\begin{array}{l}\text { \% do total de padrões } \\
\text { do grupo }\end{array}$ & Quantidade de padrões \\
\hline ótimo & 9,3 & 316 \\
\hline bom & 20,2 & 682 \\
\hline ruim & 70,5 & 2385 \\
\hline erro quad. médio & \multicolumn{2}{|l|}{0,6641} \\
\hline pontuação & \multicolumn{2}{|l|}{1156} \\
\hline \multicolumn{3}{|c|}{ DADOS DE VALIDAÇÃO } \\
\hline Melhor época de validação & \multicolumn{2}{|l|}{4247} \\
\hline Resultado & $\begin{array}{l}\text { \% do total de padrões } \\
\text { do grupo }\end{array}$ & Quantidade de padrões \\
\hline ótimo & 9.5 & 40 \\
\hline bom & 18 & 76 \\
\hline ruim & 72,5 & 306 \\
\hline erro quad. médio & \multicolumn{2}{|l|}{0,7230} \\
\hline pontuação & \multicolumn{2}{|l|}{136} \\
\hline \multicolumn{3}{|c|}{ DADOS DE TESTE } \\
\hline Resultado & $\begin{array}{l}\text { \% do total de padrões } \\
\text { do grupo }\end{array}$ & Quantidade de padrões \\
\hline ótimo & 9,2 & 15 \\
\hline bom & 20,8 & 88 \\
\hline ruim & 70,0 & 297 \\
\hline erro quad. médio & \multicolumn{2}{|l|}{0,7002} \\
\hline pontuação & \multicolumn{2}{|l|}{146} \\
\hline
\end{tabular}


Como podemos observar nas tabelas 5.1.5 a 5.1.12, os resultados dos experimentos usando a vizinhança com formato esférico foram muito ruins. Deseja-se que um classificador apresente, ao menos, uma taxa de acerto no intervalo de $80 \%$ a $85 \%$ para resultados bons e ótimos, mas o desempenho obtido ficou muito abaixo deste limite.

Considerando-se que a esfera está centrada no átomo doador, uma possível justificativa, imaginada na época dos experimentos, foi que a existência de átomos receptores dentro da esfera mas longe do átomo hidrogênio, poderiam ter provocado ruído na fase de treinamento da rede neural. $\mathrm{O}$ uso da vizinhança com formato em toro esclareceria se esta justificativa estava correta, isto é, esperava-se uma melhora nos resultados com a vizinhança em toro. Na seção seguinte veremos os resultados com o uso do formato de toro para a vizinhança.

\subsection{Vizinhança em toro}

Conforme vimos na seção anterior, o uso da vizinhança esférica não funcionou adequadamente. $\mathrm{O}$ uso da vizinhança em toro, restringindo os receptores a estarem próximos do orbital do hidrogênio, teoricamente deve produzir resultados melhores.

Trinta e um experimentos foram executados usando a configuração: vizinhança em toro com raio de 2,5 $\AA$ em torno do orbital do hidrogênio, nomeação de receptores por projeção escalar, agrupamento de dados com o uso de mapa de Kohonen com grade quadrada de tamanho 10 e superposição de padrões com o uso de algoritmos genéticos, para obter-se os dados de entrada da rede MLP. Os experimentos foram feitos usando-se redes neurais com parâmetros análogos aos experimentos com a vizinhança esférica. Contrariamente ao que havia sido imaginado, os resultados foram ruins. Não houve melhora significativa em comparação com os resultados da vizinhança esférica.

As tabelas 5.2.1 e 5.2.2, 5.2.3 e 5.2.4, 5.2.5 e 5.2.6, 5.2.7 e 5.2.8 mostram o resultado de experimentos com dados não normalizado e normalizados, usando arquiteturas $12 \mathrm{X} 12$, 24X24, 48X12 e 48X24, respectivamente, onde o primeiro número indica a quantidade de neurônios da primeira camada intermediária e o segundo número indica a quantidade na segunda camada intermediária. Nestes quatro experimentos usou-se $80 \%$ dos padrões para treino, $10 \%$ para validação e $10 \%$ para teste. Os parâmetros contidos na tabela 5.1 .3 da seção 5.1 foram usados com os mesmos valores iniciais contidos na tabela citada. 
Capítulo 5 Experimentos

Tabela 5.2.1 Experimento com vizinhança em toro, um receptor oxigênio, arquitetura 12X12, não normalizado.

\begin{tabular}{|c|c|c|}
\hline \multicolumn{3}{|c|}{ Arquitetura } \\
\hline $\begin{array}{l}\mathbf{1}^{\text {a }} \text { camada } \\
\text { intermediária }\end{array}$ & $\begin{array}{l}2^{\text {a }} \text { camada } \\
\text { intermediária }\end{array}$ & $\begin{array}{l}\text { Camada } \\
\text { de saída }\end{array}$ \\
\hline 12 & 12 & 3 \\
\hline \multicolumn{3}{|c|}{ Divisão de dados } \\
\hline Treino $(\%)$ & Validação (\%) & Teste $(\%)$ \\
\hline 80 & 10 & 10 \\
\hline \multicolumn{3}{|c|}{ DADOS DE TREINAMENTO } \\
\hline Resultado & $\begin{array}{l}\text { \% do total de padrões } \\
\text { do grupo }\end{array}$ & Quantidade de padrões \\
\hline ótimo & 0 & 0 \\
\hline bom & 8,5 & 423 \\
\hline ruim & 91,5 & 4528 \\
\hline erro quad. médio & \multicolumn{2}{|l|}{0,3775} \\
\hline pontuação & \multicolumn{2}{|l|}{423} \\
\hline \multicolumn{3}{|c|}{ DADOS DE VALIDAÇÃO } \\
\hline Melhor época de validação & \multicolumn{2}{|l|}{4439} \\
\hline Resultado & $\begin{array}{l}\text { \% do total de padrões } \\
\text { do grupo }\end{array}$ & Quantidade de padrões \\
\hline ótimo & 0 & 0 \\
\hline bom & 3,7 & 23 \\
\hline ruim & 96,3 & 595 \\
\hline erro quad. médio & \multicolumn{2}{|l|}{0,3880} \\
\hline pontuação & \multicolumn{2}{|l|}{23} \\
\hline \multicolumn{3}{|c|}{ DADOS DE TESTE } \\
\hline Resultado & $\begin{array}{l}\text { \% do total de padrões } \\
\text { do grupo }\end{array}$ & Quantidade de padrões \\
\hline ótimo & 0 & 0 \\
\hline bom & 4 & 25 \\
\hline ruim & 96 & 595 \\
\hline erro quad. médio & \multicolumn{2}{|l|}{0,3906} \\
\hline pontuação & \multicolumn{2}{|l|}{25} \\
\hline
\end{tabular}


Tabela 5.2.2 Experimento com vizinhança em toro, um receptor oxigênio, arquitetura 12X12, normalizado.

\begin{tabular}{|c|c|c|}
\hline \multicolumn{3}{|c|}{ Arquitetura } \\
\hline $\begin{array}{l}\mathbf{1}^{\text {a }} \text { camada } \\
\text { intermediária }\end{array}$ & $\begin{array}{l}2^{\text {a }} \text { camada } \\
\text { intermediária }\end{array}$ & $\begin{array}{l}\text { Camada } \\
\text { de saída }\end{array}$ \\
\hline 12 & 12 & 3 \\
\hline \multicolumn{3}{|c|}{ Divisão de dados } \\
\hline Treino $(\%)$ & Validação (\%) & Teste $(\%)$ \\
\hline 80 & 10 & 10 \\
\hline \multicolumn{3}{|c|}{ DADOS DE TREINAMENTO } \\
\hline Resultado & $\begin{array}{l}\text { \% do total de padrões } \\
\text { do grupo }\end{array}$ & Quantidade de padrões \\
\hline ótimo & 10,6 & 524 \\
\hline bom & 21 & 1040 \\
\hline ruim & 68,4 & 3387 \\
\hline erro quad. médio & \multicolumn{2}{|l|}{0,6138} \\
\hline pontuação & \multicolumn{2}{|l|}{1826} \\
\hline \multicolumn{3}{|c|}{ DADOS DE VALIDAÇÃO } \\
\hline Melhor época de validação & \multicolumn{2}{|l|}{4439} \\
\hline Resultado & $\begin{array}{l}\text { \% do total de padrões } \\
\text { do grupo }\end{array}$ & Quantidade de padrões \\
\hline ótimo & 10,5 & 65 \\
\hline bom & 23,8 & 147 \\
\hline ruim & 65,7 & 406 \\
\hline erro quad. médio & \multicolumn{2}{|l|}{0,6163} \\
\hline \multicolumn{3}{|l|}{ pontuação } \\
\hline \multicolumn{3}{|c|}{ DADOS DE TESTE } \\
\hline Resultado & $\begin{array}{l}\text { \% do total de padrões } \\
\text { do grupo }\end{array}$ & Quantidade de padrões \\
\hline ótimo & 9,2 & 57 \\
\hline bom & 19,7 & 122 \\
\hline ruim & 71,1 & 441 \\
\hline erro quad. médio & 0,6093 & \\
\hline pontuação & & \\
\hline
\end{tabular}


Capítulo 5 Experimentos

Tabela 5.2.3 Experimento com vizinhança em toro, um receptor oxigênio, arquitetura 24X24, não normalizado.

\begin{tabular}{|c|c|c|}
\hline \multicolumn{3}{|c|}{ Arquitetura } \\
\hline $\begin{array}{l}\mathbf{1}^{\text {a }} \text { camada } \\
\text { intermediária }\end{array}$ & $\begin{array}{l}2^{\text {a }} \text { camada } \\
\text { intermediária }\end{array}$ & $\begin{array}{l}\text { Camada } \\
\text { de saída }\end{array}$ \\
\hline 24 & 24 & 3 \\
\hline \multicolumn{3}{|c|}{ Divisão de dados } \\
\hline Treino $(\%)$ & Validação (\%) & Teste $(\%)$ \\
\hline 80 & 10 & 10 \\
\hline \multicolumn{3}{|c|}{ DADOS DE TREINAMENTO } \\
\hline Resultado & $\begin{array}{l}\text { \% do total de padrões } \\
\text { do grupo }\end{array}$ & Quantidade de padrões \\
\hline ótimo & 0 & 0 \\
\hline bom & 8,4 & 416 \\
\hline ruim & 91,6 & 4535 \\
\hline erro quad. médio & \multicolumn{2}{|l|}{0,3777} \\
\hline pontuação & \multicolumn{2}{|l|}{416} \\
\hline \multicolumn{3}{|c|}{ DADOS DE VALIDAÇÃO } \\
\hline Melhor época de validação & \multicolumn{2}{|l|}{8476} \\
\hline Resultado & $\begin{array}{l}\text { \% do total de padrões } \\
\text { do grupo }\end{array}$ & Quantidade de padrões \\
\hline ótimo & 0 & 0 \\
\hline bom & 6,3 & 39 \\
\hline ruim & 93,7 & 579 \\
\hline erro quad. médio & \multicolumn{2}{|l|}{0,3844} \\
\hline pontuação & \multicolumn{2}{|l|}{39} \\
\hline \multicolumn{3}{|c|}{ DADOS DE TESTE } \\
\hline Resultado & $\begin{array}{l}\text { \% do total de padrões } \\
\text { do grupo }\end{array}$ & Quantidade de padrões \\
\hline ótimo & 0 & 0 \\
\hline bom & 7,3 & 45 \\
\hline ruim & 92,7 & 575 \\
\hline erro quad. médio & \multicolumn{2}{|l|}{0,3897} \\
\hline pontuação & \multicolumn{2}{|l|}{45} \\
\hline
\end{tabular}


Tabela 5.2.4 Experimento com vizinhança em toro, um receptor oxigênio, arquitetura $24 X 24$, normalizado.

\begin{tabular}{|c|c|c|}
\hline \multicolumn{3}{|c|}{ Arquitetura } \\
\hline $\begin{array}{l}\mathbf{1}^{\text {a }} \text { camada } \\
\text { intermediária }\end{array}$ & $\begin{array}{l}2^{\text {a }} \text { camada } \\
\text { intermediária }\end{array}$ & $\begin{array}{l}\text { Camada } \\
\text { de saída }\end{array}$ \\
\hline 24 & 24 & 3 \\
\hline \multicolumn{3}{|c|}{ Divisão de dados } \\
\hline Treino $(\%)$ & Validação (\%) & Teste $(\%)$ \\
\hline 80 & 10 & 10 \\
\hline \multicolumn{3}{|c|}{ DADOS DE TREINAMENTO } \\
\hline Resultado & $\begin{array}{l}\text { \% do total de padrões } \\
\text { do grupo }\end{array}$ & Quantidade de padrões \\
\hline ótimo & 10,6 & 527 \\
\hline bom & 20,7 & 1025 \\
\hline ruim & 68,7 & 3399 \\
\hline erro quad. médio & \multicolumn{2}{|l|}{0,6137} \\
\hline pontuação & \multicolumn{2}{|l|}{1815} \\
\hline \multicolumn{3}{|c|}{ DADOS DE VALIDAÇÃO } \\
\hline Melhor época de validação & \multicolumn{2}{|l|}{8476} \\
\hline Resultado & $\begin{array}{l}\text { \% do total de padrões } \\
\text { do grupo }\end{array}$ & Quantidade de padrões \\
\hline ótimo & 12,3 & 76 \\
\hline bom & 22 & 136 \\
\hline ruim & 65,7 & 406 \\
\hline erro quad. médio & \multicolumn{2}{|l|}{0,6216} \\
\hline pontuação & \multicolumn{2}{|l|}{250} \\
\hline \multicolumn{3}{|c|}{ DADOS DE TESTE } \\
\hline Resultado & $\begin{array}{l}\text { \% do total de padrões } \\
\text { do grupo }\end{array}$ & Quantidade de padrões \\
\hline ótimo & 10,3 & 64 \\
\hline bom & 21,1 & 131 \\
\hline ruim & 68,5 & 425 \\
\hline erro quad. médio & \multicolumn{2}{|l|}{0,6355} \\
\hline pontuação & \multicolumn{2}{|l|}{227} \\
\hline
\end{tabular}


Capítulo 5 Experimentos

Tabela 5.2.5 Experimento com vizinhança em toro, um receptor oxigênio, arquitetura 48X12, não normalizado.

\begin{tabular}{|c|c|c|}
\hline \multicolumn{3}{|c|}{ Arquitetura } \\
\hline $\begin{array}{l}\mathbf{1}^{\text {a }} \text { camada } \\
\text { intermediária }\end{array}$ & $\begin{array}{l}2^{\text {a }} \text { camada } \\
\text { intermediária }\end{array}$ & $\begin{array}{l}\text { Camada } \\
\text { de saída }\end{array}$ \\
\hline 48 & 12 & 3 \\
\hline \multicolumn{3}{|c|}{ Divisão de dados } \\
\hline Treino $(\%)$ & Validação (\%) & Teste $(\%)$ \\
\hline 80 & 10 & 10 \\
\hline \multicolumn{3}{|c|}{ DADOS DE TREINAMENTO } \\
\hline Resultado & $\begin{array}{l}\text { \% do total de padrões } \\
\text { do grupo }\end{array}$ & Quantidade de padrões \\
\hline ótimo & 0 & 2 \\
\hline bom & 8,5 & 423 \\
\hline ruim & 91,4 & 4526 \\
\hline erro quad. médio & \multicolumn{2}{|l|}{0,3770} \\
\hline pontuação & \multicolumn{2}{|l|}{425} \\
\hline \multicolumn{3}{|c|}{ DADOS DE VALIDAÇÃO } \\
\hline Melhor época de validação & \multicolumn{2}{|l|}{8441} \\
\hline Resultado & $\begin{array}{l}\text { \% do total de padrões } \\
\text { do grupo }\end{array}$ & Quantidade de padrões \\
\hline ótimo & 0 & 0 \\
\hline bom & 6,1 & 38 \\
\hline ruim & 93,9 & 580 \\
\hline erro quad. médio & \multicolumn{2}{|l|}{0,3858} \\
\hline pontuação & \multicolumn{2}{|l|}{38} \\
\hline \multicolumn{3}{|c|}{ DADOS DE TESTE } \\
\hline Resultado & $\begin{array}{l}\text { \% do total de padrões } \\
\text { do grupo }\end{array}$ & Quantidade de padrões \\
\hline ótimo & 0 & 0 \\
\hline bom & 7,33 & 45 \\
\hline ruim & 92,7 & 575 \\
\hline erro quad. médio & \multicolumn{2}{|l|}{0,3919} \\
\hline pontuação & \multicolumn{2}{|l|}{45} \\
\hline
\end{tabular}


Tabela 5.2.6 Experimento com vizinhança em toro, um receptor oxigênio, arquitetura 48X12, normalizado.

\begin{tabular}{|c|c|c|}
\hline \multicolumn{3}{|c|}{ Arquitetura } \\
\hline $\begin{array}{l}\mathbf{1}^{\text {a }} \text { camada } \\
\text { intermediária }\end{array}$ & $\begin{array}{l}2^{\text {a }} \text { camada } \\
\text { intermediária }\end{array}$ & $\begin{array}{l}\text { Camada } \\
\text { de saída }\end{array}$ \\
\hline 48 & 12 & 3 \\
\hline \multicolumn{3}{|c|}{ Divisão de dados } \\
\hline Treino $(\%)$ & Validação (\%) & Teste $(\%)$ \\
\hline 80 & 10 & 10 \\
\hline \multicolumn{3}{|c|}{ DADOS DE TREINAMENTO } \\
\hline Resultado & $\begin{array}{l}\text { \% do total de padrões } \\
\text { do grupo }\end{array}$ & Quantidade de padrões \\
\hline ótimo & 10,5 & 519 \\
\hline bom & 21,2 & 1052 \\
\hline ruim & 68,3 & 3380 \\
\hline erro quad. médio & \multicolumn{2}{|l|}{0,6122} \\
\hline pontuação & \multicolumn{2}{|l|}{1830} \\
\hline \multicolumn{3}{|c|}{ DADOS DE VALIDAÇÃO } \\
\hline Melhor época de validação & \multicolumn{2}{|l|}{8441} \\
\hline Resultado & $\begin{array}{l}\text { \% do total de padrões } \\
\text { do grupo }\end{array}$ & Quantidade de padrões \\
\hline ótimo & 12 & 74 \\
\hline bom & 21,4 & 132 \\
\hline ruim & 66,7 & 412 \\
\hline erro quad. médio & \multicolumn{2}{|l|}{0,6295} \\
\hline pontuação & \multicolumn{2}{|l|}{243} \\
\hline \multicolumn{3}{|c|}{ DADOS DE TESTE } \\
\hline Resultado & $\begin{array}{l}\text { \% do total de padrões } \\
\text { do grupo }\end{array}$ & Quantidade de padrões \\
\hline ótimo & 11 & 68 \\
\hline bom & 20,3 & 126 \\
\hline ruim & 68,7 & 426 \\
\hline erro quad. médio & \multicolumn{2}{|l|}{0,6417} \\
\hline pontuação & \multicolumn{2}{|l|}{228} \\
\hline
\end{tabular}


Capítulo 5 Experimentos

Tabela 5.2.7 Experimento com vizinhança em toro, um receptor oxigênio, arquitetura 48X24, não normalizado.

\begin{tabular}{|c|c|c|}
\hline \multicolumn{3}{|c|}{ Arquitetura } \\
\hline $\begin{array}{l}\mathbf{1}^{\text {a }} \text { camada } \\
\text { intermediária }\end{array}$ & $\begin{array}{l}2^{\text {a }} \text { camada } \\
\text { intermediária }\end{array}$ & $\begin{array}{l}\text { Camada } \\
\text { de saída }\end{array}$ \\
\hline 48 & 24 & 3 \\
\hline \multicolumn{3}{|c|}{ Divisão de dados } \\
\hline Treino $(\%)$ & Validação (\%) & Teste $(\%)$ \\
\hline 80 & 10 & 10 \\
\hline \multicolumn{3}{|c|}{ DADOS DE TREINAMENTO } \\
\hline Resultado & $\begin{array}{l}\text { \% do total de padrões } \\
\text { do grupo }\end{array}$ & Quantidade de padrões \\
\hline ótimo & 0,1 & 3 \\
\hline bom & 9,1 & 451 \\
\hline ruim & 90,8 & 4497 \\
\hline erro quad. médio & \multicolumn{2}{|l|}{0,3754} \\
\hline pontuação & \multicolumn{2}{|l|}{454} \\
\hline \multicolumn{3}{|c|}{ DADOS DE VALIDAÇÃO } \\
\hline Melhor época de validação & \multicolumn{2}{|l|}{6866} \\
\hline Resultado & $\begin{array}{l}\text { \% do total de padrões } \\
\text { do grupo }\end{array}$ & Quantidade de padrões \\
\hline ótimo & 0 & 0 \\
\hline bom & 4 & 25 \\
\hline ruim & 96 & 593 \\
\hline erro quad. médio & \multicolumn{2}{|l|}{0,3895} \\
\hline pontuação & \multicolumn{2}{|l|}{25} \\
\hline \multicolumn{3}{|c|}{ DADOS DE TESTE } \\
\hline Resultado & $\begin{array}{l}\text { \% do total de padrões } \\
\text { do grupo }\end{array}$ & Quantidade de padrões \\
\hline ótimo & 0 & 0 \\
\hline bom & 5,3 & 33 \\
\hline ruim & 94,7 & 587 \\
\hline erro quad. médio & \multicolumn{2}{|l|}{0,3958} \\
\hline pontuação & \multicolumn{2}{|l|}{33} \\
\hline
\end{tabular}


Tabela 5.2.8 Experimento com vizinhança em toro, um receptor oxigênio, arquitetura 48X24, normalizado.

\begin{tabular}{|c|c|c|}
\hline \multicolumn{3}{|c|}{ Arquitetura } \\
\hline $\begin{array}{l}\mathbf{1}^{\text {a }} \text { camada } \\
\text { intermediária }\end{array}$ & $\begin{array}{l}2^{\text {a }} \text { camada } \\
\text { intermediária }\end{array}$ & $\begin{array}{l}\text { Camada } \\
\text { de saída }\end{array}$ \\
\hline 48 & 24 & 3 \\
\hline \multicolumn{3}{|c|}{ Divisão de dados } \\
\hline Treino $(\%)$ & Validação (\%) & Teste $(\%)$ \\
\hline 80 & 10 & 10 \\
\hline \multicolumn{3}{|c|}{ DADOS DE TREINAMENTO } \\
\hline Resultado & $\begin{array}{l}\text { \% do total de padrões } \\
\text { do grupo }\end{array}$ & Quantidade de padrões \\
\hline ótimo & 10,3 & 511 \\
\hline bom & 20,7 & 1026 \\
\hline ruim & 69 & 3414 \\
\hline erro quad. médio & \multicolumn{2}{|l|}{0,6127} \\
\hline pontuação & \multicolumn{2}{|l|}{1792} \\
\hline \multicolumn{3}{|c|}{ DADOS DE VALIDAÇÃO } \\
\hline Melhor época de validação & \multicolumn{2}{|l|}{6866} \\
\hline Resultado & $\begin{array}{l}\text { \% do total de padrões } \\
\text { do grupo }\end{array}$ & Quantidade de padrões \\
\hline ótimo & 12,1 & 75 \\
\hline bom & 21,5 & 133 \\
\hline ruim & 66,3 & 410 \\
\hline erro quad. médio & \multicolumn{2}{|l|}{0,6249} \\
\hline pontuação & \multicolumn{2}{|l|}{245} \\
\hline \multicolumn{3}{|c|}{ DADOS DE TESTE } \\
\hline Resultado & $\begin{array}{l}\text { \% do total de padrões } \\
\text { do grupo }\end{array}$ & Quantidade de padrões \\
\hline ótimo & 10,3 & 64 \\
\hline bom & 19,8 & 123 \\
\hline ruim & 69,8 & 433 \\
\hline erro quad. médio & \multicolumn{2}{|l|}{0,6378} \\
\hline pontuação & \multicolumn{2}{|l|}{219} \\
\hline
\end{tabular}


O baixo nível de acerto com o uso da vizinhança em toro, contrariamente à expectativa de melhoria, conduziu a um questionamento da metodologia utilizada. Considerando que diversos experimentos com diferentes arquiteturas de rede MLP foram tentados, aparentemente o erro não estava na rede, a menos que houvesse erros de implementação. Testes usando o problema do cálculo do valor do ponto médio entre três pontos foram executados, e não encontrou-se problemas com a implementação. Com a introdução de ruído nos dados de teste, o desempenho da rede caiu drasticamente, enquanto o treino sem ruído apresentou acerto total do ponto médio.

Estes resultados conduziram a uma mudança de metodologia, descrita na próxima seção.

\subsection{Vizinhança em toro com fusão de grupos em 2 fases}

Três possibilidades foram consideradas para justificar o baixo desempenho da rede para a vizinhança em toro com a configuração descrita na seção anterior: a existência de ruído nos dados experimentais; o problema ser complexo demais para o uso de redes neurais; o preprocessamento dos dados de entrada da rede estar ruim, confundindo o treinamento.

As duas primeiras situações são muito difíceis de serem analisadas e contornadas. Assim, por exclusão, atacou-se a terceira situação: criou-se o método de nomeação por paridade de vizinhanças em substituição à nomeação por projeção escalar, e o algoritmo de fusão de grupo em duas fases em substituição ao agrupamento por mapa de Kohonen.

Com estas alterações finalmente conseguiu-se um aumento de resultados bons e excelentes, com alta acuracidade de acertos em alguns casos. A porcentagem de resultados ótimos e bons em geral é superior a $80 \%$, indicando que a rede tornou-se um bom classificador. O custo computacional foi reduzido enormemente: antes das alterações mencionadas havia a necessidade de milhares de épocas para o treinamento da rede para se encontrar a melhor época de validação; depois das alterações, em geral, a melhor época fica entre as dez primeiras, muitas vezes sendo a primeira época do treino. Pela primeira vez, os resultados produzidos pela rede, em alguns experimentos, tornaram-se melhores que os resultados normalizados pelo comprimento médio da ligação doador-hidrogênio calculado para o agrupamento.

A tabela 5.3.1 mostra os resultados do treinamento de alguns grupos usando-se 15 grupos na fase 1 e 50 na fase 2 (total teórico de $15 \times 50=750$, mas na fase 2 alguns grupos ficaram vazios). Os grupos contêm apenas um receptor oxigênio. A arquitetura da rede é de 48 neurônios na primeira camada intermediária e 24 na segunda camada intermediária. Na 
tabela o campo Grupo mostra o número do grupo da fase 1 seguido do número da fase 2. Tamanho é a quantidade de padrões do grupo e desvio é o desvio linear médio das distâncias entre pares de átomos dos padrões, comparadas com as distâncias médias do grupo. Mel. ép. Val. é a melhor época de validação, \%treino é a porcentagem dos padrões do grupo usados para treinamento, \%val. é a porcentagem para validação e \%teste a porcentagem para teste. $E Q M$ é o erro quadrático médio. Na tabela, também é mostrada a porcentagem de resultados ótimos, bons e ruins para os dados de teste. Dados não normalizados são os dados calculados pela rede neural e dados normalizados são os dados alterados para apresentar o comprimento médio da ligação doador_hidrogênio calculado para o grupo. Lembremos da tabela 5.1 .4 (seção 5.1) que os resultados são ótimos quando o EQM é menor ou igual $0.1 \AA$, bom entre 0.1 e $0.3 \AA$ e ruim quando maior de $0.3 \AA$. Entretanto, como estamos considerando o valor médio, isto não significa necessariamente que todos os resultados caiam na mesma faixa, por exemplo, um erro linear médio de 0.097 pode ser constituído de $75 \%$ de resultados ótimos e $25 \%$ de resultados bons.

Tabela 5.3.1 Experimentos com algorimo de fusão de grupo, com 15 grupos na primeira fase e 50 na segunda fase.

\begin{tabular}{|c|c|c|c|c|c|c|}
\hline Grupo & Tamanho & Desvio & Mel.ép. val. & $\%$ Treino & \%Validação & \%Teste \\
\hline 00_01 & 412 & 0,729 & 1 & 80 & 10 & 10 \\
\hline Dados & EQM(treino) & EQM(val.) & EQM (teste) & \%ót. (teste) & \%bom(teste) & \%ruim(teste) \\
\hline Não normal. & 0,0142 & 0,0001 & 0,0000 & 100 & 0 & 0 \\
\hline Normalizado & 0,0144 & 0,0001 & 0,0000 & 100 & 0 & 0 \\
\hline grupo & Tamanho & Desvio & Mel.ép. val. & \%Treino & \%Validação & \%Teste \\
\hline $00 \_25$ & 27 & 0,458 & 3 & 60 & 20 & 20 \\
\hline Dados & $E Q M($ treino $)$ & $E Q M(v a l)$. & EQM (teste) & \%ót. (teste) & \%bom(teste) & \%ruim(teste) \\
\hline Não normal. & 0,1140 & 0,0195 & 0,0163 & 83,3 & 16,7 & 0 \\
\hline Normalizado & 0,1217 & 0,0150 & 0,0114 & 100 & 0 & 0 \\
\hline grupo & Tamanho & Desvio & Mel. ép. val. & \%Treino & \%Validação & \%Teste \\
\hline $00 \_47$ & 110 & 1,023 & 1 & 80 & 10 & 10 \\
\hline Dados & EQM(treino) & $E Q M($ val. $)$ & EQM (teste) & \%ót. (teste) & \%bom(teste) & \%ruim(teste) \\
\hline Não normal. & 0,0097 & 0,0084 & 0,0084 & 100 & 0 & 0 \\
\hline Normalizado & 0,0097 & 0,0084 & 0,0084 & 100 & 0 & 0 \\
\hline grupo & Tamanho & Desvio & Mel. ép. val. & \%Treino & \%Validação & \%Teste \\
\hline $12 \_23$ & 491 & 0,737 & 5 & 80 & 10 & 10 \\
\hline
\end{tabular}


Capítulo 5 Experimentos

\begin{tabular}{|c|c|c|c|c|c|c|}
\hline Dados & EQM(treino) & EQM(val.) & EQM (teste) & \%ót. (teste) & \%bom(teste) & \%ruim(teste) \\
\hline Não normal. & 0,1115 & 0,1039 & 0,1189 & 0 & 100 & 0 \\
\hline Normalizado & 0,1207 & 0,1123 & 0,1278 & 0 & 64 & 36 \\
\hline grupo & Tamanho & Desvio & Mel. ép. val. & $\%$ Treino & \%Validação & \%Teste \\
\hline $12 \_44$ & 1490 & 0,591 & 99 & 50 & 25 & 25 \\
\hline Dados & $E Q M($ treino $)$ & $E Q M(v a l)$. & EQM (teste) & \%ót. (teste) & \%bom(teste) & \%ruim(teste) \\
\hline Não normal. & 0,0183 & 0,0174 & 0,0162 & 98,4 & 1,6 & 0 \\
\hline Normalizado & 0,0176 & 0,0160 & 0,0150 & 95,4 & 4,6 & 0 \\
\hline grupo & Tamanho & Desvio & Mel. ép. val. & \%Treino & \%Validação & \%Teste \\
\hline $12 \_44$ & 1490 & 0,591 & 1 & 80 & 10 & 10 \\
\hline Dados & $E Q M($ treino $)$ & $E Q M($ val. $)$ & EQM (teste) & \%ót. (teste) & \%bom(teste) & \%ruim(teste) \\
\hline Não normal. & 0,0169 & 0,0156 & 0,0154 & 97,3 & 2,7 & 0 \\
\hline Normalizado & 0,0171 & 0,0153 & 0,0152 & 94,6 & 5,4 & 0 \\
\hline grupo & Tamanho & Desvio & Mel. ép. val. & \%Treino & \%Validação & \%Teste \\
\hline $12 \_46$ & 181 & 1,003 & 8 & 80 & 20 & 20 \\
\hline Dados & $E Q M($ treino $)$ & $E Q M(v a l)$. & EQM (teste) & \%ót. (teste) & \%bom(teste) & \%ruim(teste) \\
\hline Não normal. & 0,1192 & 0,1263 & 0,1317 & 0 & 89,5 & 10,5 \\
\hline Normalizado & 0,1296 & 0,1369 & 0,1416 & 0 & 52,6 & 47,4 \\
\hline grupo & Tamanho & Desvio & Mel. ép. val. & $\%$ Treino & \%Validação & \%Teste \\
\hline $13 \_42$ & 5435 & 0,869 & 1 & 80 & 10 & 10 \\
\hline Dados & $E Q M($ treino $)$ & $E Q M(v a l)$. & EQM (teste) & \%ót. (teste) & \%bom(teste) & \%ruim(teste) \\
\hline Não normal. & 0,0030 & 0,0002 & 0,0027 & 99,8 & 0 & 0,2 \\
\hline Normalizado & 0,0030 & 0,0001 & 0,0027 & 99,8 & 0 & 0,2 \\
\hline grupo & Tamanho & Desvio & Mel. ép. val. & \%Treino & \%Validação & \%Teste \\
\hline $13 \_46$ & 6116 & 0,849 & 1 & 80 & 10 & 10 \\
\hline Dados & $E Q M($ treino $)$ & $E Q M(v a l)$. & EQM (teste) & \%ót. (teste) & \%bom(teste) & $\%$ ruim(teste) \\
\hline Não normal. & 0,1147 & 0,1116 & 0,1016 & 0 & 74,2 & 25,8 \\
\hline Normalizado & 0,1238 & 0,1200 & 0,1085 & 0 & 74,2 & 25,8 \\
\hline
\end{tabular}


A tabela 5.3.2 mostra os resultados do treinamento de alguns grupos usando-se 30 grupos na fase 1 e 75 na fase 2 (total teórico de 30X75=2250, mas na fase 2 alguns grupos ficaram vazios). Os grupos contêm apenas um receptor oxigênio. A arquitetura da rede é de 48 neurônios na primeira camada intermediária e 24 na segunda camada intermediária. Os campos são definidos da mesma maneira como foram explicados para a tabela 5.3.1.

Tabela 5.3.2 Experimentos com algorimo de fusão de grupo, com 30 grupos na primeira fase e 75 na segunda fase.

\begin{tabular}{|c|c|c|c|c|c|c|}
\hline Grupo & Tamanho & Desvio & Mel. ép. val. & \%Treino & \%Validação & \%Teste \\
\hline 09_07 & 26 & 0,584 & 7 & 50 & 25 & 25 \\
\hline Dados & $E Q M($ treino $)$ & EQM(val.) & EQM (teste) & \%ót. (teste) & \%bom(teste) & \%ruim(teste) \\
\hline Não normal. & 0,0098 & 0,0145 & 0,0126 & 100 & 0 & 0 \\
\hline Normalizado & 0,0099 & 0,0112 & 0,0095 & 100 & 0 & 0 \\
\hline Grupo & Tamanho & Desvio & Mel. ép. val. & \%Treino & \%Validação & \%Teste \\
\hline 09_07 & 26 & 0,584 & 4 & 80 & 10 & 10 \\
\hline Dados & $E Q M($ treino $)$ & $E Q M(v a l)$. & EQM (teste) & \%ót. (teste) & \%bom(teste) & \%ruim(teste) \\
\hline Não normal. & 0,0102 & 0,0123 & 0,0148 & 75 & 25 & 0 \\
\hline Normalizado & 0,0103 & 0,0076 & 0,0093 & 100 & 0 & 0 \\
\hline Grupo & Tamanho & Desvio & Mel. ép. val. & \%Treino & \%Validação & \%Teste \\
\hline $09 \_72$ & 805 & 0,361 & 1 & 50 & 25 & 25 \\
\hline Dados & EQM(treino) & EQM(val.) & EQM (teste) & \%ót. (teste) & \%bom(teste) & \%ruim(teste) \\
\hline Não normal. & 0,0204 & 0,0130 & 0,0125 & 79,2 & 20,8 & 0 \\
\hline Normalizado & 0,0205 & 0,0132 & 0,0120 & 78,2 & 21,8 & 0 \\
\hline Grupo & Tamanho & Desvio & Mel.ép. val. & $\%$ Treino & \%Validação & \%Teste \\
\hline 09_72 & 805 & 0,361 & 1 & 80 & 10 & 10 \\
\hline Dados & EQM(treino) & $E Q M(v a l)$. & EQM (teste) & \%ót. (teste) & \%bom(teste) & \%ruim(teste) \\
\hline Não normal. & 0,0166 & 0,0152 & 0,0212 & 74,1 & 25,9 & 0 \\
\hline Normalizado & 0,0167 & 0,0148 & 0,0200 & 74,1 & 25,9 & 0 \\
\hline Grupo & Tamanho & Desvio & Mel. ép. val. & $\%$ Treino & \%Validação & \%Teste \\
\hline 17_38 & 329 & 0,441 & 3 & 80 & 10 & 10 \\
\hline Dados & $E Q M($ treino $)$ & $E Q M(v a l)$. & EQM (teste) & \%ót. (teste) & \%bom(teste) & \%ruim(teste) \\
\hline Não normal. & 0,0400 & 0,0628 & 0,0496 & 73,5 & 23,5 & 2,9 \\
\hline
\end{tabular}


Capítulo 5 Experimentos

\begin{tabular}{|c|c|c|c|c|c|c|}
\hline Normalizado & 0,0395 & 0,0554 & 0,0448 & 73,5 & 26,5 & 0 \\
\hline Grupo & Tamanho & Desvio & Mel.ép. val. & \%Treino & \%Validação & \%Teste \\
\hline $17 \_40$ & 163 & 0,413 & 1 & 80 & 10 & 10 \\
\hline Dados & $E Q M($ treino $)$ & $E Q M(v a l)$. & EQM (teste) & \%ót. (teste) & \%bom(teste) & \%ruim(teste) \\
\hline Não normal. & 0,0267 & 0,0146 & 0,0145 & 94,1 & 5,9 & 0 \\
\hline Normalizado & 0,0269 & 0,0142 & 0,0153 & 94,1 & 5,9 & 0 \\
\hline Grupo & Tamanho & Desvio & Mel. ép. val. & \%Treino & \%Validação & $\%$ Teste \\
\hline $18 \_27$ & 117 & 0,638 & 1 & 80 & 10 & 10 \\
\hline Dados & $E Q M($ treino $)$ & $E Q M(v a l)$. & EQM (teste) & \%ót. (teste) & \%bom(teste) & \%ruim(teste) \\
\hline Não normal. & 0,0036 & 0,0028 & 0,0028 & 100 & 0 & 0 \\
\hline Normalizado & 0,0036 & 0,0017 & 0,0017 & 100 & 0 & 0 \\
\hline Grupo & Tamanho & Desvio & Mel. ép. val. & \%Treino & \%Validação & \%Teste \\
\hline $18 \_27$ & 117 & 0,638 & 1 & 80 & 10 & 10 \\
\hline Dados & $E Q M($ treino $)$ & EQM(val.) & EQM (teste) & \%ót. (teste) & \%bom(teste) & \%ruim(teste) \\
\hline Não normal. & 0,0024 & 0,0002 & 0,0004 & 100 & 0 & 0 \\
\hline Normalizado & 0,0024 & 0,0001 & 0,0001 & 100 & 0 & 0 \\
\hline Grupo & Tamanho & Desvio & Mel. ép. val. & \%Treino & \%Validação & \%Teste \\
\hline $18 \_57$ & 622 & 0,571 & 1 & 80 & 10 & 10 \\
\hline Dados & $E Q M($ treino $)$ & EQM(val.) & EQM (teste) & \%ót. (teste) & \%bom(teste) & \%ruim(teste) \\
\hline Não normal. & 0,0024 & 0,0002 & 0,0004 & 100 & 0 & 0 \\
\hline Normalizado & 0,0024 & 0,0001 & 0,0001 & 100 & 0 & 0 \\
\hline Grupo & Tamanho & Desvio & Mel.ép. val. & \%Treino & \%Validação & \%Teste \\
\hline $18 \_74$ & 2026 & 0,633 & 1 & 80 & 10 & 10 \\
\hline Dados & $E Q M($ treino $)$ & EQM(val.) & EQM (teste) & \%ót. (teste) & \%bom(teste) & \%ruim(teste) \\
\hline Não normal. & 0,0504 & 0,0483 & 0,0479 & 96.6 & 0 & 3,4 \\
\hline Normalizado & 0,0519 & 0,0473 & 0,0467 & 96.6 & 0 & 3,4 \\
\hline Grupo & Tamanho & Desvio & Mel. ép. val. & \%Treino & \%Validação & \%Teste \\
\hline 27_30 & 100 & 0,814 & 1 & 50 & 25 & 25 \\
\hline Dados & EQM(treino) & $E Q M($ val. $)$ & EQM (teste) & \%ót. (teste) & \%bom(teste) & \%ruim(teste) \\
\hline Não normal. & 0,0433 & 0,0252 & 0,0307 & 40 & 60 & 0 \\
\hline
\end{tabular}




\begin{tabular}{|c|c|c|c|c|c|c|}
\hline Normalizado & 0,0430 & 0,0179 & 0,0246 & 40 & 60 & 0 \\
\hline Grupo & Tamanho & Desvio & Mel. ép. val. & $\%$ Treino & \%Validação & \%Teste \\
\hline 27_30 & 100 & 0,814 & 1 & 80 & 10 & 10 \\
\hline Dados & EQM(treino $)$ & $E Q M($ val. $)$ & EQM (teste) & \%ót. (teste) & \%bom(teste) & \%ruim(teste) \\
\hline Não normal. & 0,0351 & 0,0099 & 0,0150 & 40 & 60 & 0 \\
\hline Normalizado & 0,0356 & 0,0090 & 0,0147 & 40 & 60 & 0 \\
\hline Grupo & Tamanho & Desvio & Mel. ép. val. & $\%$ Treino & \%Validação & \%Teste \\
\hline 27_66 & 1070 & 0,593 & 1 & 80 & 10 & 10 \\
\hline Dados & EQM(treino $)$ & $E Q M($ val. $)$ & EQM (teste) & \%ót. (teste) & \%bom(teste) & \%ruim(teste) \\
\hline Não normal. & 0,0013 & 0,0002 & 0,0001 & 100 & 0 & 0 \\
\hline Normalizado & 0,0013 & 0,0001 & 0,0001 & 100 & 0 & 0 \\
\hline Grupo & Tamanho & Desvio & Mel. ép. val. & $\%$ Treino & \%Validação & \%Teste \\
\hline $27 \_74$ & 2079 & 0,796 & 1 & 80 & 10 & 10 \\
\hline Dados & EQM(treino $)$ & EQM(val.) & EQM (teste) & \%ót. (teste) & \%bom(teste) & \%ruim(teste) \\
\hline Não normal. & 0,0002 & 0,0002 & 0,0001 & 100 & 0 & 0 \\
\hline Normalizado & 0,0002 & 0,0001 & 0,0000 & 100 & 0 & 0 \\
\hline
\end{tabular}

Podemos observar que o aumento na quantidade dos grupos conduziu a uma melhora nos resultados, decorrente do fato que os dados dentro de um grupo tiveram redução no desvio médio, ficando assim mais similares, facilitando o treinamento da rede neural. Esta especialização é particularmente importante na fase 1 do algoritmo, qua agrupa os dados em função do comprimento das ligações entre os átomos antecessor-doador, doador_hidrogênio e da distância do hidrogênio ao centro do orbital, produzindo uma quase normalização destes dados. Este fato pode ser facilmente verificado na tabela pela semelhança entre os erros quadráticos médios e quase coincidência nas porcentagens de resultados ótimos, bons e ruins, quando comparamos os dados não normalizados com os normalizados. Porém, o aumento na quantidade de grupos gerou muitos deles com uma reduzida quantidade de padrões, o que dificulta o treinamento. Para contornar esta limitação, uma alternativa é a introdução de redundância, com réplicas dos padrões contendo um pequeno ruído, mas a implementação utilizada não contempla esta característica. Com refinamentos na quantidade de grupos, arquitetura da rede e treino com ruído para grupos pequenos, é provável que se consiga uma melhora sobre o desempenho atual. 
Vimos neste capítulo como através dos experimentos foi possível fazer-se uma evolução na metodologia com uma grande melhoria dos resultados. A configuração vizinhança esférica ou em toro, com nomeação de receptores por projeção escalar e agrupamento de dados com mapa de Kohonen apresentou taxa de erro muito alta, inadequada para uso prático. A partir de uma análise das possíveis deficiências de cada um dos componentes da configuração citada, desenvolveu-se o método de nomeação por paridade, associado ao novo algoritmo de fusão de grupos com duas fases, houve uma reversão da situação e conseguiu-se mostrar a viabilidade do uso de técnicas inteligentes para a previsão de hidrogênios em proteínas. No próximo capítulo são feitas as conclusões sobre este projeto. 


\section{Capítulo 6 Conclusão}

Os resultados obtidos dos experimentos com o uso de técnicas inteligentes para reconhecimento de padrões mostraram que estas técnicas são uma abordagem inovadora viável, alternativa aos métodos tradicionais para previsão de posição de átomos de hidrogênio em proteínas. Os métodos tradicionais apresentam alto custo computacional, enquanto que o método proposto tem o custo elevado apenas uma vez, até fazer-se o treinamento das redes neurais. Uma vez feito o treinamento, a previsão da posição feita pela rede é praticamente instantânea e de baixo custo.

Não foi encontrada na literatura nenhuma referência do uso de rede neural para a previsão da posição de átomos de hidrogênio em proteínas. Multidisciplinar por natureza, esta aplicação em bioinformática exigiu o estudo de ligações hidrogênio, estrutura e determinação de proteínas, e revisão das ferramentas existentes para a previsão de hidrogênios compreensão do contexto físico do problema; de vetores no espaço tridimensional para representação e transformação dos dados, algoritmos genéticos para alinhamento de vizinhanças, algorimos de agrupamento e modelos de redes neurais para agrupamento e reconhecimento de padrões como técnicas inteligentes para se modelar e propor um novo método para solução do problema. Várias configurações envolvendo estas técnicas foram investigadas, até obter-se o melhor modelo do problema.

O uso do modelo de rede neural MLP foi experimentado exaustivamente em muitos experimentos usando-se várias arquiteturas de rede e diferentes iniciações de seus parâmetros, com tempo de treinamento da rede neural variando de duas a quatro horas para cada experimento, executando-se até 100.000 épocas de treinamento nos primeiros experimentos, e 10.000 épocas nos experimentos documentados nesta dissertação, sem resultados satisfatórios. Esta busca pela refinamento do modelo da rede MLP que conduzisse a um acerto aceitável da previsão consumiu muito tempo do projeto e criou um dilema: o problema é muito difícil para se empregar redes neurais ou o preprocessamento dos dados estava ruim? Em função do pouco tempo restante, fez-se uma análise criteriosa das várias etapas da geração dos dados para alimentar a rede neural MLP, encontrando-se as possíveis causas de falhas em cada fase. Desta análise surgiu uma remodelagem do problema, com o desenvolvimento de métodos mais sofisticados para a nomeação de receptores dentro de uma vizinhança (algoritmo de nomeação por paridade), inclusão de um átomo âncora fictício para discriminar situações de simetria com relação ao plano contendo os átomos antecessor, doador e hidrogênio da vizinhança, do agrupamento de dados com possível não uniformidade de distribuição (algoritmo de fusão de grupo) e divisão do agrupamento em duas fases, permitindo obtenção de dados mais simétricos com relação ao 
comprimento da ligação doador-hidrogênio durante o treinamento da rede MLP. Com estas alterações na metodologia finalmente conseguiu-se validar o novo procedimento proposto. A escolha inicial de ter-se muitas redes neurais especializadas, uma para cada grupo, também foi uma decisão acertada, porque o problema de previsão é muito difícil para ser tratado por uma única rede. $\mathrm{O}$ acerto desta decisão foi observado com a melhoria obtida nos resultados dos experimentos quando se aumentou a quantidade de grupos, descrito nos experimentos da seção 5.3. O aumento da quantidade de redes neurais associadas a cada um destes grupos pode causar a impressão de inviabilizar o procedimento proposto em função do custo computacional. Precisamos considerar que o aumento na similaridade dos dados em função do aumento dos grupos, reduziu drasticamente a quantidade de épocas de treinamento, de milhares para dezenas ou unidades, para se encontrar a época de validação que produz a melhor generalização dos dados, compensando assim o aumento na quantidade de redes a serem treinadas.

O projeto ainda não está encerrado, uma vez que os experimentos atuais consideram apenas os padrões de ligações hidrogênio já contidos em um grupo. Para se poder realizar uma previsão real ainda é necessário, dados os átomos antecessor, doador e receptores, determinar qual o grupo está associado ao padrão para se usar a rede neural adequada para fazer a previsão. Só então será possível comparar a nova metodologia com as já existentes. Também é preciso estender a metodologia para aminoácidos que possuam 2 ou 3 átomos de hidrogênio nas cadeias laterais, e fazer refinamentos para se determinar a arquitetura mais adequada da rede neural e a quantidade de grupos em cada uma das duas fases do algoritmo de fusão de grupos para maximizar o potencial do novo método.

\subsection{Contribuições}

Os métodos até então conhecidos para a previsão da posição de átomos de hidrogênio utilizam-se de conhecimento do domínio químico ou físico do problema. A principal contribuição deste trabalho está na abordagem inovadora para tratar o problema de posicionamento de hidrogênios em proteínas: a combinação de várias técnicas inteligentes, como nomeação de receptores por paridade de vizinhança para estabelecimento de correspondência entre átomos de vizinhanças distintas, mapa de Kohonen ou algoritmo de fusão de grupos para agrupamento dos dados, algoritmo genético e rotações de vetores para alinhamento de vizinhanças e rede MLP para reconhecimento de padrões, permitindo que a aprendizagem de características obtidas diretamente de dados experimentais possa ser utilizada na previsão de dados que apresentem configurações similares às configurações reconhecidas e aprendidas pelas técnicas inteligentes.

Esta nova metodologia gerou um artigo apresentado no WTDIA'2006 (3rd Workshop 
on Msc Dissertation and Phd Thesis in Artificial Intelligence), quando os resultados ainda não estavam consolidados [Mancini \& Romero, 2006]. Com a evolução posterior da nova metodologia ao longo do projeto e refinamentos citados ao final introdução deste capítulo, pretende-se submeter novas publicações em outros eventos.

\subsection{Resultados}

Nesta dissertação, através dos estudos e investigações realizados, os seguintes resultados podem ser mencionados:

- o desenvolvimento de um algoritmo adequado para fazer-se a nomeação de receptores dentro de uma vizinhança, levando-se em consideração outra vizinhança com a qual deseja-se comparar;

- o desenvolvimento de um novo algoritmo para agrupamento que permite usar como entrada dados sem distribuição uniforme;

- a combinação de técnicas inteligentes integrando o agrupamento, alinhamento e reconhecimento de padrões de ligações hidrogênio;

- a validação do modelo de rede neural MLP como ferramenta adequada para o problema de previsão considerado.

\subsection{Trabalhos futuros}

Os seguintes trabalhos podem ser feitos em decorrência dos estudos apresentados nesta dissertação:

- desenvolvimento de uma rede neural que, dados os átomos antecessor, doador e receptores, faça a previsão do comprimento da ligação doador-hidrogênio, do centro e do raio do orbital do hidrogênio para que se possa determinar qual a rede neural adequada treinada a partir dos grupos deve ser usada para se fazer a previsão da posição do átomo de hidrogênio;

- estender a metodologia para o caso de aminoácidos que apresentem 2 ou 3 hidrogênios na cadeia lateral;

- estender a metodologia para a previsão de átomos de hidrogênio em cadeias de ácidos nucléicos;

- investigar se a diferenciação dos átomos receptores, em função de com quais outros átomos ele está ligado e a geometria de suas ligações covalentes (simples, dupla) influenciam nos resultados do treinamento da rede MLP; 
- investigar nos casos em que há vários receptores, se é possível fazer a exclusão de alguns deles em função da geometria, sem perda de informação signifativa para o treinamento da rede;

- estender a metodologia para trabalhar com receptores de menor eletronegatividade como carbono e enxofre (ligação hidrogênio fraca);

- experimentar treinar as redes MLP com menos redundância nos dados: como a maioria dos arquivos pdb que possuem a posição do hidrogênio são resolvidos pelo método NMR que pode conter dezenas de modelos similares da proteína, ao invés de se usar todos os modelos selecionar aleatoriamente apenas um modelo por arquivo;

- determinação da arquitetura e parâmetros iniciais mais adequados da rede MLP para o problema;

- aplicação de um esquema de validação de dados mais sofisticado ao treinamento da rede MLP, como o multifold, por exemplo; experimentar esquemas com métodos de determinação de estrutura diferentes como NMR para treino, difração por neutron para validação e cristalografia de raio-X com alta resolução para teste;

- estudo de critérios de parada do treinamento da rede neural baseados possivelmente em funções multiobjetivo para determinar a melhor generalização dos dados de validação;

- uso de modelos alternativos para o agrupamento de dados, como a rede ART, e reavaliação do mapa de Kohonen, associados com o algoritmo de nomeação por paridade de vizinhança e aplicados em duas fases: uma para a geometria das ligações antecessor-doador, doador-hidrogênio e outra para os receptores;

- uso de modelos alternativos para a previsão, como a rede RBF;

- reconhecimento de padrões de características presentes na interface de duas proteínas ligadas. 


\section{Bibliografia}

Banaszak, L. J. Foundations of Structural Biology. Academic Press, 2000.

Berman, H. M. ; Westbrook, J. ; Feng, Z.; Gilliland, G.; Bhat, T.N.; Weissig, H.; Shindyalov, I. N.; Bourne, P. E. The Protein Data Bank. Nucleic Acids Research, v. 28 , , p. 235-242, 2000.

Berry, E. A.; Dalby, A. R. ; Yang, Z. R. Reduced bio basis function neural network for identification of protein phosphorylation sites: comparison with pattern recognition algorithms.

Computational Biology and Chemistry, v. 28 , , p. 75-85, 2004.

Berthold, M.; Hand, D. J. Intelligent Data Analysis - An introduction.(2 ed.) Springer-Verlag, 2003.

Bittencourt, G. Inteligência Artificial - Ferramentas e Teorias. Cartgraf Ltda., 1996.

Braga, A. P.; Carvalho, A. P. L. F.; Ludermir, T. B. Redes Neurais Artificiais: Teoria e Aplicações. LTC - Livros Técnicos e Científicos Ed. S.A., 2000.

Dietman, S. ; Frommel, C. Prediction of 3D neighbours of molecular surface paches in proteins by artificial neural networks. Bioinformatics , v. 18 , n. 1, p. 167-174, 2002.

Duda, R. O.; Hart, P. E.; Stork, D. G. Pattern Classification.(2 ${ }^{\text {a }}$ ed.) "A Wiley-Interscience Publication", 2001.

Engler, N.; Parak, F. G. Hydrogen atoms in proteins: positions and dynamics. PNAS, v. 100 , n. 18 , p. 10243-10248, 2003.

Fabiola, F. ; Bertram, R.; Korostelev, A.; Chapman, M. S. An improved hydrogen bond potential: impact on médium resolution protein structures. Protein Science, v. 11 , , p. 1415-1423, 2002. Fariselli, P. ; Casadio, R. A neural network based predictor of residue contacts in proteins. Protein Engineering, v. 12 , n. 1, p. 15-21, 1999.

Fariselli, P.; Olmea, O. ; Valencia, A.; Casadio, R. Progress in predicting inter-residue contacts of proteins with neural networks and correlated mutations. Proteins: structure, function, and genetics , Suppl. 5 , , p. 157-162, 2001.

Fariselli, P.; Olmea, O. ; Valencia, A. ; Casadio, R. Prediction of contact maps with neural networks and correlated mutations. Protein Engineering, v. 14 , n. 11, p. 835-843, 2001.

Fariselli, P. ; Pazos, F. ; Valencia, A.; Casadio, R. Prediction of protein-protein interaction sites in heterocomplexes with neural networks. Eur. J. Biochem, v. 269 , , p. 1356-1361, 2002.

Fayos, J. ; Infantes ,L.; Cano, F. H. Neural network prediction of secondary structure in crystals: hydrogen-bond systems in pyrazole derivatives. Crystal Growth \& Design , v. 5 , n. 1, p. 191-200, 2005.

Forrest, L. R.; Honig, B. An assessment of the accuraccy of methods for predicting hydrogen positions in protein structures. Proteins: structure, function and bioinformatics, v. 61 , , p. 296309, 2005.

Glusker, J. P.; Lewis, M.; Rossi, M. Crystal Structure Analysis for chemits and Biologists. VCH Publishers, Inc, 1994. 
Gutteridge, A.; Bartlett, G. J. ; Thornton, J. M. Using a neural network and spatial clustering to predict the location of active sites in enzymes. J. Mol. Bio. , , 330, p. 719-734, 2003.

Hasegawa, K.; Matsuoka, S. ; Arakawa, M.; Funatsu, K. New molecular surface-based 3D-QSAR method using Kohonen neural network and 3-way PLS. Computers \& Chemistry , v. 26 , , p. 583589, 2002.

Haykin, S. Neural Networks - A Comprehensive Foundation.(2a ed.) Prentice-Hall, 1998.

Kohonen, T. Self-Organization and Associative Memory.(3 ${ }^{a}$ ed.) Springer-Verlag, 1989.

Kortemme, T.; Morozov, A. V.; Baker, D. An improved hydrogen bond potential: impact on médium resolution protein structures. Protein Science, v. 11 , , p. 1415-1423, 2002.

Lesk, A. M. Introduction to Protein Architecture. Oxford University Press, 2001.

Mancini, A. L.; Romero, R. A.F. Reconhecimento de padrões de pontes de hidrogênio em proteínas para previsão da posição dos átomos de hidrogênio. WTDIA, , , p. mídia em CD, 2006.

McDonald, I. K.; Thornton, J. M. Satisfying hydrogen bonding potential in proteins. J. Mol. Bio. , v. 238 , , p. 777-793, 1994.

Nelson, D. L.; Cox, M. M. Lehninger Principles of Biochemistry.(3 ${ }^{\mathrm{a}}$ ed.) Worth Publishers, 1982.

Pollastri, G. ; Baldi, P.; Fariselli, Casadio, P.; R. Improved prediction of the number of residue contacts in proteins by recurrent neural networks. Bioinformatics , v. 17, 90001, p. S234-S242, 2001.

Reed, R. D.; Marks II, R. J. Neural Smithing - Supervised Learning in Feedforward Artificial Neural Networks. "A Bradford book", 1999.

Rojas, R. Neural Networks - A Systematic Introduction. Springer-Verlag, 1996.

Russell, S.; Norvig, P. Inteligência Artificial.(2a ed.) Elsevier Ed. Ltda./Ed. Campus, 2004.

Shu, F.; Ramakrishnan, V.; Schoenborn, B. P. Enhanced visibility of hydrogen atoms by nêutron crystallography on fully deuterated myoglobin. PNAS , v. 97 , n. 8, p. 3872-877, 2000.

Torshin, I. Y.; Weber, I. T.; Harrison, R. W. Geometric criteria of hydrogen bonds in proteins and identification of 'bifurcated' hydrogen bonds. Protein Engineering, v. 15 , n. 5, p. 359-363, 2002. Turner, P. C.; McLennan, A. G.; Bates, A. D.; White, M. R. H. Molecular Biology Instant Notes. BIOS Scientific Publishers, 2000.

Westhead, D. R.; Parish, J. H.; Twyman, R. M. Bioinformatics Instant Notes. BIOS Scientific Publishers, 2002. 